\title{
"DA FORMAÇÃO DE GRUPOS À AÇÃO COLETIVA: UMA ANÁLISE COM GRUPOS DE JOVENS DO ASSENTAMENTO RURAL DA FAZENDA IPANEMA - IPERÓ-SP"
}

\section{Cristina SuARez Copa Velasquez}

Dissertação apresentada à Escola Superior de Agricultura

"Luiz de Queiroz", Universidade de São Paulo, para obtenção do título de Mestre em Ciências, Área de Concentração: Ciências Florestais.

P I R A C I C A B A

Estado de São Paulo - Brasil

Fevereiro - 2002 


\section{"DA FORMAÇÃO DE GRUPOS À AÇÃO COLETIVA: ANÁLISE COM GRUPOS DE JOVENS DO ASSENTAMENTO RURAL DA FAZENDA IPANEMA - IPERÓ-SP"}

\section{Cristina suarez COPA velasquez}

Engenheira Florestal

Orientador: Prof. Dr. MARCOS SORRENTINO

Dissertação apresentada à Escola Superior de Agricultura "Luiz de Queiroz", Universidade de São Paulo, para obtenção do título de Mestre em Ciências, Área de Concentração: Ciências Florestais.

P I R A C I C A B A

Estado de São Paulo - Brasil

Fevereiro -2002 
Dados Internacionais de Catalogação na Publicação (CIP)

DIVISÃO DE BIBLIOTECA E DOCUMENTAÇÃO - ESALQ/USP

\section{Velasquez, Cristina Suarez Copa \\ “Da formação de grupos à ação coletiva: uma análise com grupos de jovens do assentamento rural da Fazenda Ipanema - Iperó- SP" / Cristina} Suarez Copa Velasquez. - - Piracicaba, 2002.

$145 \mathrm{p}$.

Dissertação (mestrado) - - Escola Superior de Agricultura Luiz de Queiroz, 2002.

Bibliografia.

1. Ecologia (Educação) 2. Grupos sociais 3. Organização social 4. Reforma agrária I. Título

CDD 333.707

“Permitida a cópia total ou parcial deste documento, desde que citada a fonte - O autor" 


\section{DEDICATÓRIA}

Dedico este trabalho a todas as pessoas que conheci no assentamento de Iperó, na Fazenda Ipanema.

Aos pais e filhos daquela terra, que me ensinaram tanto, me recebendo sempre com muito carinho, afeto e grande compreensão. Fizeram e sempre farão parte da minha vida...

Foram tantas caminhadas largas para chegar até lá, tantas idas, tantas histórias, tanto afeto... minha outra casa...

De carro, charrete, a pé ou a cavalo, o importante era chegar, chegar em Iperó...

Aos jovens, a cada olhar brilhante cheio de esperança, de resistência, de alegria e sobretudo de amor...

Ao meu anjinho aqui na terra... Rodrigo, ser de luz e amor, carinho e compreensão incondicionais sempre, em qualquer momento da minha vida.

À minha pequenina Luísa, minha estrelinha brilhante, linda flor de amor.

À meus pais Elma e Sebastian, pelo exemplo de luta e garra nesta vida, por terem me mostrado a essência da vida.

A meus irmãos Carolina e Juan Carlos, irmãos e amigos constantes, companheiros dos meus sonhos e esperanças.

Ao nosso pequeno Tumbao, sopro de luz e ao meu cunhado e amigo, Rafael.

À Deus, grande pai de amor, fonte de luz universal. 


\section{AGRADECIMENTOS}

Agradeço ao Marcos, pela sensibilidade, pela oportunidade destas reflexões, por ter me estimulado sempre a continuar, aprendendo a acreditar. Agradeço muito pela paciência e compreensão para finalização deste trabalho.

Aos amigos-irmãos do Céu do Gamarra, fonte de exemplo, energia, de muita luz e amor. Em especial a Suzana e Fábio, aos meus queridos cunhados, grandes amigos Mari e Toy, a querida Marcela e ao Jozemar pela super-força e, aos pequeninos Pedro e Gabriel.

A Prof. Eda Tassara, Prof. Natal e Prof. Ondalva Serrano pelas contribuições importantes na minha qualificação.

A Cri e Ilza pelo carinho, apoio e grande amizade, um presente eterno na minha vida.

Ao Maciel e a Tereza que possibilitaram meu retorno ao assentamento de Iperó, contribuindo para meu amadurecimento profissional e pessoal.

Aos amigos e amigas do Laboratório de Educação e Politica Ambiental e do Departamento de Ciências Florestais que tive o prazer de conhecer e conviver, e a tantos amigos fiéis conquistados ao longo da minha vida na Esalq, que me transmitiram muita energia boa sempre: Flávia, Cremo (Flávia), Liviam \& Luís (Bibelô), Gláucia, Quares, Valéria, Marissol, Fru, Val, Renata, Adriana, Marcos (Badi), Elenara, Ilan entre tantos outros.

À querida Ada, por toda a força, apoio e amizade, fundamentais para a realização deste trabalho. Aos queridos Luciano e Rose, pessoas muito especiais, que tenho o prazer de compartir.

Aos amigos do ISA, por todo o carinho e pela força nos momentos finais deste trabalho.

Ao CNPQ, pela bolsa concedida. 


\section{SUMÁRIO}

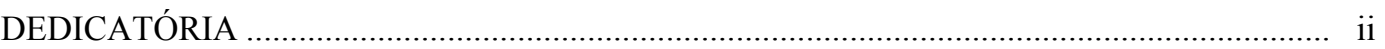

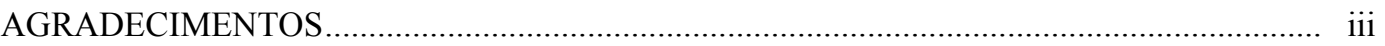

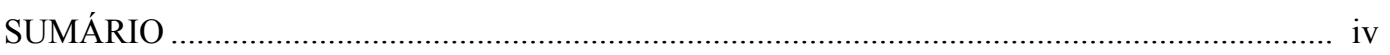

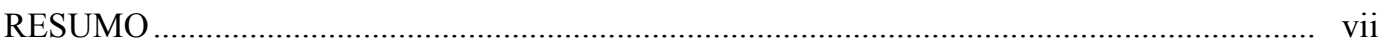

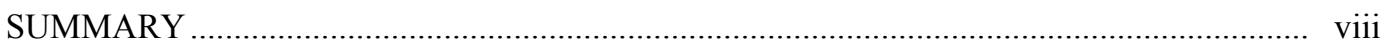

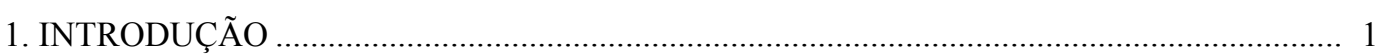

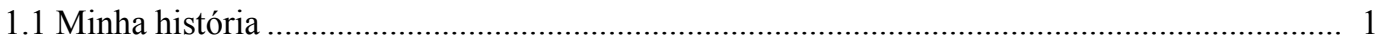

$1.2 \mathrm{O}$ contexto teórico em que surge esta dissertação ................................................................... 5

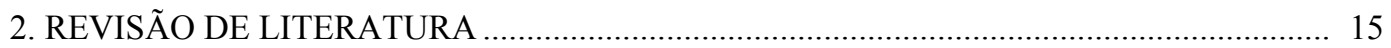

2.1 Adolescência e identidade: encontro entre vida cotidiana e privada ....................................... 15

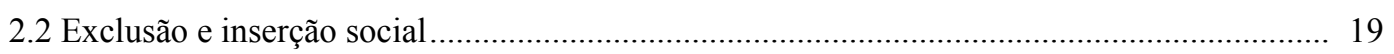

2.3 Educação Ambiental...uma utopia realista .......................................................... 23

2.3.1 A arqueologia virtual presente: um olhar diferenciado sobre a realidade ........................... 34

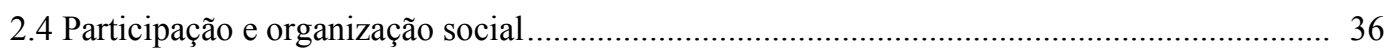

2.5 Formação de grupos e os caminhos para a ação coletiva ......................................................... 45

2.5.1. Tamanho de grupos ...................................................................................................... 47

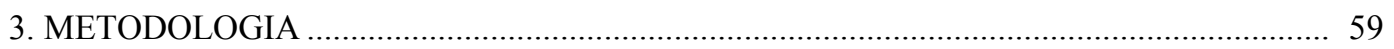

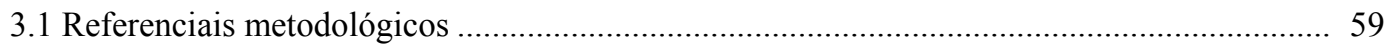

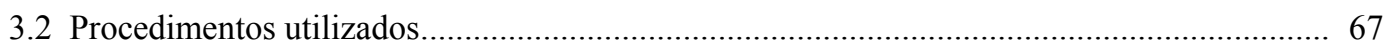

3.2.1 Procedimentos e técnicas utilizadas no TEMPO 1 ........................................................... 67

3.2.1.1 Observação participante ............................................................................................. 68

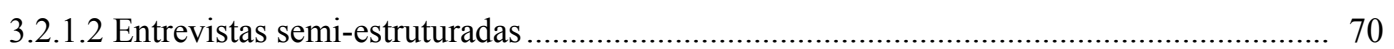

3.2.1.3 Pesquisa Documental ......................................................................................... 71

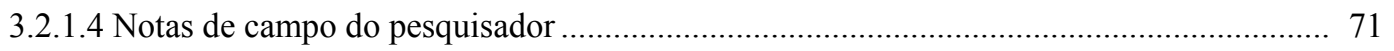

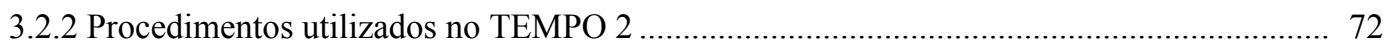

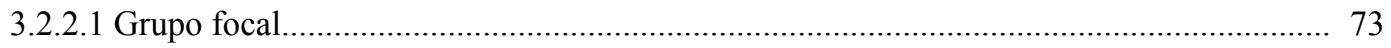

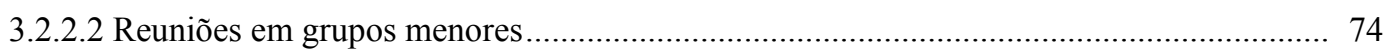

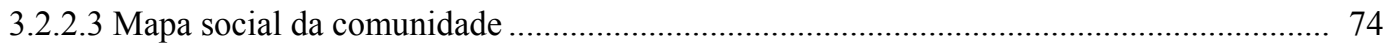

3.2.2.4 Acompanhamento dos quatro grupos menores derivados do JUMAFI 75

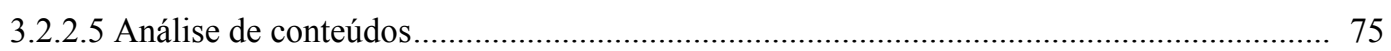

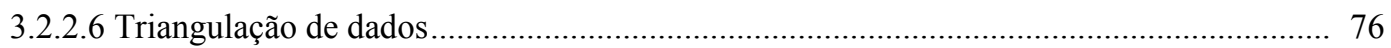




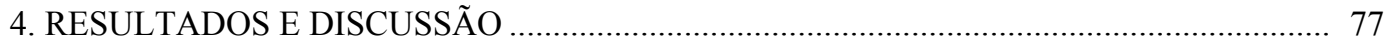

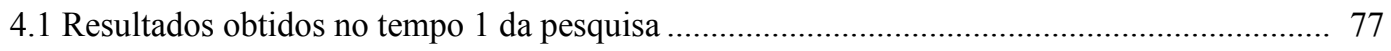

4.1.1 História do assentamento da Fazenda Ipanema em Iperó..................................................... 77

4.1.2 O processo de organização social do assentamento ............................................................ 78

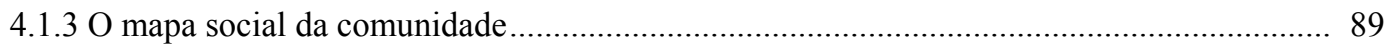

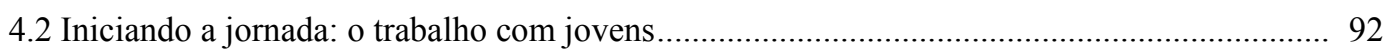

4.2.1 Preparando o grupo para a ação coletiva ........................................................................ 95

4.2.2 Caminhos incertos...mudanças de rumo ......................................................................... 97

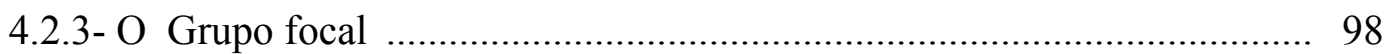

4.2.4 Considerações sobre tamanho e formação de grupos ......................................................... 105

4.2.5 Os grupos pequenos: acompanhamento e reuniões ...................................................... 113

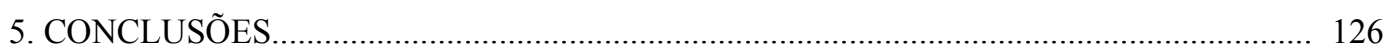

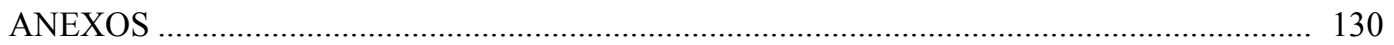

REFERÊNCIAS BIBLIOGRÁFICAS …………………………………………………..... 145 


\title{
"DA FORMAÇÃO DE GRUPOS À AÇÃO COLETIVA: UMA ANÁLISE COM GRUPOS DE JOVENS DO ASSENTAMENTO RURAL DA FAZENDA IPANEMA - IPERÓ-SP"
}

\author{
Autora: CRISTINA SUAREZ COPA VELASQUEZ \\ Orientador: Prof. Dr. MARCOS SORRENTINO
}

\section{RESUMO}

O objetivo principal dessa dissertação foi analisar o processo de formação do JUMAFI (Jovens Unidos para a Mobilização da Fazenda Ipanema), grupo de jovens do assentamento rural da Fazenda Ipanema, localizada no município paulista de Iperó, motivados pela busca a alternativas de geração de renda ambiental e socialmente sustentável, sob a luz da Educação Ambiental. Deste modo, concluí ser necessário construir uma análise a partir de uma visão de complementaridade de ações, da compreensão da lógica da ação coletiva dos grupos sociais existentes na comunidade e de uma análise comportamental sobre as iniciativas e a história de formação dos grupos locais, das experiências coletivas vividas pelos agricultores, e, principalmente, através da experiência vivida pelos jovens na organização do JUMAFI. Centrei minha análise na noção de participação e organização social, analisando a formação dos grupos e os aspectos da vida cotidiana. Utilizando elementos da pesquisa social qualitativa, e outros procedimentos da pesquisa participante, realizei o acompanhamento no desenvolvimento destes grupos, a fim de apreender os elementos que favorecem ou impedem a ação coletiva em grupos de jovens, buscando perceber as fortalezas e oportunidades vistas por eles no trabalho coletivo. 
Esta pesquisa esteve dividida em dois momentos: Tempo 1- que se refere ao momento da observação participante e de entrevistas, em que se deu o contato com os jovens do assentamento, o início do envolvimento, a formação do grupo JUMAFI e, também, todo o planejamento das ações do grupo; e Tempo 2 - momento de acompanhamento do desenvolvimento do grupo JUMAFI, momento da ação dos jovens, da gestão das idéias, a fim de colocar em prática as atividades planejadas. No momento 1 da pesquisa, o grupo grande (JUMAFI) demonstrou grande dificuldade em lidar com o trabalho coletivo, em colocar em prática o planejamento da atividades previstas para o grupo, assim como em manter a convivência e a freqüência nos encontros entre os membros do grupo. Aspectos como confiança, afetividade, afinidade e respeito foram elementos identificados por eles como fundamentais para o êxito de um trabalho dessa natureza. No segundo momento da pesquisa, embora o grupo JUMAFI tenha optado por continuar o trabalho para a busca de alternativas de geração de renda, foi dada ênfase a um novo formato, através de grupos pequenos de afinidade e convivencialidade. Concluindo, foi possível perceber que o tamanho do grupo e os aspectos de convivencialidade têm uma forte influência nos aspectos de formação, organização e gestão do espaço coletivo, bem como a forma com que os indivíduos percebem a natureza e estabelecem seus vínculos de respeito e afeto. O trabalho com jovens e o formato pequeno de grupos favorece a participação em grupo, proporciona um senso de responsabilidade maior pelo trabalho, favorece a organização voluntária, os laços afetivos e de troca, havendo espaço para uma participação mais democrática, favorecendo a autonomia dos participantes e a formação de novas lideranças na comunidade. Os grupos se organizam para a auto-expressão, possibilitando maior troca entre os integrantes e maior franqueza nos sentimentos ligados à participação coletiva. Além disso, esse tipo de organização pode, futuramente, favorecer a ação articulada junto à comunidade, permitindo uma atuação em rede. $\mathrm{O}$ arranjo metodológico, utilizando elementos da pesquisa participante e da pesquisa qualitativa, favoreceu a participação dos jovens, possibilitando maior expressão dos participantes em relação à pesquisa. Tendo em vista estes resultados, refleti ainda sobre o papel da intervenção social em trabalhos de Educação Ambiental, concluindo que estas intervenções devem estar apoiadas em um referencial teórico elaborado com base nas necessidades sentidas em campo, podendo ser o caminho para a implementação de um processo educativo continuado e não apenas uma 


\section{"From groups formation to collective actions: an analysis with groups of teenagers from the rural sitting on the Ipanema Farm - Iperó - SP"}

Author: CRISTINA SUAREZ COPA VELASQUEZ

Adviser: Prof. Dr. MARCOS SORRENTINO

\section{SUMMARY}

The main aim of this dissertation was analyzing the process of formation of the JUMAFI (Teenagers United for the Mobilization of the Ipanema Farm), group of teenagers from the rural sitting on the Ipanema Farm, located in the city of Iperó, in São Paulo state, motivated by the search for alternatives of environmentally and socially sustainable income generation, under the light of the Environmental Education. Thus, I concluded that there is a necessity of building an analysis from a starting view of complementing of actions, from the comprehension of the logics of collective actions from social groups in the community and from a behavioral analysis about the initiatives and the history of the local groups' formation, the collective experiences and, mainly, through the experience gathered by the teenagers in the organization of the JUMAFI. I centered my analysis in the notion of social participation and organization, analyzing the groups' formation and the aspects of daily life. Using elements from the qualitative social research, and other procedures of participative research, I performed the attendance in the development of these groups, for collecting the elements that favor or prevent the collective action in groups of teenagers, seeking to realize the strength and opportunities seen by them in the collective work. This research is divided in two parts: Part 1 - referred to the participative observation moment and interviews, when there was a contact with the teenagers from the sitting, the beginning of the involvement, the formation of JUMAFI and, also, all the group's action planning; and Part 2 - moment of attendance of the JUMAFI development, moment of the teenagers' action, of the ideas management, for putting into practice the planned activities. On the first part, the large group (JUMAFI) showed great difficulty in dealing with the collective work, in putting into practice the planned activities for the group, likewise keeping the living together and the frequency on the meetings between the members of the group. Some 
aspects like confidence, affectivity, affinity and respect were the elements identified by them as fundamental for the success of a work like that. On the second part of the research, though JUMAFI group has decided to keep the search for income generation activities, there was an emphasis to a new format, through small groups of affinity and living together. Concluding, it was possible to notice that the group size and the living together aspects have a strong influence on the formation, organization and collective space management aspects, like the way the individuals notice the nature and establish their ties of respect and affection. The work with groups of teenagers and the small groups format favor the group participation, provide a stronger sense of responsibility at work, favor the voluntary organization, the affective ties and changing, making room for a more democratic participation, favoring the participants autonomy and the formation of new leaderships in the community. The groups organize themselves for the self-expression, allowing a greater changing among the participants and a higher level of frankness about the feelings connected to the collective participation. Besides, this kind of organization can favor the articulate action at the community level, allowing a network action. The methodological arrangement, using elements of the participative and qualitative research, favored the teenagers' participation, allowing a bigger commitment of the participants to the research. Having in mind these results, I reflected about the role of social intervention in Environmental Education works, concluding that these interventions must be supported by a theoretical referential, elaborated based on the field necessities, being the way for the implementation of an educational process and not only a punctual intervention in field. Finally, I conclude that the Environmental Education, based on a practical and theoretical basis, can be the area of knowledge able to contribute effectively for the process of autonomy and management for groups of teenagers in search of opportunities on the rural, social and environmental sustainable field. 


\section{INTRODUÇÃO}

\subsection{Minha história}

Iniciarei com algumas reflexões a respeito de minha trajetória de vida e dos diversos caminhos que me fizeram chegar até aqui.

Nasci em São Paulo no dia 14 de agosto de 1970.

De minha vida toda, a influência da vida de meu pai é a que mais me emociona, ex-guerrilheiro boliviano, do exército de justiça de Che Guevara.

Minha família é boliviana. Há portanto, todo um acúmulo de tradições e conhecimentos culturais transmitidos de pais para filhos, e que permanecem vivos.

$\mathrm{Na}$ memória, as lembranças e o olhar de meu pai misturaram sentimentos de dor e esperança na busca por um mundo melhor e mais justo. Para mim, o reflexo de tudo isso veio mais tarde com incursões no meio político, científico e religioso.

Uma sensação de despatriamento e a vontade de mudar o mundo foram companheiros na caminhada adolescente. Mais tarde, com a vinda de minha filha Luísa, o desejo de mudança veio acompanhado de compreensão e tolerância.

A Universidade surgiu em minha vida como possibilidade de buscar um sentido concreto às inquietudes do espírito, ao incômodo gerado pelas injustiças sociais e pela exclusão social.

Durante a graduação, percorri diferentes caminhos, buscando encontrar uma trilha, um 'sendero' que me trouxesse respostas. A floresta e as populações que vivem ao seu redor apareciam como meio para combater a pobreza e exclusão social, mas também como vítima dos caminhos destas injustiças sociais. A floresta que eu me propus a estudar, era viva, de genes e espécies nativas, de mitos, de espíritos, de sons, capazes de traduzir vida e de transformar vidas.

Esta busca surgiu primeiro como necessidade própria de compreender a relação do ser humano com a natureza, depois, como forma de proporcionar esta compreensão a outros, principalmente àqueles que estavam diretamente envolvidos com o uso dos recursos naturais. 
Crescia meu interesse por estudar e aprofundar meu conhecimento a respeito das comunidades que vivem e dependem diretamente dos recursos naturais como forma de vida.

Participei, nesta época, de diferentes projetos na área de conservação ambiental, com o intuito de compreender melhor a sua relação com o desenvolvimento humano.

E foi neste contexto, em 1994, que a oportunidade de investigar o tema surgiu de maneira real, através dos agricultores sem terra, da Fazenda Ipanema em Iperó, São Paulo, que, por viverem no entorno de uma área protegida, necessitavam reestabelecer a sua relação com a floresta.

Na década de 90, o movimento de reforma agrária viveu um momento marcante no Brasil, marcado por grandes lutas e bandeiras. As reivindicações sociais e a mobilização popular retomavam forças através de uma causa legítima, quase secular, causadora de conflitos fatais neste país, p. a luta pelo direito a terra.

Foram grandes ocupações de terra, aumento da pressão em torno da criação e reconhecimento de assentamentos rurais em diferentes lugares do Brasil, a forte resistência dos agricultores, verdadeira luta de ex-propriados da terra.

Esse movimento questionador e proponente buscava respostas e caminhos para expressar sua luta. As universidades de ciências agrárias, ou uma pequena parte delas, foram antigas parceiras nesta causa.

A ESALQ, no ano de 1992, havia sido procurada por um grupo de assentados da Fazenda Ipanema, para discutir e contribuir na resolução do difícil conflito enfrentado pelos assentados, p. a necessidade concreta de apresentar um projeto de manejo florestal como contrapartida para a permanência na terra. Vizinhos de uma unidade de conservação recém-decretada, a Floresta Nacional de Ipanema, pairavam sobre eles muitas dúvidas em relação ao enfrentamento desta nova situação.

Fruto desta demanda estabeleceu-se uma relação entre universidade e comunidade, representada por professores e alunos daquela escola, dispostos a estudar e contribuir com o desenvolvimento daquele local e os representantes da coordenação do assentamento rural da Fazenda Ipanema. Após um período de negociações, surgiu o GEAR-IPERÓ, Grupo de Estudos em Assentamentos Rurais da Fazenda Ipanema-Iperó, SP. 
Meu envolvimento direto se deu a partir de 1994, buscando compreender aquela realidade, estabelecendo relações, contribuições técnicas em manejo florestal e viveiros de mudas, mas principalmente aprendendo.

As primeiras visões dos barracos feitos de embalagens tetrapack representavam um re-começo nas vidas daquelas pessoas. As incertezas, a esperança e a coragem estampada na face de toda aquela gente, além da luta travada cotidianamente pela sobrevivência, tomou-me pelas mãos.

Sentia a necessidade de compreender um pouco melhor a estrutura que permeava a formação social daquele grupo de pessoas, bem como, as estratégias por eles utilizadas. Afinal, estavam vivendo um momento posterior, o da conquista da terra.

Entender a condição dos sem - dos sem-terra, sem-casa, sem-comida, dos desterrados - era, para mim, um grande objetivo. A necessidade de ouvir as diferentes histórias dos agricultores, das mulheres, da agricultura, das políticas de reforma

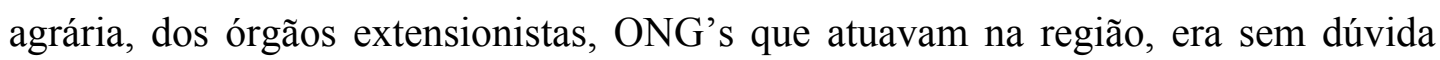
uma necessidade a ser preenchida, antes de iniciar concretamente uma intervenção ou estudo técnico específico.

A vivência possibilitada pelas visitas às casas dos agricultores, pela participação em reuniões nos grupos de jovens, de mulheres, nas reuniões do conselho e pela construção e estabelecimento de uma relação de confiança entre os assentados, foi essencial para compreender a dinâmica interna dos grupos.

Com a ESALQ-USP através do GEAR-Iperó, foram desenvolvidos estudos, vivências e teses acadêmicas de diagnóstico e caracterização da comunidade, entre outros.

A partir daí, em 1997 surgiu à possibilidade de dar continuidade a um trabalho no assentamento, através do convite de dois pesquisadores, que iam desenvolver suas teses de mestrado e doutorado no assentamento.

Eram pessoas de fora, com um olhar novo, diferente e uma experiência também diferenciada. Veio o convite para contribuir no trabalho com o grupo de jovens, que estava sendo mobilizado pela pesquisadora de doutorado. Apesar de ser uma experiência nova, trabalhar com jovens, me parecia bastante instigante. 
Iniciamos então, o trabalho de formação de um grupo de jovens no assentamento, pois o objetivo era o de conhecer e estudar a identidade destes jovens.

A juventude rural no assentamento passava por grandes dificuldades, a falta de alternativas e opções de geração de renda atingia a todos de maneira direta e as angústias da vida adulta começavam a aparecer. Os problemas ligados a alternativas na terra, as dificuldades de estudo e o futuro incerto eram marcas deste momento de transição na vida destes jovens.

$\mathrm{O}$ olhar psicológico da pesquisadora contribuiu para que eu enxergasse um outro caminho, uma nova e diferente forma de perceber as minúcias cotidianas, o papel social que os jovens desempenhavam na comunidade, na casa, na roça.

Conquistar a confiança do grupo, essencial para sua formação, foi o primeiro passo. Considero que este foi um trabalho intenso e difícil, porém muito significativo, em que tive que apreender muito da vida cotidiana destes jovens, de seus pais, reconquistar a relação de confiança necessária para a evolução dos trabalhos, exercitar a observação e ir montando um quebra-cabeça, que penso estar constantemente em construção.

A conclusão de que a realidade social é bastante complexa, torna necessária a elaboração de um referencial teórico mais apurado, muito se devendo ao entrecruzamento teoria e prática, ultrapassando, por vezes, os limites do campo de formação reservado a uma Engenheira Florestal. Trabalhar com adolescentes, em um contexto como este, exige, muitas vezes, uma gama de outras habilidades sociais.

É neste caminho de busca e compreensão teórica, que refleti sobre os processos de formação de grupos, trabalhos com jovens e também sobre as intervenções sociais em comunidades rurais.

Trago estas reflexões para esta dissertação de mestrado, como um ensaio de reflexões e ações sobre o tema.

No encontro entre a minha história de vida, o assentamento rural e as reflexões acadêmicas que permearam esta realidade social, é que buscarei dialogar.

\section{$1.2 O$ contexto teórico em que surge esta dissertação}


O planeta necessita, em todos os sentidos, de compreensões mútuas. Dada a importância da educação para a compreensão, em todos os níveis educativos e em todas as idades, o desenvolvimento da compreensão necessita da reforma planetária das mentalidades; esta deve ser a tarefa da educação do futuro".

(Morin, 2001, p.104)

Um número imenso de pessoas em todo o mundo é vítima de várias formas de privação de liberdade. Fomes coletivas, pouco acesso a serviços básicos, como saúde, saneamento, água, segurança econômica e social, moradia e terra, reduzem a participação social, sendo negados a liberdade política.

A visão de liberdade envolve tanto processos que permitam a liberdade de ações e decisões, como as oportunidades reais que as pessoas têm, dada às circunstâncias pessoais e sócio-ambientais em que vivem.

Trata-se, portanto, de dialogar, preocupando-se com o fato de que, algumas pessoas desfavorecidas sofrem privação sistemática de oportunidades substantivas, ou seja, oportunidades que atendam as necessidades reais de um grupo social, tendo acesso apenas a oportunidades adequadas, ou seja, aquelas que não necessariamente estão de acordo com os desejos das pessoas, tendo, portanto, que ser adequadas a circunstâncias colocadas (Sen, 2000).

Há que se ter condições econômicas e, principalmente, políticas favoráveis, a partir de oportunidades substantivas, possibilitando opções de escolha.

De acordo com o PNUD (1990) citado por Demo (2001:170) o desenvolvimento humano é definido como oportunidade, valorizando, acima de tudo, a capacidade de intervenção das pessoas ou sua competência política.

Ficando relevante a situação preocupante da pobreza política brasileira. Demo (op.cit., p. 170) menciona que, em função disso, o nosso indicador mais fundamental de desenvolvimento passaria a ser educação, seguido de longevidade e somente em terceiro lugar o poder de compra.

Neste sentido, as oportunidades substantivas valorizadas devem ser aquelas que priorizam o bem comum, os valores sociais, os direitos básicos da cidadania enquanto estratégia prioritária.

Paralelamente, a escolha que determinado indivíduo ou grupo social fará frente às oportunidades existentes, dependerá de diversos fatores, como a 
'ambiência' ou condições externas que possam favorecer esta tomada de decisão, além de condições internas, como a pré-disposição para aceitar determinada situação, além da capacidade reflexiva para compreender o que lhe apresentado enquanto oportunidade.

O conceito de ambiência refere-se não só a forma com que as pessoas percebem o ambiente externo - o local onde vivem, a casa, a roça, o grupo social; a relação com o outro e com a natureza - mas também à maneira como são estabelecidas entre elas as relações interpessoais, como o respeito, a confiança e o cuidado.

Estes fatores favorecerão a cooperação espontânea, a dedicação e a priorização desta enquanto oportunidade real para os indivíduos e para o coletivo maior.

Maffesoli (1997) acredita que a ambiência englobante determina profundamente as atitudes individuais, os modos de vida, as maneiras de pensar, e as diversas inter-relações sociais, econômicas, políticas, ideológicas, religiosas, constituindo a vida em sociedade.

Isso nos leva a refletir sobre a necessidade de compreender estes fatores ao se projetar trabalhos sócio-ambientais com grupos.

Digo isto, pois o estudo que se reflete agora nesta dissertação esteve baseado no acompanhamento e desenvolvimento do processo de formação de grupos de jovens do assentamento rural da Fazenda Ipanema em Iperó - SP, como também na busca de alternativas para a geração de renda com estes jovens.

Durante a realização da presente pesquisa, todos os elementos mencionados acima como a ambiência, a cooperação, a dedicação e o desenvolvimento do trabalho em grupo foram o rumo na busca das oportunidades substantivas para estes jovens.

Captar e analisar estes elementos tornou-se o fio condutor deste trabalho, que buscou compreender como contribuir responsavelmente com grupos sociais através do enfoque da cotidianidade e da formação e desenvolvimento dos grupos de jovens.

Dentro deste cenário, duas perguntas-chave foram impulsionadoras para $\mathrm{o}$ desenvolvimento deste trabalho. Uma mais ligada aos aspectos de formação e tamanho de grupos e outra com enfoque para o questionamento da própria intervenção nos trabalhos em Educação Ambiental. São elas: 
Como contribuir para que os trabalhos de intervenção em Educação Ambiental ${ }^{1}$ tornem-se oportunidades substantivas para grupos comunitários?

Como se dá o processo de formação de grupos de jovens assentados, na busca de alternativas de geração de renda, ambiental e socialmente sustentáveis?

A proposta básica, nesse sentido, foi à análise do processo de formação de um grupo de jovens dentro do assentamento, além da busca por oportunidades reais de melhoria de sua condição de vida.

Propus o desenvolvimento do trabalho naquele local, de universo específico, onde a relação homem/natureza está fortemente marcada, seja através de um passado longínquo ligado a terra, seja por um reencontro com a natureza, permeado por uma convivência cotidiana algumas vezes conflituosa.

Trata-se de um grupo social recente, que se formou em uma situação de grande heterogeneidade. Convivem ali diversos modos de vida, profissões, padrões culturais, hábitos distintos e como era de se esperar diferenciadas formas de perceber a natureza.

A forma com que os indivíduos percebem a natureza e estabelecem seus vínculos de respeito e afeto influencia tremendamente as atitudes e as tomadas de decisão frente às oportunidades que possam surgir em seu meio.

Deste modo, ao desenvolver este trabalho, concluí ser necessário construir uma análise a partir de uma visão de complementaridade de ações, da compreensão da lógica da ação coletiva dos grupos sociais existentes na comunidade e, de uma análise comportamental sobre as iniciativas e a história de formação dos grupos locais.

Optei por realizar uma pesquisa social qualitativa a partir da experiência anteriormente vivida com estes atores e da análise do grupo de jovens através da ótica da Educação Ambiental.

Centrei minha análise na noção de participação e organização social, analisando a formação dos grupos e os aspectos da vida cotidiana.

O desenvolvimento desta análise é essencial, uma vez que, intervenções educacionais podem contribuir tão somente para uma participação pontual, que dura

\footnotetext{
${ }^{1}$ Utilizarei durante o transcorrer deste trabalho a abreviação EA para o termo Educação Ambiental.
} 
o tempo em que o agente externo está presente em campo podendo raramente evoluir para o desenvolvimento de processos co-participativos que podem ser continuados, e finalmente apropriados pelos atores locais envolvidos.

Sob o ponto de vista dos atores locais envolvidos, acredito que a participação é a base de sua percepção na visualização das diferentes oportunidades que possam existir em seu meio.

A educação pode ser um caminho para a percepção não só do ambiente a sua volta, mas também das possibilidades que daí podem emergir. O desenvolvimento de um olhar diferenciado em relação ao local e o reconhecimento deste enquanto possibilidade, enquanto oportunidade, gera força, potência e com isso a possibilidade de transformar o que se tem em mãos.

Dentro desta ótica, a Educação Ambiental pode representar um caminho na busca de uma educação emancipatória, mais autônoma e potencializadora de ações.

De acordo com Sawaia (1999), devido ao excesso de instrumentalização e normatização a que muitos grupos sociais foram, de certa maneira, aprisionados, torna-se necessário, agora, potencializá-los, ou seja, proporcionar-lhes 'potência à ação’. Em outros termos, significa a necessidade de atuar, ao mesmo tempo, na configuração da ação, da significação, bem como no campo das emoções coletivas e individuais:

" realça o papel positivo das emoções na educação e na conscientização, que deixa de ser fonte de desordem e passa a ser visto como fator constitutivo do pensar e agir racionais" ( Sawaia,1999, p.111).

Torna-se, portanto, necessário não só compreender a natureza dos processos que geram as oportunidades, mas também investigar a liberdade de escolha que as pessoas têm frente a elas, assim como as possibilidades de potencializar as ações coletivas e/ou individuais.

Persegui a trilha na busca da valorização da experiência pessoal conformada pelos costumes e tradições que contribuem para formar a identidade e traduzir, em muitos casos, o comportamento de indivíduos e de grupos, passando principalmente, por uma análise do cotidiano.

Influenciada por Michel Maffesolli e José de Souza Martins, vejo na análise do cotidiano a importância e a necessidade de se compreender os fatos e as 
definições de rumos, através das suas manifestações mais espontâneas. A fidelidade com que os sentimentos mais sinceros são expressos nas atitudes e ações da vida cotidiana, é que vai ser a 'matéria-prima' a partir da qual a pesquisa social se constrói.

Para alguns autores, estas manifestações são aparentemente pouco expressivas, pouco representativas das situações mais concretas da vida e até, acreditam alguns, ofuscam a investigação científica, contribuindo para a perda da visão institucional no conjunto.

Acredito justamente no contrário, pois a análise em escala microssocial nos dá a possibilidade de examinar os mecanismos de reprodução das relações sociais, ao mesmo em que nos permite analisar inclusive as contradições existentes na vida cotidiana dos atores envolvidos.

Vale lembrar que, boa parte das críticas dirigidas ao estudo da cotidianidade referem-se a uma interpretação equivocada a respeito de sua abrangência. Consideram que o conceito cotidianidade está ligado à prática de investigação na esfera da vida privada.

A proposta defendida por Martins e Maffessoli considera não apenas as relações interpessoais ou aspectos da vida social como elementos de análise, mas sobretudo objetiva interpretar a relação entre diferentes elementos existentes na cotidianidade.

Sob esse prisma, analisamos a cotidianidade fortemente influenciada pelo mundo globalizante, ou seja, pelo cotidiano massificador, gerando um processo de criação de instrumentos de coisificação das pessoas, da globalização de tudo e de todos. Portanto, o conceito, aqui utilizado, diferencia-se de uma análise unicamente enfocada na vida privada, pessoal e particular dos sujeitos em questão.

A vida cotidiana, assim analisada, é capaz de trazer como resultado uma verdadeira negação ou proibição da vida privada. Parafraseando Martins (1997, p.157) "o aparecimento da cotidianidade é a transformação da realidade social numa realidade de manipulação, de escamoteamento, de alienação moderna, alienação levada ao extremo de suas possibilidades, de mistificação da vida".

Martins (op. cit., p. 159) nos traz a nítida diferença na definição da análise cotidiana. 
"Há um enorme desencontro entre vida cotidiana e vida privada, é necessário separar as duas coisas. Na verdade a vida cotidiana pensada a partir da cotidianidade - numa era, como esta, dominada pela vida cotidiana - nega a vida privada. É exatamente o oposto da vida privada no sentido de que a vida privada implica no reconhecimento do indivíduo, da individualidade, dos direitos pessoais, do cidadão. A vida cotidiana é a negação de absolutamente tudo isso. Ela homogeiniza, manipula, coisifica e assim por diante"

No entanto, acredito que é neste mesmo cotidiano que podemos identificar as ferramentas para a compreensão da realidade social dos atores envolvidos. Uma compreensão que comporta o conhecimento mais humano e intersubjetivo, menos objetivo e explicativo (Morin, 2001, p. 94).

A utilização de procedimentos metodológicos, como a aplicação de questionário, ou mesmo a entrevista semi-estruturada, dependendo do objetivo da pesquisa, se utilizados isoladamente, podem fornecer dados parciais sobre a realidade analisada. Isso porque, corre o risco de induzir a uma situação artificial. Ao passo que, a utilização de diferentes procedimentos com enfoque na análise do cotidiano, poderia fornecer melhores resultados.

Além disso, baseada nas concepções defendidas por Santos (1995), acredito que é fundamental promover uma escavação sobre a realidade social, buscando trazer à tona questões que de outra maneira ficariam escondidas. Para Maffessoli (1997), a análise do cotidiano é justamente um meio para se realizar a escavação da realidade social.

Alguns outros autores contribuem para reforçar esta idéia, afirmando que a análise do cotidiano pode ser definida como a miniatura dos aspectos da socialidade. (Maffessoli, 1997; Berger, 1998; Martins, 1997; Teixeira, 1990).

Na década de 70, em várias partes do mundo, esta preocupação já despontava dominando o contexto histórico. Martins (1997) cita a rebelião juvenil de 1968, como um exemplo desta explosão contida na vida cotidiana dos jovens, repleta de expressão.

Historicamente, logo após a segunda guerra mundial, Henry Lefebvre, citado por Martins (1997), foi quem propôs que os marxistas começassem a se preocupar com a vida cotidiana, porque a vida cotidiana estava se transformado no instrumento 
de bloqueio das possibilidades de transformação da sociedade em uma sociedade nova e justa.

Teixeira (1990) citando Maffessoli coloca a importância do enfoque voltado para as múltiplas e minúsculas situações e práticas da cotidianidade, traz o lado sombra do social, onde se dá a conservação de cada indivíduo da espécie. É aquilo que foge da razão, que escorre pelas mãos, e que traz a essência e a ordem na aparente desordem social.

A fim de expressar minhas observações sobre a análise do cotidiano, refletirei sobre o que, neste trabalho, chamarei de "as portas de entrada na comunidade", que podem ser mais bem compreendidas quando se tem clareza prévia das forças sociais que interagem naquele lugar, das regras e normas informais que vigoram regendo e determinando aspectos da vida social como se fossem a alma do corpo social ou como denomina Maffesolli o 'lençol freático’ de toda a vida social.

De acordo com esta perspectiva e como mencionado anteriormente, optei por desenvolver o trabalho com jovens junto ao assentamento rural da Fazenda Ipanema, pois havia um envolvimento meu com esta comunidade desde 1994 através do Grupo de Estudos em Assentamentos Rurais GEAR-Iperó².

Assim, esta dissertação tem por objetivo principal compreender e analisar como se dá o processo de envolvimento, organização e participação de grupos de jovens assentados, motivados pela busca de alternativas de geração de renda ambiental e socialmente sustentáveis, fornecendo elementos que possam orientar futuras intervenções comunitárias.

O trabalho parte de um universo complexo, apresentando como necessárias às incursões em diferentes áreas do conhecimento, como a questão fundiária, o problema da juventude rural e o movimento social de luta pela terra, a questão ambiental e a sustentabilidade e o ambientalismo. Temas como a exclusão e inclusão social, o conceito de participação, processos educativos e organização social de grupos, considerando sempre a vida cotidiana no caminho da investigação científica, formaram o arcabouço teórico utilizado.

\footnotetext{
${ }^{2}$ GEAR-Iperó: Grupo de estudos em assentamentos rurais, assentamento de Iperó-SP. Constituído por um grupo de estudantes e professores da ESALQ preocupados e envolvidos com a questão agrária e sócio-ambiental dos assentamentos rurais no estado de São Paulo.
} 
No estudo destes temas, busquei captar interpretações distintas, porém complementares, o que possibilitou um exercício de bricolagem: a multirreferencialidade ${ }^{3}$.

Busquei reconhecer e distinguir as diferentes óticas e linguagens dos jovens, para, a partir destas percepções, chegar a formulação de reflexões teóricas.

A metodologia aqui adotada é a da Pesquisa social qualitativa com enfoque na educação ambiental. Tornou-se necessário, multirreferenciar, buscar fontes diversas, a fim de responder a perguntas antigas que foram se modificando ao longo destes anos da ciência, clamando por outras vozes e maneiras diferentes de explicar suas inquietudes, buscando dar voz ao diálogo mudo que se instaurou na relação entre as dimensões erudita e popular.

Neste sentido, há uma passagem de Sawaia (1999, p.97) bastante ilustrativa desta relação.

"A ciência sempre avançou pela dúvida e pelas perguntas, as quais mudam de qualidade nos diferentes contextos históricos. Hoje a novidade é que elas não são mais feitas para obter informações e sim por excesso de conhecimento, aos quais Souza Santos (1997, p.117) determina de 'interrogações poderosas', são as contrahegemônicas, capazes de penetrar nos pressupostos epistemológicos e ontológicos do saber constituído, como as indagações que unem ciência e virtude introduzindo a ordem do valor e da ética nos conceitos científicos".

Em trabalho anterior, a mesma autora menciona que..." $a$ utopia é a força motriz de todo ato revolucionário, e a cientificidade e a racionalidade tem matado a utopia” (Sawaia, 1987, p.69).

Gostaríamos de compartilhar da utopia que nos moveu todo esse tempo, que foi o pano de fundo a partir da qual fomos descobrindo os caminhos.

Trata-se da paixão pelo tema, pela vida e luta dessas pessoas, pela liberdade a que todos nós aspiramos e que muitas vezes está empoeirada, esquecida, coberta por um pó denso, escuro, e que na singularidade das análises convencionais muitas vezes passa despercebida. É a fala muda, o desejo sem luz, a des-esperança, o des-

\footnotetext{
${ }^{3}$ A abordagem multirreferencial, para além das teorias unitárias, está atrelada ao balizamento preliminar que liga o pesquisador, individual ou coletivo, ao seu campo e ao seu objeto. (Ardoino, 1998). Para Colon (1998, p.150) "a multirreferencialidade pressupõe combinar várias abordagens, recorre a conceitos de procedência heterogênea, de fontes diversas, $p$. é uma noção que se alimenta dos modos de pensar das diferentes disciplinas, procedimentos paradigmas".
} 
enraizamento, enfim, o ser des-terrado que por não poder falar, muitas vezes é refém e também reprodutor das relações de dominação há tanto tempo estabelecidas e reproduzidas no nosso processo de socialização.

Falamos de uma paixão vibrante, que partilhou momentos, que apreendeu, que viveu para sentir. Não se trata de uma paixão cega, e sim como coloca Sawaia (1987) da paixão defendida por Weber na atividade científica "a paixão emulativa, obsessiva, que estimula, engaja, sem anular a criticidade”, a paixão que permite sentir as emoções elementares de um povo.

\section{- A Dissertação}

A presente dissertação foi organizada da seguinte forma:

No Capítulo 2 - "Revisão de literatura", o pano de fundo para a discussão dos objetivos do trabalho. Pautado na compreensão da relação entre desenvolvimento e ambiente (Sen, 2000) e nas discussões das idéias de Maffesoli (1997) e Martins (1997) possibilita entender a sociologia como conhecimento de uma socialidade ligada à vida e a experiência da cotidianidade. Às concepções desses autores soma-se as de Santos (1995), sobre o processo de transformação social, colocando em cheque nosso modelo civilizacional, a transição e a pós-modernidade, a organização social e a valorização de uma eco-utopia. Rey (1999) e Sawaia (1987, 1997, 1999 e 2000) nos remetem a reflexões teóricas sobre os diferentes tipos de metodologias para a compreensão de dois elementos fundamentais para o desenvolvimento deste trabalho, reflexões sobre questões conceituais e epistemológicas da Pesquisa social qualitativa a fim de afirmar seu valor científico e, b) o estudo das relações intergrupais e interpessoais, em que 'o afeto' passa a ser visto com uma dimensão muito maior, introduzido como uma questão política. Neste capítulo, daremos enfoque especial à compreensão do método utilizado para as análises de campo, baseado especialmente na triangulação de dados e na análise das categorias do cotidiano proposta por Maffesoli.

Nos Capítulo 3 e 4 ("Metodologia e Resultados e Discussão"), faz-se referência à história de formação dos grupos sociais dentro do assentamento, a maneira como se constitui hoje o assentamento da Fazenda Ipanema e seu contexto 
social, com destaque ao processo de organização que foi introduzido pela luta pela terra e o MST.

Descreveremos então o processo de formação do grupo de jovens JUMAFI para caracterização da dimensão do objeto de estudo, denominado de tempo 1 da pesquisa.

Apresentamos, ainda, no capítulo final (Conclusão) algumas reflexões sobre a questão da juventude rural e as alternativas e considerações metodológicas a respeito desta experiência de pesquisa. $\mathrm{O}$ intuito é fornecer elementos para a análise sobre as alternativas que contribuam para a organização de jovens, no enfrentamento de realidades semelhantes.

Nos anexos, poderemos encontrar documentos referentes ao planejamento de atividades do JUMAFI, na fase 1 do trabalho, mapa de localização da região onde se encontra o assentamento da Fazenda Ipanema e informações sobre o grupos jovens.

Ë importante salientar que, durante a elaboração deste trabalho, em muitos momentos, na parte teórica faço referência aos dados coletados em campo, na tentativa de estabelecer um diálogo entre as duas fases da dissertação. 


\section{REVISÃO DE LITERATURA}

Neste capítulo estaremos fazendo referência à literatura norteadora das análises para o desenvolvimento do trabalho.

\subsection{Adolescência e identidade: encontros entre vida cotidiana e privada}

A palavra identidade nos faz lembrar de identificação, idêntico, idade, único, diferente... mas, de fato, como a entendemos?

Quando discutimos o tema identidade, é importante definir a identidade que nos interessa, em que contexto está inserida, por que estamos perguntando a seu respeito, e com que propósitos a estaremos analisando. Torna-se necessário ter como referência situações concretas de vida, observando indivíduos e grupos em atividade social. (Branco ,1999, p.3).

Hobsbawn (1994, p.562), citado por Sawaia (1999, p.119), afirma que, "neste momento em que indivíduos, coletividades e territorialidades estão redefinindo-se reciprocamente, em ritmo acelerado, é inegável a contribuição da referência identitária que resgata a individualidade como valor cardeal (...) ela tem o sentido de permanência de um modo de ser para enfrentar esta crise e a ansiedade provocada pela desconstrução da razão, juntamente com a carência de utopias e a desordem global, que desenraizou o mundo através de um titânico processo econômico-técnico-científico do desenvolvimento capitalista". Sawaia (op. cit.) complementa que há um movimento de busca por esta identidade, ou seja, pela representação e construção do eu como sujeito único e igual a si mesmo, além do uso desta como referência de liberdade, felicidade e cidadania, nas relações interpessoais, intergrupais e internacionais.

Desta maneira, a identidade pode ser definida como um processo em constante construção, como um sistema aberto, que recebe informações e que se modifica, ao longo do tempo e do espaço. Trata-se, portanto, de um sistema vivo. 
Para Santos (1995, p.135), mesmo as identidades aparentemente mais sólidas, como as de homem, mulher, país africano, país latino-americano ou país europeu escondem negociações de sentido, jogos de polissemia, choques de temporalidade em constante processo de transformação, caracterizando-se como identificações em curso, em movimento e não como um conjunto de atributos permanentes.

Ianni (1996, p.24), citado por Sawaia (1999, p.119), salienta que as identidades locais são recriadas a partir de características como raça, religião, etnia, para se refugiar da globalização homogeneizadora.

Pode-se perceber, então, que estas recriações ou reconstruções identitárias buscam o re-conhecimento pela diferença, o "ser diferente", mesmo sendo igual, ou seja, pertencer a um mesmo conjunto com uma identidade específica, única, que o diferencie dos demais grupos.

Dependendo do contexto analisado, a identidade seria "uma categoria política disciplinadora das relações entre pessoas, grupos ou sociedade, usada para transformar o outro em estranho, igual, inimigo ou exótico" (Sawaia, 1999, p.123).

Estudos sobre (i)migrantes mostram que a identidade do lugar de origem favorece a criação de redes de solidariedade, facilita o acesso do "estrangeiro" aos bens e serviços, apesar da discriminação. Esta identidade transforma espaços de segregação em guetos de resistência e aconchego, lugares com 'calor' (Sawaia, 1997), antídoto ao desprezo da sociedade.

A partir deste ponto de vista, analisar a identidade de jovens assentados nos remete a um contexto sócio-político diferente. Trata-se de um grupo de pessoas de origens, raças e etnias distintas, vivendo um processo de reconstrução de suas identidades coletivas e individuais, e que trazem consigo sonhos e expectativas diferenciados, agora reunidos num mesmo tempo e lugar.

Este grupo recém-chegado a um novo lugar, em um novo contexto, ao vivenciar o processo de reconstrução identitária nos espaços cotidianos, seja na escola, seja no ambiente familiar ou profissional, ligado ao cultivo da terra e as atividades do MST, conquistou, ao longo do tempo, referências e papéis sociais dentro do processo de socialização vivido. Desta maneira, constituiu-se uma identidade, ainda que no estágio "adolescente", que "se manifesta em um momento 
'temporário' da vida e que se apresenta como identidade em 'movimento'", como afirma Branco (1999, p.03).

Torna-se evidente que este processo de consolidação de uma identidade deve ser analisado tendo em vista aspectos da realidade objetiva e subjetiva que compõem este cenário. Berger (1998, p.173) salienta que "a socialidade deve ser entendida e analisada em termos de um processo dialético em curso, composto de três momentos, p. exteriorização, objetivação e interiorização", e que, se analisados em relação a um fenômeno social, estes momentos não devem ser interpretados como ocorrendo em uma ordem temporal, podendo alguns deles inclusive ocorrer de maneira simultânea.

O mesmo autor coloca que "o indivíduo não nasce membro de uma sociedade, nasce com a predisposição para a sociabilidade e torna-se membro desta sociedade" (p.174). A este processo dialético entre os diferentes inputs que o cotidiano e as relações interpessoais e intergrupais vão tecendo ao longo de suas trajetórias, chama-se socialização.

É a partir destes pressupostos, que pretendemos analisar a realidade social dos atores principais deste estudo.

Os processos de sociabilidade que contribuem e geram as identidades em 'movimento', destes jovens tornam-se elementos fundamentais para a compreensão dos fenômenos sociais vistos em campo. Estes se encontram refletidos nos comportamentos, nas relações interpessoais, nas relações de grupo, e conseqüentemente, nas formas de organização vividas e pretendidas por estes jovens, bem como na sua relação com outros elementos que constituem esta enorme teia de relações sociais.

Santos (1995, p.81), em suas reflexões sobre espaço e cidadania, enfatiza o peso do "lugar", do território, e a partir daí a questão da cidadania. Ele salienta que "cada homem vale pelo lugar onde está. O seu valor como produtor, consumidor, cidadão depende de sua localização no território onde se está”. .

Assim, torna-se necessário ponderar sobre os aspectos expostos que serviram de "alicerce" orientador das práticas de intervenção e análise da construção participativa do trabalho de campo. 
Deste modo, dentro da temática da juventude rural, aliado à busca de alternativas que vinculem o jovem ao seu território, o objetivo é captar e perceber os momentos, fornecer os inputs necessários para facilitar o processo de apropriação das idéias/alternativas que compreendam os anseios e desejos dos jovens em sua relação com a terra, reconhecendo-se enquanto sujeito e autor de seus projetos. Nesse sentido, é importante para a compreensão das situações e das práticas educativas contribuir através de percepções/ferramentas (principalmente as já existentes no contexto onde se encontram) para possibilitar o processo de autorização, ou seja, o fato de se autorizar, que consiste no fato do ator social, numa atitude que pode ser traduzida com "a intenção e a capacidade conquistada de tornar-se a si mesmo seu próprio co-autor, de querer se situar explicitamente na origem de seus atos e, por conseguinte, dele mesmo enquanto sujeito"(Ardoino, 1999, p.28).

Buscando apoio nas reflexões de Santos (1995, p.331), quando mencionamos alternativas para o jovem assentado, refiro-me a alternativas que embora existentes, quando analisadas sob a ótica da ciência moderna, encontram-se muitas vezes suprimidas, silenciadas ou não-reconhecidas como verdades reais, ou seja, são alternativas que pouco têm a ver com as características e desejos explícitos destes atores. Acabando por provocar, ao invés de uma solução, uma devastação nos grupos, povos e nas práticas sociais.

Neste sentido Sen (2000, p.328) propõe a análise de alternativas enfatizando que, "não há uma única forma de conhecimento", e sim muitas, "tantas quantas práticas sociais que as geram e as sustentam (...) práticas sociais alternativas gerarão formas de conhecimento alternativas. Não reconhecê-las implica deslegitimar as práticas sociais que a sustentam e, nesse sentido, promover a exclusão social dos que as promovam".

Sobre estas considerações, acredito que haveria como decorrência..." $a$ preconização de atitudes que venham a revalorizar os conhecimentos e as práticas não-hegemônicas. E que esta atitude implica na escuta das práticas marginais desvelando-se rastros de utopias silenciadas, para fundamentar a busca de soluções aos problemas das sociedade contemporânea" (Tassara, 1997, p.43).

Complementando, usar a referência identitária para avaliar os problemas sociais significa, buscar orientações para recriar neste mundo inferiorizado, 
desenraizado pela tecnociência, novos espaços de representações democráticas, "recuperando o homem rico de necessidades com potencialidade de ação e emoção (...) significa buscar lugares onde a identidade deixa de ser destino e consciência 'em si', para se tornar consciência 'para si' e para o outro, sem perder o sentimento de ser único e, assim, poder dispor de si para si” (Sawaia, 1999, p.115).

\subsection{Exclusão e inserção social}

“Expandir as liberdades que temos razão para valorizar
não só torna nossa vida mais rica e mais desimpedida,
mas também permite que sejamos seres sociais mais completos,
pondo em prática nossas volições, interagindo com o mundo
em que vivemos e influenciando esse mundo”.

( Sen, 2000, p.29)

Os temas da exclusão e da inserção embora amplos e muitas vezes ambíguos, serão apresentados aqui, de maneira dialética, será traçado um paralelo entre o contexto e a determinação que denotam a exclusão social de um lado, e as formas propostas que buscam a sua transmutação em inclusão social, de outro.

O conceito exclusão social é bastante complexo, podendo ser também contraditório. Tem sido muito utilizado por diferentes áreas do conhecimento, possuindo interpretações diversas, que vão desde a desigualdade, como resultado de deficiência ou inadaptação social até a injustiça e exploração social.

Como coloca Sawaia (1999, p.7), "a ambigüidade inerente ao conceito de exclusão abre a possibilidade de suplantar os vícios do monolitismo analítico, que orientam as análises da desigualdade social. Grande parte dessas enfocam apenas uma de suas características em detrimento das demais, como as análises centradas no econômico, que abordam a exclusão como sinônimo de pobreza, e as centradas no social, que privilegiam o conceito de discriminação, minimizando o escopo analítico fundamental da exclusão, que é o da injustiça social”.

Para Castel (1995), analisado por Carreteiro (1999, p.85), a noção de exclusão social enfatiza apenas os aspectos negativos voltados para a não integração de um grupo ou do indivíduo em uma dada categoria, seja, ela econômica, institucional ou mesmo política. A noção dá autonomia às situações-limite sem estudar o processo de 
surgimento das mesmas. Propõe o conceito de desafiliação social ${ }^{4}$, que visa a analisar as diferentes situações ditas de 'exclusão', colocando em evidência seu caráter dinâmico e dialético. Completa dizendo que há sempre algum tipo de inserção ou de afiliação do sujeito individual ou coletivo, no interior de certas categorias e sistemas sociais. Como complementa Véras (1999, p.21), estão aqui consideradas as populações com insuficiência de recursos materiais e também aquelas fragilizadas pela instabilidade do tecido relacional, não somente em vias de pauperização mas de desafiliação, ou seja perda de vínculo societal..."o que chamei de desafiliação não é o equivalente necessariamente a perda total de vínculos, mas a ausência de inscrição do sujeito em estruturas que tem um sentido" (Castel, 1995, p.416) .

Atkinson (1998, p.119) citado por Verás (1999, p.34) determina este conceito como dinâmico, referindo-se tanto a processos quanto a situações conseqüentes “.... mais claramente que o conceito de pobreza, compreendido muito freqüentemente como referindo-se exclusivamente à renda, ele também estabelece a natureza multidimensional dos mecanismos através dos quais os indivíduos e grupos são excluídos das trocas sociais, das práticas componentes e dos direitos de integração social e de identidade. Indo muito além da preocupação da vida do trabalho”.

Deste modo, percebemos as diferentes qualidades e dimensões da exclusão, sendo em síntese, um processo complexo e multifacetado e, ao mesmo tempo sutil e dialético, pois só existe em relação a inclusão, como parte constitutiva dela, como coloca Sawaia (1999).

Partindo deste contexto, podemos inferir que o processo de exclusão social pode facilmente ser visto em uma comunidade em formação, como são os assentamentos rurais (Bergamasco, 1996; D’Incao, 1995; Branco, 1999). Dentro desta própria estrutura organizacional em construção (Berger,1998) encontramos diferentes grupos organizados ou não, como dos jovens ${ }^{5}$.

Esta dialética exclusão/inclusão pode ser melhor compreendida quando entendemos que a sociedade exclui para incluir e que esta transmutação é condição da ordem social desigual, o que implica o caráter 'ilusório' da inclusão.

\footnotetext{
${ }^{4}$ Desafiliação é um conceito criado por Castel (1995) in "As metamorfoses da questão social", onde significa a ruptura de vínculo social, "Efetivamente, desafiliado é aquele cuja trajetória é feita de uma série de rupturas com relação a estado de equilibrio anteriores, mais ou menos estáveis ou instáveis". ${ }^{5}$ Dados obtidos através de entrevistas no assentamento rural da Fazenda Ipanema incluindo jovens de 14 a 18 anos indicam que são aproximadamente 27 a 30\% desta população.
} 
Tudo isso faz pensar acerca dos projetos, das intervenções comunitárias, das tentativas externas de analisar o problema e das diferentes formas que são utilizadas para enfrentar esta realidade constatada e, conseqüentemente, gera reflexão a respeito dos tipos de oportunidades colocadas a estes grupos sociais.

A dinâmica entre estas oportunidades demonstra a capacidade de uma sociedade existir como sistema. É interessante lembrar que esta exclusão se faz pela ausência, que transporta parcela significativa da população para a condição dos sem $(\text { less })^{6}$, sem-terra, sem teto, sem-emprego e também pela quebra das rupturas societais como bem lembra Castel (1995). Esta condição, quando 'consertada' ou seja, no caso específico, quando os sem-terra conseguem a conquista da terra, um pedaço de chão, numa forma de inclusão, deve ser analisada, pois, o que se quer é tentar reintegra-se a sociedade, papel este feito pelo poder do Estado regulador e em grande parte pelo poder insistente da luta social na tentativa e na busca da emancipação social. Analisando-se sob este escopo, discute-se, que tipo de inclusão é esta?

Parafraseando Sawaia (1999, p.115) "O brado angustiante do 'eu quero ser gente' perpassa o subtexto de todos os discursos, ele não é apenas o desejo de igualar-se, mas de distinguir-se e ser reconhecido".

Martins (1997), classifica-os de "novos excluídos" ou de "exclusãointegrativa", ou ainda "inclusão perversa" (Sawaia,1999), atribuindo ao excluído o fato de estar em situação de carência material, mas sobretudo ser aquele que não é reconhecido como sujeito, que é estigmatizado, considerado nefasto ou perigoso a sociedade. O mesmo autor analisa a participação na esfera do consumo, que leva muitos indivíduos a se sentirem como 'incluídos' subjetivamente, embora estejam nas categorias de fato consideradas 'excluídas'.

No contexto sócio-político moderno, a teoria liberal capitalista como coloca Santos (1995, p.238), “começa por teorizar uma sociedade onde muitos - no início, a maioria - dos indivíduos livres e autônomos que prosseguem seus interesses na sociedade civil não são cidadãos, pela simples razão de que não podem participar politicamente na atividade do Estado (...) não podendo ser consideradas democráticas

\footnotetext{
${ }^{6}$ Termo em inglês utilizado para determinar a ausência de, 'sem'.
} 
senão depois de terem adotado o sufrágio universal, o que não acontece senão no novo século, na maioria dos casos, já com o século bem adentrado".

Sen (op. cit.) define como fundamentais as oportunidades reais oferecidas aos grupos sociais defendendo duas razões pelas quais a liberdade seria central para o processo de desenvolvimento: (1) a razão avaliatória referindo-se ao aumento da liberdade das pessoas e (2) a razão da eficácia que seria aquela em que a realização do desenvolvimento depende inteiramente da livre condição de agente ${ }^{7}$ das pessoas.

Branco (1999, p.63) em seu estudo sobre a identidade de jovens assentados, referindo-se a conquista da terra no assentamento rural afirma que,"o território conquistado se legalizou, e com isso, colocou os novos camponeses a mercê de uma lógica que isola e depois exclui os que não se tornam competitivos".

Abramovay (1998, p.40) levanta a questão da capacidade do jovem assentado de pensar estrategicamente sobre o seu futuro no campo. Nesse sentido, fica evidente a necessidade de diferenciar as situações nas quais a agricultura e o meio rural para os jovens são uma escolha preferencial daquelas que resultam, na verdade da impossibilidade de realizar um projeto pessoal, ou seja em virtude do peso das relações patriarcais.

Estas distorções deveriam ser analisadas e corrigidas em nome da cidadania, do desenvolvimento e do encontro/construção de um novo paradigma metodológico na ciência interdisciplinar, analisando a realidade como ela se apresenta, sem recortes drásticos e pontuais que possam estar podando-a de ser vista de maneira complexa, denotando erro nas análises em separado. As análises complexas poderiam nos orientar para o estabelecimento de reflexões sobre os distintos elementos que fazem parte do real. Como apresenta Morin (1988 e 1996) ${ }^{8}$, citado por Cascino (1998, p.18) o pensamento complexo pretende voltar-se a reelaboração das formulações e das leituras do real“...buscando ressaltar a intervenção permanente que tais cruzamentos produzem (...) remeter-se pois ao permanente estranhamento das coisas e de si próprio é o sentido da busca da complexidade".

\footnotetext{
${ }^{7}$ Condição de agente é o termo utilizado pelo autor para representar a condição necessária com que as pessoas possam ter liberdade de tipos diferentes para que possam atuar livre e sustentavelmente. "A livre condição do agente não é só em si, uma parte constitutiva do desenvolvimento, mas também contribui para fortalecer outros tipos de condições de agentes livres" (p.19)

${ }_{8}$ Pensamento apresentado por Morin, entre outros autores, sobre a teoria da Complexidade. Desvelando uma nova forma de interpretar os fenômenos naturais sociais.
} 
Cascino (1998, p.19) complementa dizendo que, "relacionar os fenômenos e seus desdobramentos, principalmente sobre as formas de ler o cotidiano, considerando os eventos sociais e culturais, acontecimentos que se dão a nível das sociedades humanas, quer no coletivo como no individual, na esfera da subjetividade como da objetividade impõe instrumentos de ordem teóricos de análise completamente diferentes daqueles elaborados pelas ciências clássicas".

Deste modo acredito que, enquanto educadores ambientais, através das experiências, das percepções, das contribuições recebidas nesta caminhada, do estabelecimento de referenciais teóricos elaborados e em elaboração, na busca da formação e re-formação dos valores e formas de educação e da relação com os demais seres, além da revisão do papel humano e espiritual do educador, estamos caminhando rumo ao encontro de nossas utopias, na busca de um caminho mais simples, natural, da maneira que se nos apresenta, retirando os 'ante-olhos' convencionais, fugindo dos estereótipos viciados da pesquisa e deixando fluir a intuição e o afeto na tentativa de buscar compreender o ser humano, o sujeito e suas inter-relações.

Como relembra Maffesoli (1996) "o indivíduo não é mais uma entidade estável provida de identidade intangível capaz de fazer sua própria história, antes de se associar com outros indivíduos autônomos para fazer a história do mundo. Movido por uma pulsão gregoria, é também o protagonista de uma ambiência afetual”.

\subsection{Educação Ambiental...uma utopia realista.}

"O moinho de vento coopera e "deixa ser" ao vento, e assim ajuda a revelar o que o vento é".

(Heidegger)

Discorrer sobre o tema Educação, já é em si, uma tarefa deveras complexa, quando a ela acrescenta-se o adjetivo ambiental, esta se torna ainda maior. Porém facilitando a compreensão, unem-se palavras que na prática não poderiam estar separadas, uma vez que seria difícil imaginar uma educação não-ambiental. Por outro lado, o termo E.A. tem dado margem a diferentes conceitos e definições, pois, se trata muitas vezes, da tentativa de unir educação somada ao ambiente, num ramo do conhecimento separado, por fim. 
A Educação Ambiental que defendemos busca raízes na compreensão dos valores e hábitos humanos em relação ao ambiente. Trata-se de uma educação menos dissociada, entendendo o homem e a natureza como partes de um mesmo todo, discutindo a ação-educativa, a educação enquanto ambiente $^{9}$, de maneira interdisciplinar, norteado por uma pedagogia de autonomia.

Assumindo integralmente seu caráter de complexidade, concordamos com Barbosa (1998, p.8) quando afirma "Todos aqueles que atuam no campo da educação, seja lecionando, administrando, orientando, supervisionando, coordenando, terão de se apresentar formados para realizarem o ato educativo em toda sua complexidade em qualquer situação (...) o papel do educador, nesse caso, será sempre ampliar ao máximo o aproveitamento das oportunidades múltiplas e de intensidades infindáveis para que os sujeitos se tornem autores-cidadãos cada vez mais".

Ortega y Gasset, citado por Brandão (1981, p.82-83), complementam dizendo que "se a educação é transformação de uma realidade, de acordo com uma idéia melhor que possuímos, e se a educação só pode ser de caráter social, resultará que a pedagogia é a ciência de transformar a sociedade".

É importante ressaltar o aspecto 'mutante' da educação, ou seja, ela não deve ser pensada como uma realidade supra-humana, sagrada e, portanto, imutável. Brandão (1981, p.22) salienta que “...ao contrário do que acontece com os deuses, para se crer na educação é preciso primeiro dessacralizá-la (...) é a idéia de que a educação é uma invenção humana e, se em algum lugar foi feita de algum modo, pode ser mais adiante feita de outro, diferente diverso, até oposto. É preciso acreditar que, antes determinados tipos de homens criam determinados tipos de educação, para que, depois, ela recrie determinados tipos de homens".

Nesta construção diferenciada de educação, busquei integrar partes até então separadas, dissociadas, divididas por separações hierárquicas que se reproduziram ao passar dos anos.

\footnotetext{
${ }^{9}$ Ambiente: refere-se ao ambiente real em que vivemos, a todos os elementos externos e internos que o compõe, na existência de todos os seres naturais, que incluem todos os tipos de sistemas, com os sociais - família ou comunidade - e também ecossistemas complexos, contendo organismos menores que têm considerável autonomia e estão integrados harmoniosamente no todo". (Capra, 1993, p.4445) citado por Grun (1996, p. 64).
} 
Cabe-nos a tarefa de resgatar a história desta separação/fragmentação, na tentativa de juntar as partes separadas integrando-as com o real. É nessa tarefa que nos deparamos com dificuldades e estranhezas de partes que, embora irmãs foram abruptamente separadas, de maneira que fazem sentido para a maioria das pessoas, tornando-se parte da lógica comum. O contrário torna-se mais difícil de fazer.

Neste sentido, quando discutimos $\mathrm{EA}^{10}$, inevitavelmente, mencionamos o termo interdisciplinariedade. Ele pode ser entendido não apenas como fruto de junções ou agrupa-mentos entre-disciplinas, mas como, uma forma de pensar e agir/analisar as inter-ações entre os diferentes conceitos, olhares e compreensões acerca dos fenômenos naturais sociais que compõe a tarefa de educar.

Trata-se, desta maneira, de buscar uma compreensão holística ${ }^{11}$, menos fragmentada, das situações apresentadas pelos trabalhos de pesquisa social, que desenvolvemos, procurando ler as entrelinhas daquilo que observamos como verdades abstratas nas práticas de campo a fim de incorporar este conhecimento enquanto verdade científica, tornando-nos menos 'cegos' perante a realidade, analisando o sistema sócio-político institucional em que estamos imersos e o paradigma da modernidade que de uma maneira geral impera, sugere e orienta atitudes voltadas aos trabalhos sociais.

Buscando um eixo reflexivo para a nossa conversa sobre o surgimento das preocupações ambientais e, conseqüentemente, da Educação Ambiental, reconhecemos uma relação direta existente entre os passos históricos da humanidade e a questão ambiental, do Homo sapiens e da sua versão demens que pode ser melhor visualizada nas palavras de Morin (1997, p.11), quando se refere à natureza ambígua do homem..."atribuindo-lhe a qualidade de sapiens, ou seja, ser racional e sábio, que sem dúvida é uma idéia pouco racional e sábia, e ser Homo que implicaria em ser igualmente demens, isto é, em manifestar uma afetividade extrema, convulsiva, com paixões, cóleras, gritos, mudanças brutais de humor; em carregar consigo uma fonte permanente de delírio, em crer na virtude de sacrificios sanguinolentos e apresentar uma tendência a desmesura" (Unger,1991, p. 40).

\footnotetext{
${ }^{11}$ Holística, p. refere-se a uma visão que busca contemplar os possíveis aspectos quando se analisa uma situação. Trata-se de um olhar amplo e completo. Holos do grego significa todo. Segundo Viezzer \& Ovalles (1994, p.20) seria "a emergência de uma percepção renovada de mundo, uma forma integra de ler a realidade e atuar sobre ela".
} 
Considera-se que há no ser humano uma fonte permanente de Hybris, palavra grega designada para o desejo voraz e excessivo.

Morin (1998, p.9) nos diz que "a loucura humana é fonte de ódio, crueldade, barbárie, cegueira, mas que sem as desordens da afetividade e as irrupções do imaginário, e sem a loucura do impossível, não haveria élan, criação, invenção, amor, poesia”.

Esta necessidade descontrolada de obter, possuir, dominar, a hybris, que na sociedade grega era reconhecida e repensada como algo a ser mantido sob controle, encontra eco nos nossas dias e, sua manifestação mais explicita pode ser vista na destruição ambiental e cultural, na tendência de homogeneização global, que representa como menciona Unger (1991, p.32) "o projeto de dominação e controle de tudo que existe, a ruptura da dimensão cosmo-polita do homem, a busca de mais e mais poder sobre a natureza, sobre tudo e todos, o antropocentrismo, formando o eixo que, enquanto civilização, gravitamos".

Heidegger citado por Unger (1991), expõe a "auto-idolatria do homem moderno, que se erige em fonte de todo o valor e medida da realidade e da verdade. Esta idolatria humana nos leva a transgredir os nossos limites, e a desrespeitar os limites dos outros seres".

Neste sentido, podemos visualizar esta 'desmesura' exercida por parte da sociedade de consumo capitalista levando ao surgimento relativamente recente de movimentos sociais de resistência como o ambientalista, o dos trabalhadores semterra, os sem-teto, entre outros, que surgem como reflexo desta transgressão de limites e desrespeito a outros seres e conseqüentemente a própria vida. De uma maneira geral é uma resposta dos 'less' dos 'sem' que se encontram do outro lado da balança da desmesura.

Nas palavras de Castells (1999, p.94)"segundo uma antiga lei da evolução social, a resistência enfrenta a dominação, a delegação de poderes reage contra a falta de poderes, projetos alternativos contestam a lógica inerente a nova ordem global, cada vez mais percebida pelas pessoas de todo o planeta como se fosse desordem".

Nesta perspectiva, ao longo de nossa história, a preocupação ambiental já existia muito antes, mas é apenas nestas últimas três décadas que se torna evidente e 
necessária para a sobrevivência dos sistemas político-institucionais existentes, seja de esquerda ou de direita, começando a fazer parte das agendas de prioridades.

Cronologicamente, Worster (1992) citado por Grun (1996, p.16) que denomina o ano de 1945 como o 'início da idade ecológica', quando o mundo sofre com os experimentos da Bomba $\mathrm{H}$, atentado que mudaria os rumos da história ambiental.

Diegues (1996, p.40) sintetiza dizendo que "o ecologismo foi inspirado pelos escritos de Henry Thoreau, pelo poeta Gray Snider - 'o poeta verde' - para quem as árvores e as águas eram classes tão exploradas como o proletariado. E ainda, por Barry Commoner (1971) citado pelo mesmo autor, que responsabilizava a tecnologia moderna pela crise ambiental".

Ainda de acordo com Diegues (1996), em 1962, Rachel Carson faz a denúncia sobre o uso dos biocidas na agricultura e mostra o desaparecimento de espécies através da publicação do livro 'A primavera silenciosa' que, dotado de grande sensibilidade, atinge o grande público, tornando-se um clássico do ambientalismo contemporâneo. Em 1968, Erlich publica o The population bomb chamando a atenção para o crescimento exponencial da população mundial e para a inviabilidade da civilização moderna a médio prazo.

Percorrendo este caminho, como analisa Diegues (op. cit.) o ambientalismo também recebe grande influência da "contra-cultura", vigorosa nos anos 60, e que constitui uma das inspirações do movimento hippie. Herdeiro dos movimentos libertários, o ambientalismo questiona uma série de valores da sociedade capitalista "a proteção da natureza, o não-consumo, a autonomia, o pacifismo eram apenas algumas de muitas bandeiras levantadas por aqueles que começavam a ser chamados 'ecologistas' (Diegues, 1996)".

Dupuy (1980) chamou a década de 70 de 'nebulosa ecológica', em que surgiram diferentes movimentos que, na sua opinião, não poderiam ser chamados de movimentos ambientalistas, mas começavam a se tornar presentes e a 'irritar' como coloca Grun, tanto a direta quanto a esquerda conservadora.

Com a crise do petróleo em 1973, há uma corrida rumo a energia nuclear, "com isso, aquilo que eram anseios indefinidos e efêmeros começa a tomar forma de um movimento social organizado, o movimento ecológico” (Grun 1996, p.17). 
A partir daí uma série de eventos marcaram a trilha que colocava a problemática ambiental a nível planetário, destacando-se o Relatório do Clube de Roma $^{12}$ e a I Conferência Mundial de Meio Ambiente Humano, em Estocolmo, Suécia, em 1972. A partir desta conferência a Educação Ambiental passa a ser referência constante nos discursos oficiais relativos à necessidade de transformação da postura dos indivíduos frente ao ambiente (Sorrentino, 1998; Dias, 1995; Junqueira ,1998, Grun, 1996).

Em 1977, a Conferência Intergovernamental sobre Educação Ambiental, acontece em Tbilissi, Geórgia (ex-URSS) constituindo-se em um marco do Programa Internacional de EA, considerado o I Congresso Mundial de Educação Ambiental.

Segundo a Unesco (1980, p.107) a Educação Ambiental deveria "propiciar a tomada de consciência generalizada a respeito das causas e conseqüências que tem para o homem, para a sociedade e para a comunidade internacional os problemas de meio-ambiente e estimular, na vida diária, profissional e na ação para o desenvolvimento, uma ética, atitudes e condutas individuais e coletivas que contribuam para a proteção e o melhoramento do meio ambiente".

Em Moscou, no ano de 1987 ressaltando as afirmações de Tbilissi, ocorre o Congresso Internacional sobre Educação e Formação Relativas ao meio ambiente, considerado o II Congresso mundial sobre Educação Ambiental.

O marco forte desta discussão em torno da degradação desenfreada, ocorrido nestes últimos anos, foi a Conferência das Nações Unidas sobre Meio Ambiente e Desenvolvimento Humano, a ECO 92, que aconteceu no Rio de Janeiro, evento que mobilizou cerca de 170 países, tornando-se um grande avanço na maneira de compreender os graves problemas ambientais, momento de reflexão e definições de estratégias para o século XXI, neste contexto atual "caracterizado pela superação de crises econômicas, sociais, politicas, culturais e ambientais que transcendem as fronteiras nacionais e os espaços locais” (Junqueira, 1998, p.82).

\footnotetext{
${ }^{12}$ O Clube de Roma grupo constituído quase que exclusivamente por empresários preocupados com as conseqüências desastrosas que a crise ecológica poderia trazer.
} 
Desta maneira, a E.A. poderia ser considerada como a melhor porta de entrada para um pensamento tão amplo, uma vez que questiona os valores, os modelos vigentes e propõe relacionamentos mais harmônicos entre todos os seres vivos do planeta. (Pádua, 1997).

Cascino (1998, p.22) complementa dizendo que, "esta nova educação só se constitui no cruzamento de conceitos simples mas vitais à qualidade e ao equilíbrio da vida na terra, p. cooperação, pluralismo, paz, ética, criatividade, afetividade, resistência, solidariedade, dignidade, coletividade, participação, igualdade, espiritualidade e amor".

O mesmo autor complementa que, passamos então por uma revisão de conceitos e atitudes buscando uma nova concepção de ecologia e criando uma nova estrutura de sociedade humana fundamentada numa ética ambiental ecocêntrica e em uma percepção sistêmica da vida.

Para que isso aconteça, analisando as condições atuais em que nos encontramos, situação de crise social, política, moral e relembrando que a etimologia da palavra crise vem do grego Krineim, momento de discernimento "a decisão de repensar a maneira pela qual tecemos nossa inserção no mundo é também a decisão de nos libertarmos do automatismo de nossos hábitos" (Unger, 1991, p.36).

Sorrentino (1998, p.29) traz uma contribuição para esta discussão, fazendo uma leitura dos objetivos de distintos projetos de Educação Ambiental, em diversos locais no país, identificando quatro grandes conjuntos de temas em educação ambiental: biológicos, espirituais/culturais, políticos e econômicos.

Segundo ele, "Esses quatro conjuntos de temas, podem ser reduzidos a um grande objetivo geral, que talvez expresse uma tendência de convergência ente os diversos fazeres educativos voltados a questão ambiental: Contribuir para a conservação da biodiversidade, para a auto realização individual e comunitária e para a autogestão política econômica, através de processos educativos/participativos que promovam a melhoria do meio ambiente e da qualidade de vida".

Rumo a esta nova educação, baseada em uma visão ecológica diferenciada, perseguimos esta utopia ecológica que como menciona Santos (1995, p.40-43) 
"No final do século a única utopia realista é a ecológica e democrática. É realista porque assenta num princípio de realidade que é crescentemente partilhado (...) esse princípio de realidade consiste na contradição crescente entre o ecossistema do planeta terra, que é finito, e a acumulação de capital, que é tendencialmente infinita. Por outro lado, a utopia ecológica é utópica, porque a sua realização pressupõe a transformação global, não só dos modos de produção, mas também do conhecimento científico, dos quadros de vida, das formas de sociabilidade e dos universos simbólicos e pressupõe, acima de tudo, uma nova relação paradigmática com a natureza, que substitua a relação paradigmática moderna. É uma utopia democrática porque a transformação a que aspira pressupõe a repolitização da realidade e o exercício radical da cidadania individual e coletiva, incluindo nela a carta dos direitos humanos da natureza. É uma utopia caótica porque não tem sujeito histórico privilegiado. Os seus protagonistas são todos os que, nas diferentes constelações de poder que constituem as práticas sociais, exercem sobre eles do que pelo poder que exercem sobre outrem. Foi a partir da consciência da opressão que nas últimas três décadas se formaram os novos movimentos sociais".

Portanto, é imprescindível que se pense na construção de uma ética para a convivência sadia no planeta terra. Como se refere Unger (1991, p.71), dos movimentos emergentes, o ecológico é um dos mais abrangentes, porque "é portador de valores e interesses que ultrapassam as fronteiras de classe, sexo, raça e nação (...) Para aqueles que pensam a questão ecológica em seus aspectos filosóficos e espirituais (...) para estes pensadores tal ética somente poderá surgir a partir da superação da visão de mundo que tentou reduzir todos os seres à condição de objetos cujo valor reside no lucro que podem produzir".

Esta noção/percepção que surge com força significativa nas diferentes áreas do conhecimento, em diferentes partes do globo, em diferentes grupos, etnias e culturas, parece estar respondendo a uma ordem subjetiva dentro da aparente desordem do universo.

Esta abordagem diferenciada da discussão ecológica, mais aprofundada, enraizada na discussão do "ser", na verdade surgiu há algum tempo com o nome de 
Ecologia profunda (Deep ecology) ${ }^{13}$. Naess (1982), citado por Unger (op. cit.), afirma que "a essência da ecologia profunda é fazer indagações. O adjetivo profundo realça o fato de que perguntamos o porque e como, quando outros não o fazem (...) por exemplo a ecologia não pergunta que tipo de sociedade seria a mais adequada para manter o ecossistema específico... perguntamos se a presente sociedade preenche as necessidades humanas básicas como amor e segurança e acesso à natureza, e ao fazer. Questionamos os pressupostos básicos de nossa sociedade...não nos limitamos a uma abordagem científica; temos a obrigação de verbalizar uma visão abrangente”.

Outros autores, como Heiddeger e Zimmerman citados por Unger (1991) expõem reflexões filosóficas acerca do comportamento humano e o desrespeito aos limites, denunciando uma 'revolta contra a natureza' e reforçando a necessidade de repensar de maneira mais profunda a ecologia, numa critica ao humanismo antropocêntrico e secular. Centralizam a discussão na idéia de que o homem moderno vai desenvolvendo em torno dele mesmo uma certa supremacia existencial:

"o caminho estaria aberto para uma compreensão na qual, em termos ontológicos, "ser" é para o homem moderno ser representável para o sujeito racional. Heidegger dirá que é esta compreensão do ser como objetividade que possibilitará que a racionalidade tecnológica seja usada para oprimir a natureza e os outros homens".

"Perdemos todo o sentido do transcendente, assumimos que o sentimento de valor, realidade e verdade, somos nós mesmos (...) esquecendo nossa essencial finitude e dependência, conseqüentemente assumimos que éramos nós mesmos nossa única fonte e o único fundamento...e justificamos nosso assalto à natureza, dizendo que só os seres humanos têm real importância, e que os objetos naturais têm apenas o valor que nós lhe atribuímos" (Zimmermann citado por Unger, 1991).

Torna-se importante mencionar que faço este percurso para mostrar as diferentes formas pelas quais a educação ambiental emana e se faz presente, segundo uma nossa maneira bastante peculiar de compreendê-la. Acredito que é a partir desta maneira diferente de perceber a natureza, o homem e a relação entre eles, que transformaremos o ser humano, não mais num tirano da natureza, mas em “um canal

\footnotetext{
${ }^{13}$ Termo criado em 1973 por Arne Naess, professor de filosofia e ecologia norueguês.
} 
através do qual o cosmos pode se presentificar de novas maneiras, uma abertura para o ser-vir" (Unger, op.cit., p.90).

Castells (1999, p.158) diz que"para nos integrarmos ao nosso eu cosmológico precisamos primeiramente transformar nossa própria noção de tempo, sentir o 'tempo glacial'14 passando por nossas vidas, a energia das estrelas fluindo em nossas veias, perceber os rios de nossos pensamentos desembocando em um fluxo contínuo nos oceanos ilimitados da matéria viva multiforme”.

Reforçando o fio condutor destas idéias, temos apoio, ainda, nas palavras de Castells (1999), segundo as quais, que "a noção holística de integração entre seres humanos e natureza, conforme sustentada pelos defensores da 'ecologia profunda', não está se referindo a uma ingênua veneração de paisagens naturais intocadas, mas sim ao princípio de que a unidade de experiência mais relevante não é o individuo ou, ainda nesse sentido, comunidades de seres humanos consideradas a partir de uma perspectiva histórica”.

Dentro deste contexto, através deste longo exercício teórico percorrido por diferentes áreas do conhecimento, fui tecendo uma rede, bricolando, a fim de trazer a tona os elementos que julguei necessário para compreender o problema estudado em campo.

Tratou-se de explicitar o pensamento sobre EA, e relacioná-lo ao cotidiano de pesquisa vivido no assentamento rural.

$\mathrm{O}$ assentamento rural, neste caso, traz uma grande riqueza nos fenômenos sociais observados. Quando trabalhamos especificamente com jovens remetemos-nos à seguinte reflexão: existem necessidades prioritárias básicas determinadas por eles como saúde, lazer, educação, a necessidade de reconhecimento e aceitação pela sociedade e pela própria comunidade. A questão ambiental no olhar destes jovens é percebida como essencial e prioritária, embora não diretamente mencionada, sendo necessário valorizar esta percepção, demonstrando o quanto a questão ambiental está imbricada dentro das necessidades básicas e reais de sua comunidade e de sua vida social.

\footnotetext{
14 "Em termos objetivos e pessoais viver no 'tempo glacial' significa estabelecer os parâmetros das nossas vidas a partir da vida de nossos filhos, e dos filhos dos nossos filhos. Portanto, o modo de administrarmos nossas vidas e instituições em função deles, tanto quanto em nossa própria causa." Castells (1999, p.159).
} 
Neste caso, observamos que a EA deve estar necessariamente vinculada a um trabalho contínuo, funcionando como ponte de ligação capaz de fazer despertar estas percepções. Nota-se que esta percepção ambiental diferenciada, que pode ser vista como um canal, é algumas vezes percebida em ações cotidianas dos jovens e das pessoas da comunidade, porém outras vezes é encarada por eles como um aspecto negativo, como um 'atraso', uma vez que, o progresso seria aquele ligado a moradia na cidade, ao aumento do consumo doméstico, ao conforto material excessivo.

Por outro lado, esta percepção cotidiana das ações nos faz refletir sobre a necessidade de resgate de muitas práticas e atitudes coletivas e individuais, que refletem preocupações ambientais e, também, sobre as oportunidades adequadas que fariam brotar estas atitudes com maior ênfase e valor.

Estas reflexões nos trazem elementos importantes para se pensar as práticas e as reflexões teóricas sobre o tema Educação Ambiental, assim como o processo de avaliação no tema.

Como exemplo, podemos citar Grun (1996), ao analisar o papel da Educação Ambiental no Brasil, salienta que $o$ "discurso de EA no Brasil tem características preocupantes e perigosas (...) ele é um discurso altamente normativo de uma cultura branca e "limpinha" que quer se impor a outras práticas culturais" e indo mais adiante complementa dizendo, "se quer há um consenso mínimo entre o Educadores ambientais sobre o que é EA".

Vale lembrar que, tratando se um conhecimento em construção, muito tem se produzido nos últimos anos no Brasil sob a égide da Educação Ambiental, e conseqüentemente, uma riqueza enorme de iniciativas pode ser visualizada em diferentes trabalhos. Compreender e contribuir para esta construção é sem dúvida, um desafio do presente e do futuro. Afinal, trata-se da construção de um conhecimento novo.

Neste sentido, a preocupação em constituir uma base reflexiva, um marco lógico, para a compreensão da abrangência da Educação Ambiental se torna bastante significativa e necessária para definirmos as idéias norteadoras deste trabalho. 


\subsubsection{A arqueologia virtual presente: um olhar diferenciado sobre a realidade}

A arqueologia virtual presente é um conceito proposto por Santos (1995) que tentarei aqui expor de maneira resumida para contribuir na compreensão dos anseios utópicos ao qual nos referíamos acima, além de demarcar a direção à qual busquei desenvolver estas estratégias de trabalho e atuação.

É uma arqueologia virtual porque só interessa escavar sobre o que não foi feito e porque não foi feito, aprofundando, investigando, porque algumas opções deixaram de ser enquanto alternativas.

Refiro-me, portanto, a análise feita neste trabalho, sobre a valorização do cotidiano enquanto lugar que emana a verdade social, nos pequenos detalhes e atitudes muitas vezes despercebidos e, por conseguinte, ignorados.

Nesse sentido, como coloca o autor, "a escavação é orientada para os silêncios e para os silenciamentos, para as tradições suprimidas, para as experiências subalternas, para a perspectiva das vitimas, para os oprimidos, para as margens, para a periferia, para as fronteiras, para o sul do norte, para a fome da fartura, para a miséria da opulência, para a tradição do que não foi deixado existir, para os começos antes de serem fim, para a inteligibilidade que nunca foi compreendida, para as línguas e estilos de vida proibidos, para o lixo intratável do bem-estar mercantil, para o suor inscrito no pronto a vestir lavado, para a natureza nas toneladas de $\mathrm{CO}_{2}$ imponderavelmente leves nos nossos ombros" (p.324-5).

Santos (op. cit.) defende, "tudo isto com um único objetivo de descompor a cama onde as subjetividades dormem um sono injusto (...) o que se pretende é pois, uma concorrência epistemológica leal entre conhecimentos como processo de reinventar as alternativas de prática social de que carecemos ou que afinal apenas ignoramos ou não ousamos desejar” (p.329).

Serres (1993, p.47-8), autor que introduz o pensamento mestiço, traduzido na filosofia mestiça, faz um paralelo entre o sistema solar para explicar os silêncios e 'silenciamentos' humanos:

"nem o sol, nem a terra situam-se no centro do mundo(...) Kepler descobriu que o movimento geral dos astros segue órbitas elípticas, que se referem, é certo, quando em conjunto, ao doador solar de força e luz. Mas cada uma, além disso, tem um 
segundo foco do qual não se fala nunca, tão eficaz e necessário quanto o primeiro, uma espécie de segundo sol negro. Ao sol podem ser reunidos uma espécie de zona de forma anelar, exposta, quer dizer, colocada a margem do sol. Os fracos e os simples, pobres ou analfabetos, toda a suave multidão tão menosprezada pelos doutos, que não vêem senão como objeto de seus estudos, os excluídos do saber canônico se orientam com freqüência por esses pontos negros, sem dúvida porque eles não os cegam nem os sufocam, ou porque os sustentam”.

Complementa seu pensamento dizendo que, de fato, o centro real de cada órbita se localiza exatamente entre esses dois grandes focos, em um lugar mestiço:

“Escorregadio o lugar mestiço expõe o passante. Mas nada se passa sem este escorregão. Ninguém jamais se modificou, nem coisa alguma no mundo, sem se recuperar de uma queda. Toda evolução e todo o aprendizado exigem a passagem pelo lugar mestiço".

Trabalhar o silêncio dos silenciados, buscar espaço e trazer a tona, analisar então silenciamentos por tanto tempo sufocados, esquecidos, empoeirados, mas que, resistem, é o caminho que tem trilhado, algumas vezes, muitos trabalhos desenvolvidos sob a ótica da Educação Ambiental.

Para Tassara (1997, p.43) interpretando Santos, estaria acontecendo "a emergência de uma motivação eco-socialista, e que poderia ser vista como um dos motores da Educação Ambiental e dos ambientalistas, projetos utópicos, disparados por desejos de transformação mobilizados por energias utópicas".

Aliamos, portanto, esta busca a uma busca utópica, considerando que a utopia é duplamente reativa, que por um lado é uma chamada de atenção para o que não existe como parte integrante, silenciada. Por outro lado, a utopia é desigualmente utópica, como menciona Santos (op. cit.) "na medida em que a imaginação do novo é composta em parte por novas combinações e novas escalas do que existe".

Encontramos bastante coerência entre esta teoria e o que pretendemos fazer em campo, nas pesquisas sociais em EA. Trata-se de buscar o que não deu certo, porque não foi feito; e re-treinar a observação para pontos antes desconhecidos, buscando uma heterotopia, ou seja, “...o objetivo desta deslocação é tornar possível uma visão telescópica do centro e, do mesmo passo, uma visão microscópica do que 
ele exclui para ser centro" (Serres, 1993, p.15). Essa trilha nos leva por caminhos, pouquíssimas vezes percorridos.

A arqueologia virtual presente propõe este enfoque, que sugere novas práticas sociais, que podem levar, através desta heterotopia, a compreender, e até mesmo a repensar, o significado de resultados ou do conceito de sucesso ao qual nos referimos na academia.

Com isso, pretende-se resgatar novas formas de conhecimento, constituindose alternativas para grupos marginais, que de fato tenham coerência com sua realidade, tentando enxergar os "sóis negros" já existentes, que os guiam, e que o nosso olhar não se habituou a ver.

\subsection{Participação e organização social}

"A liberdade de mover-nos, arriscar-nos vem sendo submetida a uma certa padronização de fórmulas, de maneiras de ser em relação às quais somos avaliados (...) não mais pelo Estado autoritário, mas pelo poder invisivel da domesticação alienante". (Freire, 2000, p.128)

Ultimamente, o termo participação tem sido muito valorizado. Utilizado como marketing para campanhas publicitárias, slogan políticos e muitas vezes, mencionado como garantia de processos democráticos em diferentes esferas da sociedade, nos remete a necessidade de revisão e compreensão de seu conceito.

A noção de participação está relacionada a um processo, no qual, o indivíduo se reconheça como parte integrante de determinado grupo social e que sinta motivado a fazer parte.

Em muitos trabalhos de Educação Ambiental, sempre enfatiza-se a questão da participação atrelada à de sensibilização. Considera-se esta última como elemento focal para a ação educativa.

No entanto, ao mesmo tempo em que a participação é vista como o grande caminho para a resolução de problemas, gera em torno de si uma grande polêmica, tornando-se um dos grandes dilemas a serem enfrentados em trabalhos educativos. 
Demo (2001, p.171) salienta que a condição de pobreza política ${ }^{15}$ ofusca a liberdade de expressão e, conseqüentemente, de participação dos pobres. Nesse sentido, o autor reforça dizendo que "exata população vive em estado de ignorância, no sentido da falta mínima da consciência crítica de seus direitos (..) sem condições mínimas de se fazer sujeito de sua história. Não se coíbe apenas que sobreviva, coíbe-se sobretudo que se emancipe(..) Todavia o traço mais central é a capacidade de consciência crítica e de organização política para atingir a necessária competência política”, frente às oportunidades que apareçam.

Neste contexto alguns aspectos são fundamentais para a compreensão das formas de participação que se estimula em determinado grupo social, levando em consideração o contexto em que se está inserido, o aspecto temporal na comunidade e as diferentes formas que esta pode emergir, expressas em manifestações diversas.

É certo que no Brasil, temos uma história bastante marcada por sucessivos regimes ditatoriais, que durante anos reprimiu as populações, favorecendo o que é chamado por La Boétie (1999) de 'servidão voluntária' e que ainda hoje impera sob a forma de forças aparentemente invisíveis aos olhos menos preparados. De acordo com Freire (2000, p.128) "Há um sinal dos tempos que me assusta(...)é claro que já não se trata de asfixia truculentamente realizada pelo rei despótico sobre seus súditos, pelo senhor feudal sobre seus vassalos, pelo colonizador sobre os colonizados, pelo dono da fábrica sobre seus operários, pelo Estado autoritário pelos cidadãos, mas pelo poder invisível da domesticação alienante que alcança a eficiência extraordinária no que venho chamando de 'burocratização da mente,".

Demo (2001, p.176) coloca ainda que "é fundamental reconhecer que a participação pode ser usada como fetiche ou slogan para um quadro histórico que não apresenta o mínimo de competência política" e complementa dizendo que "tão importante quanto saber referenciar-se à participação popular, é saber dizer até que ponto ela existe ou é fantasia"

O mesmo autor complementa dizendo que, não se pode supor que as populações possam participar devidamente, sem antes conquistar seu processo de autonomia, lembrando que, "Se isso não ocorrer é sempre possivel fazer as

\footnotetext{
${ }^{15} \mathrm{O}$ autor define pobreza política como a condição do pobre sequer saber que é coibido de saber que é pobre. Vive em estado de ignorância, no sentido da falta de mínima consciência crítica de seus direitos.
} 
comunidades dizerem o que jamais disseram ou nem sequer saberiam dizer, manipular líderes para que façam a comunidade dizer o que os interesses econômicos pretendem, inventar novos líderes à revelia das comunidades, sempre no sentido da convalidação”.

Salienta ainda que, para a contribuição à conquista deste processo de autonomia, a presença de agentes externos responsáveis, chamados por ele de intelectuais orgânicos, é fundamental.

Temos então, de um lado, um quadro atual de extrema falta de consciência política identificado de uma maneira geral, em grande parte da população dos excluídos no Brasil e de outro, a árdua tarefa atribuída ente outros, aos agentes externos ou intelectuais orgânicos que estão fora desta realidade. Esta situação reflete a necessidade de buscar alternativas para o enfrentamento desta realidade e a necessidade cada vez maior de compreender que tipo de participação estamos buscando.

Sawaia (1999) vai buscar no afeto e nas emoções, caminhos para poder fazer brotar a participação, podendo assim potencializá-la, transformando-a em real participação, ou seja, integrada e em sintonia com o grupo em questão e, a realidade ao seu redor.

Ao analisar o papel da subjetividade na análise da participação social, a autora alerta para o grande perigo que pode haver, principalmente estabelecido pela modernidade contemporânea, que se apossou desta dimensão subjetiva buscando transforma-la em objetividade. Exemplos desta situação podem ser vistos, através do discurso de empresários, da mídia, de políticos e de sendo comum.

A mesma autora, menciona que "é nesse sentido que residem os dois perigos que devem ser lembrados quando se elege a subjetividade para compreender as questões sociais e aprimorar a práxis emancipatória: um, ligado ao caráter fashion da subjetividade que exerce a tirania da moda (...) e o outro advém da lógica que comanda o Zeitegeist ( o espírito da época), a qual subordinam homens, relações e coisas aos interesses meramente econômicos ” (op. cit., p.116).

Fazendo uma análise histórica, Sawaia (2001, p. 117) enfatiza que a preocupação destes estudos está voltada basicamente ao gerenciamento instrumental das emoções, e não a uma preocupação de um processo de emancipação dos homens. 
Coloca que, na virada do século XX, a participação estava mergulhada nessa racionalidade dominante da modernidade.

Até os anos 80, a participação era vista, com ênfase no coletivo, na objetividade e na racionalidade, predominando metodologicamente os indicadores quantitativos. Nesse contexto a participação pressupunha alto nível de conscientização política e social e mobilização coletiva, estando representado pelo pensamento "quanto maior o número de pessoas, maior garantia de participação", não havendo quase espaço para a intimidade.

Sawaia (op. cit.) menciona que, no entanto, a partir dos anos 80, a participação adquire um sentido mais subjetivo, cedendo lugar à preocupação com a individualidade e a afetividade.

"Autonomia, emancipação, e diversidade tornam-se os valores éticos mais aplaudidos e $m$ substituição a liberdade e igualdade. $O$ espaço da participação social perde as fronteiras rígidas e a sua temporalidade deixa de ser delimitada pelas ações políticas pontuais, tornando-se o tempo do cotidiano” (p.118)

Mais recentemente, encontramos nos estudos sobre cotidianidade, ou seja, nas entrelinhas da vida cotidiana dos grupos sociais, um caminho metodológico bastante interessante para visualizar na prática de campo, traços da participação social, afirmando o que menciona Maffesoli (1997, p.198) "nos seus diversos aspectos, o objeto ou, para melhor enfatizar sua dimensão de conhecimento, o mundo 'objetal' favorece a participação".

Dialogando com o que coloca Sawaia (1999) e Maffesolli (1997) acredito que o cotidiano trás em si uma potência imbricada, necessária para fazer emergir a participação: "Há de fato uma potência na massa que ultrapassa cada indivíduo, fazendo-o membro de um 'genius' coletivo, gênio que, a exemplo da deidade, cria a sociedade no seu meio natural e social" (Maffesoli, 1997, p.209)

Sawaia (1997, p.156-7) lembra que a "ação participativa pode e deve ser local, especifica e motivada por interesses pessoais e grupais, mas o horizonte deve ser universal para não se tornar corporativista". Argumenta no sentido de que grupos diferenciados devem desenvolver a capacidade argumentativa. Segundo a mesma autora, capacidade argumentativa é o sentimento de legitimidade para participar da construção de políticas sociais "(...) é a capacidade de defender as 
próprias necessidades, respeitando a dos outros, isto é a habilidade de lidar com a realidade do desejo próprio e do outro, construindo um nós" (op. cit., p. 157).

Neste contexto, o acompanhamento dos grupos de jovens da fazenda Ipanema, tornou-se revelador a respeito de como estas pessoas percebem a participação social, o contexto em que ela emerge e também em como a nãoparticipação social pode ser vista como estratégia de ação.

São muitas as vezes que, nos deparamos com situações em campo, que a falta participação é diagnosticada como falta de interesse em participar de grupos, das atividades coletivas e estímulo.

No trabalho de campo realizado para esta pesquisa, esta situação de nãopartipação social e de desestímulo ocorreram, particularmente, em uma etapa determinada do trabalho de campo, causando um tremendo mal estar e sensação de insucesso no trabalho, além disso, a dificuldade de compreender a razão daquela situação.

No entanto, é possível perceber que diversos foram os motivos encontrados em campo, e que muitos são os fatores que favorecem esta condição 'menos participativa' das sujeitos.

Respaldada por reflexões teóricas pude verificar que esta condição de exílio interior, condição 'menos participativa', pode ser vista sob diferentes ângulos, dependendo do ponto de vista do observador. Mencionarei neste trabalho três características que julgo essenciais para discutir este fenômeno:

a) a não-participação como estratégia de resistência: o silêncio

Por exemplo, podemos chegar a uma comunidade e perceber que alguns jovens e mulheres deste local não fazem parte dos espaços chamados participativos, como o centro comunitário, a igreja, ou o grêmio estudantil, espaços normalmente destinados aos líderes comunitários, indivíduos na maioria das vezes bastante comunicativos e expressivos que em muitos lugares de fato lideram a comunidade. No entanto, estas pessoas, aparentemente inexpressivas, podem estar buscando um outro caminho para o encontro e a troca de idéias e ideais, que seja mais compatível com seu modo de ser e agir e, principalmente onde se sintam participativos de fato.

Para Maffesoli esta condição poderia ser chamada de "corpo-mole do social", ou seja, o autor considera que esta é uma condição de defesa e está relacionada a um 
mecanismo de duplicidade antropológica, que pode ser acionado quase que conscientemente pelo corpo social, dependendo da situação na qual ele está exposto.

Para Maffesolli (op. cit.) existe uma astúcia estrutural e corriqueira no jogo social que está na base da socialidade. Ele acredita que, esta astúcia organizadamente ligada à vida somada ao silêncio, é considerada como meio privilegiado de resistência.

É importante lembrar que, esta condição não significa que as pessoas estão exiladas e por conseqüência paralisadas, absolutamente, segundo o autor, seria apenas um mecanismo de defesa, pois a ação está se dando de alguma forma, não necessariamente, pelos caminhos que normalmente se espera.

Um exemplo desta duplicidade antropológica, pode ser visto em diferentes grupos sociais ao longo da história.

Através de depoimentos colhidos com uma liderança do Quilombo de Ivaporunduva $^{16}$, comunidade quilombola localizada no município de Eldorado no Vale do Ribeira-SP, pudemos perceber, que na época da formação dos quilombos locais de fuga dos negros escravos - que eles, para se comunicar e indicar o caminho e o local onde estava sendo estabelecido um novo quilombo, utilizavam uma linguagem de sinais no próprio corpo, representada por pequenos cortes de tamanho e formato diferentes.

Este exemplo demonstra que, mesmo outras formas de comunicação, senão a linguagem falada, garante uma participação, uma ação legitimada por outros valores éticos, como confiança e solidariedade. Neste exemplo, podemos observar que estava havendo uma revolução dentro daquele grupo social, um plano de ação e a definição de estratégias através de outros canais de comunicação e compreensão.

Deste modo, concluímos que esta duplicidade pode estar presente nos diferentes grupos sociais como um escudo protetor. A falta de opções para se observar esta participação poderia determinar um estado de 'submissão': "a posição última da duplicidade: para sobreviver, deve-se saber avançar mascarado e não se desvelar de nada nem para ninguém, nem a si mesmo" (Maffesoli, 1997, p.100).

\footnotetext{
${ }^{16}$ Depoimento colhido pela autora em trabalho desenvolvido no Quilombo de Ivaporunduva no ano de 2001. Esta comunidade está representada por negros descentes de escravos, e existe a mais de 300 anos no local.
} 
De um lado grupos, portanto, determinados em uma dada comunidade podem parecer pouco participativos se analisados sob pontos de vista convencionais. Em função disso, os grupos sociais optam por dissimular em determinada situação uma inércia aparente como forma de conservação de si mesmo.

Como diria Maffesoli, ao avaliarmos e considerarmos esta situação, estamos presenciando um dos principais aspectos marcantes da pós-modernidade. Trata-se de um retorno ao tribalismo, ou seja, momento em que os indivíduos buscam seus grupos de afinidade para que possam se sentir fortalecidos, garantindo seu direito de participação e cidadania. Esta característica faz com que o corpo social tenha vida e esteja ativamente participativo. Torna-se necessário, porém, visualizar esta forma de participação, "a energia coletiva, a força imaginal do estar-junto busca uma via, fora de todos os caminhos banalizados pelo racionalismo da modernidade, sempre mantendo a ética básica de toda sociedade, aprender a viver, saindo de sí, com o outro (...) Logo não mais um corpo social universal, gerido por regras comuns, o do Estado-nação específico que estabeleceria relações contratuais em seguida com outros Estados-nação específicos, mas pequenos corpos fragmentados, tribos misteriosas, acomodando-se do jeito que podem umas com as outras" (Maffesoli, 1997, p.90).

b) a não participação como reflexo da falta de afeto e confiança

Ainda buscando compreender estas outras formas de arranjos sociais, avaliamos que os aspectos organizacionais de grupos podem estar intimamente relacionados com o "não-racional", ou seja, formas mais amorosas e que levam em consideração outros valores como a confiança, ao se organizar em grupo.

Podemos citar, entre outros, o exemplo da "nova era", movimento de comunidades alternativas no Brasil, que se organizam e se aproximam em grupos por afinidades como, crença em valores religiosos, alimentares, busca por melhor qualidade de vida e por um mundo mais pacífico. Neste caso, não são mudanças que podem ser analisadas pela ótica racional, mas sim, pelo não-racional, ou seja, uma identidade grupal que surge e é legitima, orientada por valores e crenças para uma humanidade diferente.

Nesse sentido, é importante lembrar a diferenciação que faz Durkheim, citado por Maffesolli (1997), quando discorre sobre a solidariedade, fala de dois tipos de 
solidariedade à orgânica e a mecânica, a primeira delas estaria mais ligada a vida cotidiana, ou seja, se dá através dos laços afetivos, que garantem a coesão de grupo, a partilha sentimental de valores, de lugares e de idéias, e, a segunda mais voltada ao organização mecânica das pessoas em grupos. Para o autor a propensão para as pessoas se organizarem não pode ser explicada unicamente pela causalidade ou pelo utilitarismo, mas principalmente, por uma contaminação do imaginário coletivo.

Ostron (1990) acredita que os valores são aspectos fundamentais para a associação de pessoas, e ressalta que a confiança promove a cooperação. Quanto mais elevado o nível de confiança em uma comunidade, maior a probabilidade de haver cooperação. E a própria cooperação gera confiança.

Atualmente temos inúmeros exemplos de associações, grupos de reunião, esportivos, políticos, religiosos. De acordo com alguns autores citados por Maffesoli, a associação em torno deste "não-racional" talvez seja a grande marca da pósmodernidade esta estratégia de adaptação ao qual nos referíamos acima "está intimamente enraizada no corpo social e anima numerosas atitudes individuais facilmente qualificáveis de hipocrisia, covardia e outras apreciações morais".

Outro espaço que tem reunido em torno de si grande mobilização social é a questão ambiental, busquei então trazer para o plano reflexivo o caminho de ligação existente entre o surgimento da participação e as atitudes voltadas à questão ambiental.

c) a não participação e as portas de entrada na comunidade

Outro aspecto que julgo ser importante para a discussão da não-participação dos grupos em trabalhos de intervenção pode estar relacionado às estratégias de intervenção social e/ou as portas de entrada na comunidade.

Refiro-me a necessidade de se conhecer com mais profundidade os grupos distintos que se pretende trabalhar, bem como, os papéis sociais que os diferentes atores desempenham. Este mapeamento faz-se necessário para que se determine a opção mais apropriada para a dar a possibilidade a diferentes atores locais em participar da formação de grupos ou intervenções que possam ocorrer.

Muitas das vezes os agentes externos, pesquisadores ou educadores ambientais, buscam trabalhar com os líderes locais em uma comunidade, ou seja, aqueles indivíduos identificados pela comunidade como líderes, ou por sua 
sobressalência sobre os demais. Em geral, são pessoas que participam nas diversas reuniões organizadas na comunidade e que apresentam poder de articulação e influência. No entanto, a participação destas pessoas pode estar revelando não a realidade da organização social interna da comunidade e sim aquilo que queremos buscar lá dentro para mostrar do lado de fora.

Portanto, quando falamos em diferentes portas de entrada, estamos nos referindo à necessidade de compreender o local estudado e as relações que se estabelecem através de outras pessoas ou grupos de pessoas dentro de determinada comunidade, cuja ação aparentemente não é de liderança ou de representação comunitária.

Acredito que, prestar a atenção em como se entrada na comunidade ou por quais portas e não apenas por uma delas, é uma estratégia essencial que poderia garantir uma maior fidelidade no trabalho, na medida em que se estaria analisando a maneira como a participação ou a não-participação se dá no interior dos grupos sociais.

No meu ponto de vista, caso este cuidado não seja tomado, corremos o risco de estar contribuindo para a consolidação de um circulo vicioso em relação à participação comunitária e a formação de lideranças, ao invés de contribuir para a formação de um círculo virtuoso em torno da questão da participação.

De acordo com Tassara (2001, p.213), "a participação pode, de fato, vir a representar gradativamente uma composição representativa do que deve ser o justo sentido no convívio coletivo, no sentido da manutenção dos direitos de ser diferente". Segundo a autora, este tipo de participação define um compromisso de participação emancipatória e libertadora no sentido da libertação do processo de dominação que, "ao longo da história, se constrói pela imposição dessas regras de convívio definida por grupos minoritários que detêm poder econômico, político ou cultural".

Portanto, a participação está diretamente atrelada à organização social. O modo como as pessoas se organizam confere a forma com que a construção das regras de convívio, bem como o estabelecimento da relação de confiança existente no grupo. 
Ao desenvolver o trabalho com jovens no assentamento rural em questão, busquei compreender a lógica da ação coletiva para a formação de seu grupo de jovens, traduzida na compreensão de suas principais motivações.

\subsection{Formação de grupos e os caminhos para a ação coletiva}

A formação de grupos e seus aspectos de associação estão intimamente ligados a um desejo de ação coletiva, seja ela, voltada a uma ação continuada específica, caracterizada pela duração clara no tempo e no espaço, seja ela uma ação pontual.

Olson $(1999$, p.20) acredita que não há grupos que se unem sem haver um interesse comum, e ressalta que "as pessoas têm interesses comuns no mesmo grau em que participam de uma causa".

O autor referindo-se a teoria tradicional de formação dos grupos sociais, diz que existem duas teorias, a formal e a informal. De acordo com a variante informal, a visão tradicional acredita que, os grupos de uma maneira geral, são fenômenos onipresentes na sociedade humana, ou seja, devendo-se à propensão natural da espécie humana em formar agrupamentos, dando origem a associações e se unindo em torno delas. "Esse instinto também está na raiz das divisões e sub-divisões(...) que se erguem dentro de uma determinada sociedade e ocasionam, conflitos morais e algumas vezes físicos"'(p.29).

Já a variante formal, defende que o aspecto de formação de grupos estaria muito mais ligado ao aspecto de evolução das sociedades industriais modernas de hoje a partir das sociedades primitivas precedentes. "Ela parte do fato que grupos primários (grupos tão pequenos que cada membro tem uma relação face-a-face co os demais, como a família e grupos de parentesco, predominam nas sociedades primitivas"'(p.30).

Weber, citado por Olson (1999), acreditava que a formação de grupos estaria dividida em dois tipos de grupos: o grupo associativo, motivado racionalmente e atraído por interesses comuns, e, o grupo comunal, motivado por laços afetivos e grupais, como é o caso da família.

Estas duas definições nos levam a crer que há diferentes tipos de motivações para a formação de grupos e que estas devem estar ligadas às necessidades 
espontâneas dos indivíduos, para que encontrem identidade no grupo e queiram estar juntos.

Outros aspectos são fundamentais para a formação de grupos, tais como a disposição em compartilhar, a afinidade entre elas, o grau de confiança entre as pessoas, sem necessariamente haver uma relação de causalidade explícita. A organização natural e voluntária deve culminar num 'encontro', onde a identidade grupal, a ligação poderá caminhar para uma configuração durável.

A organização social é o resultado de um número de indivíduos, maior ou menor, podendo ser caracterizada por um sistema auto-organizável natural. Difere, portanto, por estar limitada ou motivada pelo papel dos desejos e finalidades dos indivíduos do grupo. Deste modo, o número de participantes que formam e atuam em um grupo e, conseqüentemente, seu tamanho podem ser determinantes do desempenho e da eficiência da ação coletiva empreendida por ele.

A teoria tradicional de formação de grupos traçava uma diferença entre tamanho de grupo, partindo do princípio de que grupos grandes e pequenos diferem em grau, mas não em tipo, não fazendo nenhuma menção a sua eficiência ou a seu apelo para potenciais membros.

Outros autores, como Ostron (1990) e Putnam (1996) refletem sobre o aspecto dos conflitos na formação de grupos e na ação coletiva por eles proposta. No entanto, farei referência apenas aos aspectos referentes ao tamanho de grupo.

Olson (op. cit.) ressalta que há uma dificuldade clara ao se analisar o tamanho do grupo e o comportamento do indivíduo no grupo. Ele acredita que isso se deve ao fato de que cada indivíduo em um determinado grupo pode conferir um valor diferente ao benefício público almejado por es.

Analisando mais adiante, o autor defende que, em qualquer grupo no qual a participação for voluntária, o membro ao atingir suas vantagens na participação, tenderá a parar de contribuir antes que o benefício coletivo para o grupo tenha sido atingido. Dependendo do tamanho do grupo, esta motivação pode ser maior durante o período em que ele não atinge seu objetivo.

Olson (op. cit.) cita um fenômeno bastante observado, o fenômeno do freerider, ou seja, o caroneiro. 
Podemos mencionar um exemplo hipotético: reuniões de determinado grupo em que um dos membros está presente, porque deseja receber o benefício coletivo que virá ao final das reuniões. Ele, no entanto, não participa efetivamente em momento algum, pois sua motivação é outra, diferente da do grupo. Esta pessoa está apenas pegando carona no grupo, e, portanto, não estabelece uma ligação real, capaz de criar uma identidade na qual ele se sinta representado. Isso nos faz refletir sobre o tamanho dos grupos de trabalho.

Há autores que defendem que a existência de grupos menores poderia fazer com que todos os membros pudessem sair com benefícios em um tempo muito parecido. De acordo come sta concepção, quanto maior for o grupo, mais longe ele ficará de atingir seu ponto ótimo de obtenção de benefício coletivo, ou seja, quanto maior for o grupo, mais ele promoverá seus interesses comuns.

Referindo-se a história da humanidade, Olson (1999) diz que "sob condições primitivas de organização social, as pequenas unidades, de tipo familiar, respondem por toda ou quase toda interação humana” (p.30).

\subsubsection{Tamanho de grupos}

Simmel citado por Olson (1999), declara que os grupos pequenos podem agir com mais decisão e utilizar seus recursos com mais eficiência do que os grupos grandes: "os grupos pequenos e centripetamente organizados costumam reunir e empregar todas as suas energias permanecem com muito mais freqüência” (p. 66)

Outros autores mencionados por Olson (op. cit.), salientam que há evidências históricas que os grupos menores tem demonstrado muito mais durabilidade ao longo da história que o grande grupo.

Chanberlain (1961) citado por Olson (op. cit.), diz que no nível da tribo ou do grupo pequeno, as sociedades sempre conseguiram se manter coesas. Em outra passagem, referindo-se ao regime político, o autor menciona, que os regimes socialistas ou quase-socialistas só foram possíveis em grupos muitos pequenos e, complementa, dizendo que sempre falharam nos grandes".

$\mathrm{O}$ autor salienta que, em grupos grandes o participante típico, quase sempre, não tem consciência que seus esforços individuais podem influenciar muito no 
resultado final e de que ele será afetado da mesma maneira pelas decisões da reunião, portanto deveria empenhar-se em estudar o tema em pauta. Deste modo, este participante, poderá não se dar ao trabalho de estudar com cuidado o tema em pauta para a reunião. Olson (op. cit.) conclui dizendo que, neste caso, os benefícios públicos para os participantes desta reunião, assim como as contribuições de cada participante para a obtenção de um benefício público maior, diminuirão quanto maior for o grupo.

Por estas razões as organizações recorrem com tanta freqüência a grupos menores, como comitês, sub-comites e pequenos grupos de lideranças, enfatizando que uma vez criados, estes grupos tendem a desempenhar uma papel crucial.

Contudo, o ponto mais importante no que se refere aos pequenos grupos é que alguns deles podem obter uma determinada quantidade de um benefício coletivo através da ação voluntária de um ou mais membros.

A partir de um estudo realizado em 1951, John James, citado por Olson (1999, p.66), descobriu que em uma ampla variedade de instituições públicas e privadas, nacionais e locais, os grupos e subgrupos ativos tendiam a ser muito menores do que os grupos e subgrupos que não agem. Mais adiante, o autor nos conta que, em um dos casos estudado, o tamanho médio dos grupos ativos era de 5 a 6 membros, ao passo que o tamanho dos grupos não ativos era de 14 membros, concluindo que, se se deseja um grupo para ação, este deve ser pequeno. No entanto, se o objetivo for a criação de um grupo onde se buscam pontos de vista, reações, etc este devem ser maior.

Seguindo a tendência apresentada por Mafessolli (1997), apresentada anteriormente, Olson (op. cit.) defende que "no nível do pequeno grupo a sociedade conseguiu coesão. Inferimos portanto, que, para que a civilização se mantenha, ela deve reter alguns traços do pequeno grupo" (p.69).

Para além das teorias tradicionais, é importante lembrar que a formação de grupos e a definição de um tamanho pré-estabelecido, não necessitam ser tão deterministas, uma vez que não se pode negar a existência de grandes grupos organizados além de outras variações que também apresentam uma coesão.

Tudo isso, no entanto, faz-nos refletir sobre a motivação que leva cada indivíduo a se unir em um agrupamento e a manter esta união coesa. No tocante à 
organização e à coesão de grupos, outro aspecto fundamental é a questão do consenso grupal, ou o grau de consenso com que o grupo consegue trabalhar.

Hare (1958) citado por Olson (1999) diz que se houver muitos desacordos sérios, é provável que não haja um esforço coordenado e voluntário. Por outro lado se houver um alto grau de concordância a respeito do que se quer bem como da forma com que se quer obtê-lo, quase sempre haverá ação grupal eficiente.

Desse modo, é importante refletir quando ocorre uma situação que se dá por uma falta de consenso no grupo ou por uma falta de estímulos ou incentivos individuais dentro do grupo. Existem diferentes tipos de incentivos motivadores da participação em grupo, podendo estar mais ligados ao respeito, ao prestígio, à amizade ou a outros fatores de fundo social ou psicológico além de incentivos econômicos.

O mesmo autor coloca que "a possibilidade de que, num caso em que não haja nenhum incentivo econômico para que o indivíduo contribua para a realização de um interesse grupal, possa haver contudo um incentivo social para que ele dê sua contribuição" (p.72).

Mais adiante, ele afirma que "se os membros de um pequeno grupo que tivessem um interesse e um beneficio coletivo comum, fossem amigos pessoais, ou pertencessem ao mesmo grupo social, e algum dos membros tivesse o ônus de prover este beneficio coletivo nas costas de outros, eles poderiam, mesmo que ganhassem algo economicamente com esse tipo de conduta, perderiam socialmente com ela, e a perda social poderia pesar mais na balança que o ganho econômico” (p.72).

Estas considerações apresentadas, podem ser imediatamente aplicadas às experiências práticas que vivi no assentamento, refletido-se, inclusive, nas dificuldades que tivemos ao longo do trabalho de pós-formação do grupo, a fase de acompanhamento.

Fazendo uma comparação entre a fase de ocupação de uma área para assentamento e a formação do grupo de jovens, a pós-ocupação da terra, assim como a pós-formação do grupo são sem dúvida momentos que exigem maior trabalho e coesão grupal para resistir às adversidades do caminho, tornando-se fundamental enaltecer os incentivos sociais, assim como a construção e o respeito aos valores que regem este grupo. 
No caso do assentamento em questão, poderemos ver mais adiante que a existência de diferentes grupos pequenos que atuam motivados por diferentes objetivos dentro do assentamento são formas que a comunidade desenvolveu para poder expressar-se. Estes grupos definem e estão regidos por normas, valores e instituições ${ }^{17}$. No entanto, estes subgrupos devem ter conhecimento da 'energia social' em que estão inseridos, caso contrário, perdem a noção do conjunto e da ação integrada, correndo o risco de agir isoladamente num movimento contrário aos rumos gerais desta coletividade ou, ainda, sob a ação da dominação de um dos pequenos grupos.

Para que possamos consolidar esta análise, acredito ser fundamental incluir a dimensão afetiva, já mencionada anteriormente, que pode ser vista nos diferentes grupos sociais e na forma de como ela se relaciona ou influencia as atitudes e a própria existência do grupo.

Sawaia (1999, p.98) já mencionada anteriormente, apresenta a afetividade como uma ferramenta essencial para compreender a situação social dos indivíduos, definida como "a tonalidade e a cor emocional que impregna a existência do ser humano se apresenta como: 1) sentimento: reações moderadas de prazer e desprazer, que não se refere a objetos específicos e 2) Emoção, fenômeno afetivo intenso, breve e centrado em fenomenos que interrompem o fluxo normal da conduta".

A autora esclarece que muitas vezes este conceito é visto negativamente, como fonte de desordem, empecilho para a aprendizagem, atributos que segundo ela, se cristalizaram ao longo do tempo. Esta visão ultrapassada contribui para dificultar a compreensão de como as pessoas se relacionam com o social (família, trabalho, lazer e sociedade).

Sugere ainda, que a emoção deve ser pensada positivamente, como parte do pensamento e da ação, coletivos e individuais, bons ou ruins, constituindo-se na matéria-prima básica para compreender a condição humana.

\footnotetext{
${ }^{17}$ Instituições são compreendidas neste trabalho, como o conjunto de valores e normas, definidos pelos membros de determinado grupos social, que orientam as ações e atitudes do grupo.
} 
Mencionando Espinosa, ela nos apresenta a hipótese seria de que "a paixão constitui caminho à compreensão e ao combate da servidão e tirania, pela sua positividade, pois ela é base da ética, da sabedoria e da ação coletiva democrática, tornando-se negativa, quando associada a ignorância e superstição" (Sawaia, 1999, p.100).

Finalmente, ressalta a importância de se considerar que a mente faz parte do corpo e como tal é matéria emocional e social.

Dentro do contexto deste trabalho, faz-se necessário compreender um pouco melhor o tema assentamentos rurais e os processos de transformação no campo. Portanto o tema a seguir, buscar'r elucidar estes elementos.

\subsection{Assentamentos rurais e a necessidade de uma transformação agrária}

O tema reforma agrária, desde o início da década de 60, tem sido um tema controverso e explosivo no Brasil, envolvendo diferentes compreensões acerca da problemática rural, por parte dos órgãos e instituições envolvidos.

A maneira como que vem sendo trabalhada ao longo dos anos, requer que se tenha uma boa distinção entre a necessidade de uma reforma agrária e de uma transformação agrária. Considerando que no Brasil, esta luta, muitas vezes travada por sucessivos governos ditatoriais, apesar de algumas iniciativas existentes no decorrer da história da política brasileira, tem avançado na conquista de um processo de democratização no meio rural.

Temos, neste caso, um cenário bastante complexo. Através de uma leitura mais simplista, há de um lado, o monopólio da terra nas mãos de pouquíssimos proprietários rurais, o que constitui não somente uma fonte de poder econômico, como também de poder social e político. Do outro lado temos milhares de trabalhadores rurais vivendo um penoso processo de ex-propriação da terra que vem desde a colonização brasileira até os dias atuais.

Além disso, somam-se a eles milhões de trabalhadores rurais de pequenas propriedades familiares, que pouco a pouco, não conseguem mais resistir a difícil luta cotidiana pela sobrevivência, que saem a procura de emprego, engordando os cordões das grandes periferias de centros urbanos. Este 'apelo' da cidade, de um emprego assalariado, da necessidade de suprir as demandas básicas como 
alimentação e saúde, motivados pela falta de incentivos de recursos governamentais, os ex-agricultores buscam novas geração de renda.

Aos que sobrevivem no campo, a situação não é tão distinta, a falta de assistência gera uma dinâmica de vida no campo que se traduz em um círculo vicioso de dependência governamental e inatividade, formando assim uma dinâmica perversa que produz miséria, distorce e destrói a natureza.

Como bem lembra Gonçalves (2000, p.12) "A expulsão dos homens $e$ mulheres da terra é o nome do des-envolvimento. A terra, a natureza, passa a ser, cada vez mais, uma mercadoria comprada e vendida. Os homens e mulheres semterra desterrados (as), sem poder dispor da natureza, cada vez mais tornada propriedade mercantil, migram para as cidades onde vão encontrar nas gôndolas dos supermercados, a energia (o alimento) que antes produziam por si e para si mesmos".

Torna-se, portanto, essencial que agentes sociais do governo e a sociedade civil compreendam este processo de descentralizar a terra, a Reforma agrária, como uma mudança muito mais ampla, indo além de meros projetos de desapropriações e assentamentos humanos, discutindo realmente a questão social no campo e seus diferentes aspectos.

É necessário ter em mente que "Uma concepção adequada de desenvolvimento, deve ir muito além da acumulação de riqueza e do crescimento do Produto Interno Bruto e de outras variáveis relacionadas à renda (...) deve estar relacionado sobretudo com a melhoria da qualidade de vida" (Gonçalves, 2000, p.29).

Dentro deste contexto da Questão Agrária, não podemos deixar de trazer a tona aspectos definitivamente influenciadores para os rumos da agricultura brasileira, e por assim dizer, determinantes de uma cultura produtivista que continua gerando cada vez mais conflitos na busca pela segurança alimentar de um país.

Nos referimos à chamada modernização conservadora da agricultura brasileira, processo que visava o 'progresso' no campo, ou seja, a incorporação dos processos de modernização tecnológica que não contemplavam mudanças na área sócio-ambiental. 
Leite (1995, p.137-152) citado por Linhares \& Silva (1999, p.190) sintetiza com bastante clareza os aspectos referentes a esta modernização: "a adoção do padrão tecnológico moderno, baseado principalmente no binômio química mineralmecanização; aumento da produção e da produtividade, sem correspondente aumento de renda dos trabalhadores; manutenção da estrutura fundiária, com aumento da tendência a concentração; expansão do crédito rural, privilegiando grandes produtores localizados na região Centro-Sul; formação dos CAI's $^{18}$, com ampla integração industrial, inclusive de setores agropecuários e a integração do capital financeiro com os capitais agroindustriais e agrocomerciais; transformação dos bens agrários, terra e gado principalmente, como resultado dessa integração, em poderosos ativos financeiros, homogeneizando as taxas e interesses do capital no campo e na cidade; territorialização da burguesia, com investimentos maciços de grandes grupos financeiros e industriais em terras, sob a cobertura de incentivos fiscais dados pelo Estado. E a internacionalização da agricultura brasileira, com a entrada em grande quantidade de vários itens, além do café, no comércio mundial (soja, laranja, sucos, aves, enlatados, etc.).

Essa modernização, realizada, como bem lembra o autor, sem que fosse alterada a estrutura da propriedade rural, teve, como dizem os economistas, 'efeitos perversos'. De acordo com Palmeira \& Leite (1996, p.16), "a propriedade tornou-se mais concentrada, o êxodo rural acentuou-se, aumentou a força de trabalho nas atividades agrícolas, cresceu a taxa de auto-exploração nas propriedades menores, piorou a qualidade de vida da população trabalhadora do campo, agravaram-se as condições ambientais". Daí a expressão "modernização conservadora".

De uma maneira geral, a modernização da agricultura surge dentro de um contexto político, em que o Estado exerce um papel controlador e a Reforma agrária passa a ser vista com uma das políticas sociais necessárias.

Alguns autores como Abramovay (1998) mencionam o caráter de resistência da pequena produção frente a esta modernização. Bergamasco \& Kageyama (1996) mencionam a importância da agricultura familiar nos assentamentos rurais, não só para o suprimento de alimentos básicos para o país, como também para a sobrevivência e manutenção dessas famílias. Melo (1998), em seu trabalho de

\footnotetext{
${ }^{18} \mathrm{CAI}$ 's refere-se aos complexos agro-industriais.
} 
mestrado, analisa o desenvolvimento local na região de Conceição do Araguaia- PA. A partir do enfoque da reestruturação fundiária, ele nos mostra a importância da presença dos assentamentos para a economia local.

Apesar destas constatações, temos ainda, grandes dificuldades quando se trata da apresentação de alternativas para um desenvolvimento rural mais democrático, uma vez que estas se chocam com a estrutura fundiária desta modernização.

Como podemos ver, há efeitos, da já mencionada modernização na agricultura, que se refletem diretamente sobre o pequeno agricultor alterando as condições de vida no campo, afetando as relações sociais bem como a estrutura organizacional. Este tipo de mudança acabou por estimular o êxodo rural ou como sugere Palmeira \& Leite (1996) e a ex-propriação da terra. É bem verdade que este processo de ex-propriação, em termos históricos ${ }^{19}$, antecede a modernização da agricultura, sendo, portanto, reforçado por ela, tornando-se mais um de seus efeitos. Outro deles, que contribuiu para a migração e para a complexificação desta relação campo-cidade foi a ex-propriação propriamente dita, caracterizada pela falta de condições, agora impostas pela dependência de insumos e modificações tecnológicas do pequeno agricultor.

O caráter geral desse processo no campo aparece com maior visibilidade quando "a própria reprodução da pequena propriedade estável no sul do país começa a ser ameaçada pela falta de alternativas para as novas gerações, o latifúndio limitando sua fixação como pequenos proprietários na própria região e reduzindo-se as possibilidades de migração para o centro ou o norte; mas também pelo seu endividamento junto ao banco e pela inviabilização dos economicamente mais fracos no bojo do processo de competição que se instala com a entrada do grande capital em circuitos sobre os quais, anteriormente, os agricultores tinham um relativo controle" (Abramovay, 1998).

De um modo geral, podemos compreender que este processo causou uma forte limitação de ordem técnica para os pequenos agricultores. Além disso, fica patente o quanto a saída de migrantes das áreas rurais causa desequilíbrios nas estruturas sociais que servem de suporte, à atividade econômica. Como afirma

\footnotetext{
${ }^{19}$ Neste trabalho não pudemos nos aprofundar neste tema. Linhares \& Silva (1999) fazem uma viagem histórica transcrevendo aspectos fundamentais na compreensão da questão agrária no Brasil, em seu livro, "Terra Prometida".
} 
Bourdieu (1966, p.215) citado por Palmeira \& Leite (1996), “A desvinculação do trabalhador de suas condições de produção tradicional, ao mesmo tempo que impede sua reprodução social como colono, agregado ou morador (...) provoca a alteração do 'sistema de posições e oposições sociais "’.

Nesse sentido, Muller (1989) ressalta de maneira bastante clara que, os problemas da não realização de uma reforma agrária no passado, apenas foram complicantes que foram se agravando, ao longo dos acontecimentos no tempo, a situação agrária no país, tal como o nível de êxodo rural, que acaba tendo que ser absorvido pelo setor de serviços nas cidades, visto que o padrão de acumulação agrícola impõe novas formas de produzir e escalas de produção incompatíveis (na sua modernização) com o nível de produtividade do pequeno agricultor.

Ë importante salientar que, vemos na ex-propriação da terra não apenas um caráter negativo, mas também uma possibilidade de mudança e crescimento justamente determinada por esse nova condição. Sterci (1985) mencionada por Palmeira \& Leite (1996, p. 18) diz que "o importante desta situação é também reter que, sendo este um processo que envolve luta, a ex-propriação não tem resultado certo, e em determinadas circunstâncias, a ruptura das relações sociais tradicionais é a condição mesma para que o trabalhador dependente transforme-se num camponês autônomo".

Deste modo, se a saída ou migração de agricultores do campo pode causar certas desequilíbrios na estrutura social e econômica no campo, a expulsão sistemática de trabalhadores num determinado momento da história e em outro sentido, o retorno de muitos agricultores ao campo, marcada pelo surgimento de assentamentos rurais, causaram a necessidade de repensar estratégias de reformas no campo.

Nesse sentido, alguns autores discutem outras formas de se pensar a reforma no campo, a fim de torná-la mais realista. Assim Silva (1987) sugere uma 'reforma agrária social', propondo que a população-alvo seja o 'lumpesinato', população mista, que não encontra mais ocupação no setor urbano e procura um retorno ao campo. Esta definição do autor contempla em grande medida a heterogeneidade vista em muitos assentamentos rurais no estado de São Paulo (Machado, 1998; Branco 1999; Bergamasco,1996). 
Romeiro (1990, p.354) citado por Palmeira \& Leite (1996) acredita que "o sentido atual da Reforma Agrária no Brasil seria ampliar as oportunidades de emprego no campo, de modo a reduzir a pressão da oferta de mão-de-obra no mercado de trabalho urbano-industrial".

Já Linhares \& Silva (1999) definem a Reforma Agrária como "uma necessidade dos trabalhadores para reduzir a concentração da terra, mudar a forma de utilizá-la e diminuir o êxodo rural. Ela nos aproxima de um regime mais democrático, popular. Seria um acúmulo de forças para coisas maiores”.

Silva (1995) citado por Palmeira \& Leite (op. cit.) aponta para a transformação da estrutura do emprego no campo. Segundo ele, nos últimos anos, o crescimento das atividades econômicas não-agrícolas entre a população que reside no campo tem aumentado mais acentuadamente do que as atividades agrícolas propriamente ditas. O mesmo autor defende a 'reforma agrária não essencialmente agrícola', importante enquanto unidade fixadora de mão-de-obra com um mínimo de condição reprodutiva e potencialmente apta ao desenvolvimento de outras atividades off-farm.

Martins (1997, p.183) vê na reforma agrária a possibilidade de modernização do Brasil, não só porque se constituiria em uma forma de desobstruir os caminhos para transformação do país "mas também porque tem possibilidade de abrir um novo campo profissional. Desagrarizar a questão agrária é fundamental para que as atividades rurais possam ser encaradas como profissão, como qualquer profissão moderna".

Nos últimos anos, através da ação dos movimentos de luta pela terra, vimos seguir, algumas ações governamentais que resultaram no assentamento de cerca de 150.000 famílias em todo do estado de São Paulo (Entrevista com Técnico do ITESP-Sorocaba, 1999).

Quando nos referimos aos movimentos de luta pela terra, estamos falando especialmente do Movimento dos Trabalhadores Rurais Sem Terra, o MST, que surgiu na década de 90, constituindo um dos maiores movimentos sociais do país, definido por Gilmar Mauro, um de seus principais representantes, como um movimento cujo "o objetivo básico seria a integração de uma parcela dos excluídos ao processo de cidadania. Esta é a revolução que a Elite rural teme. Não é preciso 
pegar em armas(...) nós mantemos a utopia, cada militante sabe que está fazendo uma revolução dentro dele mesmo".

No ano de 1999, no Estado de São Paulo, o MST estava composto por 150 mil famílias, distribuídas por 168 acampamentos, nos quais pelo menos 40 mil famílias viviam em barracos de lona. A população sem-terra chegava, nesta época, no conjunto do país, a 4 milhões e 500 mil trabalhadores. O movimento é dirigido por um encontro nacional que se realiza a cada dois anos, com 180 delegados, que escolhem um diretório de 15 nomes de pessoas que vivem em acampamentos, três deles públicos, de acordo com Linhares \& Silva (1999).

Este cenário tem sido considerado como um grande avanço do movimento dos trabalhadores rurais e da sociedade em geral, como um grande progresso, em termos de luta pela terra.

Além disso, a conquista da terra coloca, de imediato, os desafios da reorganização social e reestruturação das atividades, após o assentamento das pessoas. É importante lembrar que o processo de ocupação de uma área é o primeiro passo para a conquista da terra, que, na maioria das vezes demora, em média de 5 a 10 anos para se regularizar, neste meio tempo, as famílias vivem em condições de incerteza total sobre seu destino.

No caso do assentamento estudado na Fazenda Ipanema, desde a ocupação até o ano 2000, a situação fundiária dos lotes ainda não estava totalmente resolvida, completando-se, portanto, cerca de 8 anos de luta pela regularização definitiva das terras.

Esse processo de indefinição e de incertezas gera no momento da pósconquista da terra diferentes conflitos e dificuldades não só entre os assentados, mas também na sua relação com outros atores sociais que fazem parte deste cenário, como os órgãos governamentais, órgãos não-governamentais e outros que atuam no local.

A conquista da terra não é o fim, mas um começo na definição das políticas de reforma agrária, de crédito e assistência técnica. Há grande fragilidade na permanência destas pessoas no campo, pois, para muitas o assentamento significa o retorno da cidade para o campo e, também, o começo de uma nova proposta de vida. É, sem dúvida, um processo de ressocialização no campo, como afirma Martins 
(1997) e que precisa estar acompanhado de atenção e orientações para o desenvolvimento das aptidões e potencialidades não só do ambiente social e agroflorestal, como também das pessoas e dos diferentes grupos sociais existentes.

É neste contexto que surge o momento 1 desta pesquisa. 


\section{METODOLOGIA}

\subsection{Referenciais metodológicos}

Julguei necessário, explicitar com maior detalhes, as bases conceituais que referenciam este trabalho, assim como os impasses metodológicos que me acompanharam durante este percurso.

Desenvolvi esta pesquisa baseada nos pressupostos da pesquisa social qualitativa, assim definido, em função das necessidades vistas em campo, entretanto faz-se necessário uma breve explanação sobre os caminhos que me fizeram chegar até ela.

Iniciei o trabalho de campo desta dissertação com a forte convicção de que os pressupostos da pesquisa ação-participante eram aqueles que se encaixavam com tudo aquilo que eu pretendia desenvolver no trabalho de campo. Acreditava nisso, muito mais pelo fato de, até aquele momento, já haver participado de alguns pequenos projetos em educação ambiental, e perceber que a $\mathrm{PAP}^{20}$ é fortemente utilizada, do que por realmente conhecer suas bases conceituais.

Ao longo do trabalho de campo, principalmente no tempo 1 desta pesquisa. Dúvidas relacionadas a aplicação e a correta compreensão foram surgindo cada vez mais fortes em relação ao método escolhido, baseados em minhas análises particulares e na avaliação dos próprios trabalhos anteriormente realizados por mim.

Esta metodologia revelou-se, na sua amplitude, susceptível a uma infinidade de conceitos e explicações, que sempre pareciam ter espaço e justificativa. Isto de certa forma, foi guiando minha conduta na coleta de dados e nas observações feitas em campo. Em alguns momentos, eu tinha a sensação de que muitas portas estavam se abrindo, dificultando o foco do trabalho científico.

${ }^{20}$ PAP - Pesquisa ação participante 
Experiências externas vistas em encontros e congressos realizados em torno da Pesquisa Participante eram ao meu ver, algumas vezes esclarecedoras, porém outras vezes complicadoras. Isso porque em torno da proposta aglutinavam-se muitas idéias e muitas propostas. Podia-se ver, em alguns trabalhos apresentados, pelo menos na área da Educação Ambiental, uma certa superficialidade nos conceitos norteadores e muita descrição dos resultados, o que poderia, em alguns casos, estar comprometendo sua análise e a contribuição para o desenvolvimento do método científico.

A partir desta reflexão, tornava-se questionável a forma com que alguns pesquisadores se apropriavam do método e o reproduziam, restando ainda saber se tratava-se de uma impressão a respeito do observado ou não, e neste caso, qual seria o caminho para reforçar esta metodologia, tendo clareza de suas fragilidades e fortalezas, em especial, na área de Educação Ambiental?

Neste rumo nos baseamos principalmente em autores que desenvolvem a Pesquisa Participante como Thiollent (1994), Viezzer \& Ovalles (1994), Sorrentino (1995), Brandão (1984), Barbier (1985) e em metodologias de análise qualitativas como Pathon (1997), Minayo (1994), Ludke \& André(1986) e Rey (1999), além de outros autores que tendo tido experiências de pesquisa-ação, Pesquisa Participante, pesquisa ação-participantes e com métodos qualitativos de coleta de dados, e que puderam levantar e pôr em discussão aspectos extremamente relevantes nas práticas e em seu valor científico.

Viezzer \& Ovalles (1994, p.53) definem Pesquisa Participante como um conjunto de técnicas para pesquisar as causas e conseqüências dos principais problemas das comunidades. Enfatizam que "seu objetivo é o de desvendar, na medida do possível, as distorções que a estrutura ideológica inconsciente produz, lembrando que ela não só se expressa via sistema de idéias, raciocínio, conceitos, mas também está apoiada pelo Estado, pelos meios de comunicação de massa e por outras instituições".

Os mesmos autores, ao analisar projetos desenvolvidos em Pesquisa Participante na América Latina, deixam claro a importância de se compreender esse método e alertam para seus riscos e desafios, tal como, o mecanismo de submissão ou dependência que se forma entre ativistas/pesquisadores e a comunidade. 
Sawaia (1987, p.4), em seu trabalho de doutoramento, reforça este aspecto, salientando a fragilidade de certos discursos em diferentes trabalhos com Pesquisa Ação Participante (PAP).

"uns enfatizam seu lado metodológico, outros, seu aspecto educativo, outros, ainda, o planejamento social e o que é mais grave, segundo quadros referenciais teóricos distintos. Não se encontra unicidade no significado relativo ao método, à técnica, à teoria e nem mesmo às concepções político-ideológicas. Observa-se nela tanto a expressão da contestação como a legitimação do 'status quo' ".

Barbier (1985) menciona que Kurt Lewin (1890-1947), professor de sociologia da Universidade de Berlim, residente nos Estados Unidos, foi o criador da action reserach (pesquisa-ação) e da dinâmica de grupo. Segundo o autor, a pesquisa ação desenvolvida por Lewin pode ser definida como, uma pesquisa psicológica de campo, que tem por objetivo uma mudança de ordem psicossocial.

"Quando falamos de pesquisa, estamos pensando em Pesquisa-ação, istoé, uma ação em nível realista, sempre acompanhada de uma reflexão autocrítica objetiva e de uma avaliação dos resultados”. (Lewin, 1972 citado por Barbier op. cit., p. 38).

Barbier (op. cit.) menciona que os autores anglo-saxões a definem como pesquisa que tem por finalidade contribuir simultaneamente para o alívio das preocupações de ordem prática das pessoas que estão em situação problemática, e para o desenvolvimento das ciências sociais, através da colaboração que as reúna de acordo com um esquema ético mutuamente aceitável, salientado que, a implicação do pesquisador é uma das características do processo de investigação.

$\mathrm{Na}$ época de sua criação a pesquisa-ação surgiu como forma de solução de problemas surgidos com inserção em fábricas nas zonas rurais dos Estados Unidos, cuja mão-de-obra era incapaz de atingir os altos padrões de produção de outras regiões do país.

Logo surgiram diferentes tipos de pesquisa-ação:

- a pesquisa ação de diagnóstico que se caracteriza por elaborar planos de ação solicitados, onde a equipe contrata realiza um diagnóstico e estabelece recomendações. 
- a pesquisa ação participante cuja ação dos pesquisadores envolve prioritariamente, no processo de pesquisa, os membros da comunidade.

- a pesquisa ação empírica que consiste em acumular dados de um trabalho diário em grupos sociais semelhantes, podendo levar em alguns casos a elaboração ou desenvolvimento gradual de princípios mais gerais sobre a realidade estudada. Um exemplo seria a medicina clínica.

- a pesquisa ação experimental que está mais voltada a um estudo controlado da eficácia relativa de técnicas distintas em situações praticamente idênticas. O caso dos experimentos.

No entanto, Lewin desenvolveu esta pesquisa em um contexto do pós-guerra, trabalhando para uma empresa americana, em que havia a necessidade do desenvolvimento de um mecanismo de estímulo junto as operárias da empresa para que elas produzissem mais, através de mecanismo de estímulo e competição.

Barbier (op. cit.) salienta que por outro lado, Lewin ignorou um outro tipo de intenção exercida não por psicólogos mas por revolucionários. Refere-se a aquela intervenção cujo objetivo central é transformar radicalmente as estruturas sociais e política da sociedade de classes, faz este comentário referindo a Marx quando sugere a realização da pesquisa operária realizada pelos próprios operários.

"Enquanto se aguarda que o governo francês inicie uma grande pesquisa sobre os feitos e danos da exploração capitalista, tentaremos fazer uma por nossa conta. Esperamos que os operários das cidades e do campo nos apóiem, sabedores que são de que somente eles podem descrever, com conhecimento de causa, as dificuldades por que passam, somente eles, e não defensores ocasionais, podem remediar com firmeza as calamidades sociais de que são vítimas” (Marx, 1962, citado por Barbier op.cit.)

Barbier (op. cit.) reflete ainda que aí reside uma grande diferença entre a pesquisa ação americana e a pesquisas francesas em ciências humanas aplicadas.

Desta maneira, estava colocada uma preocupação chave: $\mathrm{O}$ que diferenciava os trabalhos na PAP era a forma com que os pesquisadores se apropriavam dela e, principalmente, como suas experiências e histórias de vida se mesclavam a ela para a compreensão e a busca de soluções para determinado problema. 
Comecei, então, a perceber que, se esta era uma metodologia diferente, tínhamos que discutir e clarear os seus fundamentos básicos, demarcar melhor seu território, a fim de traduzir a realidade e as diferentes matrizes de conhecimento (Gonçalves, 2001) existentes nos diferentes grupos étnicos, sociais e culturais, que pudessem ser captadas por este método. Essa preocupação garantiria maior fidelidade para a pesquisa.

Longe de dar a ela uma simples explicação contemplativa, como foi minha reação inicial, via a necessidade de compreendê-la, uma vez que ela estava tornandose, a cada ano que passava (no Laboratório de pesquisa em Educação e Política Ambiental da ESALQ o qual eu fazia parte), uma porta de entrada que encantava muitas pessoas. Vista como uma maneira nova de pesquisar, que poderia estar aliando as diferentes utopias e ideologias ao desejo de contribuir para a construção de uma ciência que contemplasse em sua totalidade os anseios político-sociais de nossa sociedade. O dilema girava em torno do fato, de que ela poderia estar sendo bem compreendida, porém não tão bem utilizada.

A metodologia causava divergências, no seu entendimento, quanto ao rigor científico, os limites entre intervenção e pesquisa, o corte no tempo da pesquisa de campo, a descrição e análise dos dados, as técnicas de coleta de dados devidamente apropriadas, enfim, uma série de questionamentos que surgem e que felizmente vêm sendo trabalhados e discutidos através dos trabalhos de iniciação científica, dissertações, projetos temáticos e grupos de estudos da OCA- Laboratório de Educação e Política Ambiental da ESALQ/USP.

Sawaia (1987) nos traz uma contribuição fundamental para a compreensão das origens deste método, seguindo seu rumo pela história, clareando e definindo suas bases, lembrando que, ao tentarmos caracterizá-la, não é possível ater-se a seus princípios isoladamente. Trata-se, na verdade, de entender o contexto e a história responsáveis pelo seu surgimento.

Seguindo uma compreensão histórica da PAP, Sawaia (op. cit.) ressalta que no Brasil, na década de 70, por influência da política dos Estados Unidos, cujas universidades estavam dominadas pelo espírito desenvolvimentista, fomentava-se os estudos que, caracterizados pela ação prática, propunham-se a ser portadores de mudança. Segundo essa autora, "dentro dessa proposta acadêmica, política e 
ideológica tornou-se moda um estilo de pesquisa, que recebeu o nome de Pesquisa ação e se apresentava como instrumento de adaptação social”.

O surgimento da Pesquisa ação, apresentado por Thiollent (1986), está ligado a um contexto que atrai a prática de movimentos sociais e de diferentes áreas do conhecimento, como educação e sociologia, que desenvolvem pesquisas sociais, desempenhando um papel ativo não só no equacionamento dos problemas encontrados, como no acompanhamento e desenvolvimento das ações desencadeadas em função dos problemas.

Essa autora deixa claro, portanto, que se trata de um método em construção. $\mathrm{Na}$ sua visão, a abordagem necessariamente deve contemplar as questões relativas aos quadros de referência teórica sem os quais este tipo de pesquisa não faria sentido. Além disso, ela alerta para os 'perigos' que este método pode causar.

Goldstein citado por Sawaia (1987) classifica a Pesquisa Participante como resultado da convergência de três vertentes analíticas: a vertente social-militante, que está relacionada à emergência dos diversos movimentos da sociedade civil em países pobres da América Latina; a vertente educativa, vinda da crítica sobre o papel da Educação, tanto de ordem estrutural, quanto revolucionária, configurando-se na busca por alternativas, como a educação popular comprometida com a perspectiva de transformação social e a vertente epistemológica, que se refere à luta empreendida pelos pesquisadores para romperem com a tradição positivista na pesquisa social.

Sawaia (op. cit) complementa dizendo que a Pesquisa Participante desde sua criação, vem se movendo dentro dessas três vertentes, enfatizando que a vertente epistemológica ficou um pouco 'abafada' neste caminho.

Thiollent (1986), ao se referir à delimitação da Pesquisa Participante, deixa claro que seu alcance está no desenvolvimento de trabalhos na faixa intermediária entre o que é designado como microssocial (indivíduos, pequenos grupos) e o macrossocial (sociedades, movimentos sociais e coletividades). Nesse caso, a pesquisa é considerada como um instrumento de trabalho e investigação de grupos, instituições e coletividades de pequeno ou médio porte.

Neste contexto, ela está associada a uma determinada ordem social e política. Como coloca Sawaia (1987, p.13), sua história se confunde com a história dos movimentos sociais do pós-guerra “...movimentos de contestação no campo social, 
político, intelectual e científico, que desencadearam uma mentalidade libertária pelo mundo (...) no Brasil foi adotada por militantes ligados à Igreja católica progressista - que nos anos 70 foi o único espaço possível de crítica no cenário político repressivo".

De acordo com Sawaia (1987), muitos trabalhos sobre pesquisa-participante referem-se ao trabalho de Paulo Freire, que sistematiza esta metodologia e incorpora a ela o reconhecimento do conhecimento popular.

De maneira geral a PAP apresenta três conceitos básicos norteadores: a conscientização, a participação e a ação transformadora. Três princípios considerados essenciais para o desenvolvimento da pesquisa.

Visto isso, acredito que a pesquisa participante tem elementos fundamentais para o trabalho em campo na temática da Educação Ambiental, desde que sejam respeitados seus passos na aplicação prática.

Visto isso, podemos dizer que a pesquisa participante apresenta elementos que contribuem muito para o desenvolvimento da prática de campo nos trabalhos educativos, no entanto, devido a complexidade da realidade social enfrentada, faz-se necessário buscar outras alternativas metodológicas, que possam contribuir para a compreensão dos fenômenos analisados em campo.

Neste sentido, a busca pela pesquisa social qualitativa se fez necessária. Para compreendê-la melhor buscamos em alguns autores, principalmente em Rey (1999) algumas explicações teóricas.

Segundo o autor, de maneira isolada, as primeiras investigações em pesquisa qualitativa surgiram mantendo uma orientação empirista, apoiada epistemologicamente pelo pensamento positivista, estas experiências surgem no final do século XX, levando alguns autores norte americanos a iniciarem suas pesquisas. No entanto, as investigações no tema, se consolidaram através dos trabalhos de Malinowski, Bateson, Mead, Benedict ente outros. De uma maneira geral, o autor, diz que estes estudos forma fundamentais para o início dos estudos etnográficos, o qual realizava um estudo das culturas humanas enquanto uma pesquisa participante.

Apresentava na década de 20 e 30 grande preocupação com a objetividade e a neutralidade, entretanto, a presença dos pesquisador em campo começou a se tornar alvo de profunda reflexão por parte dos pesquisadores, devido a complexidade e 
impactos causados. Esta situação fez com novas alternativas fossem pensadas para a construção do conhecimento. Transitando de uma epistemologia das respostas para uma epistemologia da construção.

Ainda, de acordo com o autor, surge um movimento para tentar buscar novos significados para avaliar a complexidade dada na pesquisa social, que até então, era impossível de ser construída pelas vias tradicionais. Estas novas alternativas levam em consideração a subjetividade como veículo principal.

A idéia central que pode ser analisada está no fato de podermos ficar menos presos ao método, interprestando que ele é apenas um meio e não um fim e de poder mesclar técnicas ou procedimentos que possam contribuir para o desenvolvimento de um trabalho e da coleta de dados em campo.

Segundo Lapassade (1998) autor que defende a multirreferencialidade através da bricolagem intelectual enquanto possibilidade de compreender melhor os fenômenos observados em campo. Acredita ser fundamental para as pesquisas a realização de uma bricolagem. Define-a como uma dimensão muitas vezes oculta, mas essencial nos trabalhos de campo.

A partir da análise de trabalhos de pesquisadores que desenvolvem trabalhos em psicologia social etnográfica, observou que muitos pesquisadores vivem hoje problemas em seus trabalhos de campo, transformando, muitas vezes, seus trabalhos, em área de 'confissões profissionais'. Nesse sentido o autor menciona que, apesar disso, são raros os trabalhos em que estes mesmos pesquisadores descrevem a dimensão da improvisação, da intuição e da astúcia que desenvolveram para conseguir finaliza-lo, e mais adiante menciona, "se ele (o pesquisador) faz, é somente a respeito do início do trabalho: é aí, com efeito, que uma certa bricolagem será mais facilmente tolerada pela comunidade cientifica, que pretensamente vai ler e julgar esse trabalho". (op. cit., p. 127).

Descreverei a seguir os procedimentos utilizados para a realização desta pesquisa. 


\subsection{Procedimentos utilizados}

Os procedimentos utilizados dentro da pesquisa são fundamentais para garantir uma fidelidade de dados e de informações para posterior organização e análise. Portanto optamos por fazer o relato detalhado de cada passo da pesquisa.

É importante colocar que esta pesquisa foi sendo construída a medida em que os fatos novos foram surgindo, a partir de uma inquietude expressa através das perguntas iniciais motivadoras.

Dividimos a pesquisa em dois momentos, são eles:

Tempo 1: que se refere ao momento da observação participante e da intervenção, onde se deu o contato com os jovens do assentamento, o início do envolvimento, a formação do grupo JUMAFI e também todo o planejamento das ações do grupo.

Tempo 2: momento de acompanhamento do desenvolvimento do grupo JUMAFI, momento da ação dos jovens para colocar o planejamento das atividades em prática.

\subsubsection{Procedimentos e técnicas utilizadas no TEMPO 1}

Consistiu na realização do primeiro momento do procedimento da pesquisa, partindo do conhecimento da realidade.

\section{Fase exploratória}

Sawaia (1987) se refere a este como o momento “...de conhecer e se fazer conhecer", de acordo com Thiollent (1985) esse seria o início da fase exploratória.

Este início se dá através da tese de doutoramento de Branco (1999) cujo tema central foi o de estudar e conhecer a identidade dos jovens assentados da Fazenda Ipanema. Optou por realizar seus trabalhos de campo no assentamento Rural da Fazenda Ipanema em Iperó, SP. Conforme mencionado anteriormente, eu havia desenvolvido alguns trabalhos anteriores ali, portanto recebi o convite da pesquisadora para apóia-la em seu trabalho.

A estratégia inicial utilizada, da qual participei como estagiária, consistiu na formação de um grupo de jovens que reuniu cerca de 13 jovens filhos ou parentes das lideranças locais. Essa foi inicialmente a nossa porta de entrada na comunidade.

A pesquisadora optou em realizar suas observações a partir das reuniões com o grupo de jovens. Os encontros eram regulares, aconteciam aos sábados, num local neutro, na área 1 do assentamento, pelo período da manhã. A minha presença e da 
pesquisadora eram constantes, tanto para a organização da reunião como para motivação da mesma.

Houve a preocupação de expor que a formação de grupos fazia parte do desenvolvimento de uma tese de doutorado e que buscava compreender a identidade dos jovens daquele local.

No início os jovens resistiam um pouco a participar, mas logo começaram a sentir-se mais à vontade e a participar.

As reuniões, com os jovens, a princípio, possibilitaram o conhecimento entre eles, a emergência dos anseios da juventude do assentamento de Iperó e, o objetivo comum de se reunir, formar o grupo de jovens. Mais tarde veio o desejo de fazer alguma coisa diferente pelo assentamento.

Através de técnicas diversas como pintura, atividades lúdicas, dinâmicas de grupo, conversas em grupo, eles foram desenhando seus sonhos e desejos, que progressivamente culminou em um objetivo comum: a construção de uma praça para lazer.

Este trabalho durou cerca de um ano, até que o prazo do trabalho da pesquisadora fosse terminado.

Através deste trabalho, o movimento de jovens dentro do assentamento começava a tomar corpo. Estava sendo criado um 'espaço' onde eles pudessem falar e ser ouvidos, mais tarde, concretizou-se com a formação do JUMAFI -Jovens Unidos para a Mobilização da Fazenda Ipanema.

\subsubsection{Observação participante}

Minha participação nesta fase se deu através de uma observação participante $\operatorname{direta}^{21}$. Esta fase foi fundamental para diagnosticar a situação e seu contexto, no qual foi possível realizar algumas pesquisas de trabalho. Para Patton (1980) o propósito dos dados de observação é descrever os dados observados, as atividades que ali aconteceram, as pessoas que estiveram participando, fazer com que o leitor 'mergulhe' na situação.

\footnotetext{
${ }^{21}$ Entende-se por observação participante direta do registro de uma dada informação enquanto ela ocorre, a fim de propor explicações funcionais que se observa (LUNA,1998, p.51).
} 
Para Foot-Whyte (1978) citado por Mello (1998) ao relatar uma experiência como observador participante "a medida em que sentou e ouviu, obteve respostas para perguntas que nem teria feito se estivesse obtendo informações através de entrevistas".

De acordo com a análise de Minayo (1994, p.59) a técnica de observação participante se realiza através do contato direto com o fenômeno observado para obter informações sobre a realidade dos atores sociais em seus próprios contextos. Trata-se de um procedimento em que "o observador estabelece uma relação face a face com os observados" salienta que a importância desta técnica está no fato de podermos captar uma variedade de situações ou fenômenos que não são obtidos por meio de perguntas.

O acompanhamento deste trabalho de pesquisa realizado através das reuniões e encontros $\operatorname{organizados}^{22}$, discussões informais e pequenas contribuições conceituais, foram nos motivando pelo tema.

Ludke \& André (1986), ressaltam que, para que a observação seja transformada em um instrumento válido e fidedigno em uma pesquisa científica, deve ser controlado e sistemático, requerendo planejamento cuidadoso do trabalho e a preparação apurada do observador.

Os mesmos autores apontam algumas desvantagens desta técnica, como a influência que o pesquisador pode ter sobre o fenômeno observado, pois seu envolvimento pode gerar distorções, e até interpretações errôneas do fato.

Luna (1998, p.58) lembra que cada "procedimento de coleta de informações, pelas suas próprias características apresenta uma série de vantagens, mas é limitado em vários outros aspectos. É preciso que o pesquisador tenha conhecimento das desvantagens e, saiba como contorná-las".

Outra fonte de informação foi a dos relatos verbais, que de acordo com Luna (1998) podem apresentar uma série de informações. Para o registro de dados utilizamos o gravador, por haver a possibilidade de se registrar todo o ocorrido numa entrevista ou reunião. Isso não impede que o pesquisador anote e escreva palavraschave que possam auxiliar na memória quando da construção do discurso,

\footnotetext{
${ }^{22}$ Branco (1999) 'tese de doutoramento, Universidade de São Carlos, SP.
} 
auxiliando-no, inclusive, na reformulação de outras questões que não foram cobertas pela entrevista.

Para Quivy \& Campenhoudt (1988) a observação direta engloba o conjunto das operações através dos quais o modelo de análise, que pode estar constituído por hipóteses e conceitos é submetido ao teste dos fatos sendo confrontado com dados observáveis. Seria o momento de validação das perguntas iniciais e da hipótese proposta.

De acordo com os autores, apresenta a vantagem que o pesquisador a utiliza individualmente, sem o envolvimento direto dos sujeitos pesquisados, podendo visualizar o contexto onde se encontram.

No entanto, a definição que Lapassade (1998:135) apresenta para a observação participante é a que melhor se encaixa na prática utilizada em campo nesta pesquisa. Denomina de observação participante ativa, "a prática que consiste em encontrar numa instituição um 'papel' que lhe permita melhor observar os fatos, e este papel já está geralmente fixado pela instituição que é o objetivo da pesquisa” No meu caso, enquanto observadora do JUMAFI, ao olhos dos jovens, me papel, naquele momento, foi o de assessora técnica na área ambiental.

\subsubsection{Entrevistas semi-estruturadas}

Para Ludke \& André (1986) as entrevistas semi-estruturadas representam um esquema não muito rígido de coleta de dados, que permite ao entrevistador fazer adaptações necessárias. No caso da presente pesquisa, estas entrevistas foram essenciais para a construção da história da comunidade em relação a experiência no trabalho com grupos coletivos, na formação do assentamento e na própria formação do JUMAFI.

Foram utilizadas entrevistas semi-estruturadas para entrevistar os 13 jovens que faziam parte do JUMAFI, jovens que fizeram parte e que se afastaram do JUMAFI (3), as lideranças comunitárias do assentamento (4), pais dos jovens participantes (6) do JUMAFI e jovens que migraram do assentamento (2) e líderes religiosos (2). 
Para o grupos de jovens do JUMAFI foram feitas as seguintes perguntas básicas:

- Como foi para você a participação no JUMAFI?

- O que mais te marcou nesta participação?

- Quais as fortalezas e as fraquezas que você percebeu na formação do grupo?

- Como você percebia o papel das meninas na participação do JUMAFI?

- O que você espera do JUMAFI daqui para frente?

Para os demais entrevistados utilizei perguntas mais abertas, que possibilitavam uma conversa menos formal, visto minha relação de alguns anos de convivência no local. A idéia consistia em ir montando uma história, a partir dos fatos por eles priorizados e vividos, a medida em que a memória ia trazendo os acontecimentos. As perguntas foram as que se seguem:

- Como foi a história de organização do assentamento? Com foi o trabalho no grupo coletivo?

- Como você viu a formação do JUMAFI no assentamento e a participação de seu filho?

- Como você vê a formação do JUMAFI e a religião?

- Hoje, você acredita na organização coletiva?

\subsubsection{Pesquisa Documental}

Utilizamos também fontes secundárias de dados para complementar informações a cerca do universo estudado. Nos referimos principalmente, a dissertações e trabalhos de residência realizados por estudantes da ESALQ-USP ligados, na ocasião, ao GEAR-Iperó e ao Prof. Marcos Sorrentino.

\subsubsection{Notas de campo do pesquisador}

Patton (1980), citado por Mello (1998, p.34), atribui grande importância às notas de campo do pesquisador. No nosso caso, construímos uma caderneta de 
campo, onde eram anotadas as observações, percepções e fatos acontecidos em momentos que não estariam necessariamente contemplados pelas entrevistas ou trabalhos de grupos. O mesmo autor ressalta que "as observações devem conter os sentimentos e reações do observador, relatando sua experiência, inclusive os insights, interpretações e hipóteses preliminares sobre os acontecimentos".

Os dados coletados foram predominantemente descritivos, onde pude atentar para o maior número possível de elementos presentes na situação estudada, visto que um aspecto supostamente trivial podia ser essencial para a melhor compreensão do problema que estava sendo estudado. A preocupação com o processo foi muito maior do que com a do produto.

Ë importante ressaltar que a mistura destes procedimentos foi essencial para ter, a partir de diferentes ângulos de visão, uma percepção a mais rela possível sobre os acontecimentos na realidade social analisada.

\subsubsection{Procedimentos utilizados no TEMPO 2}

O momento 2 surge principalmente a partir da necessidade de dar continuidade as atividades e ao trabalho iniciado com os jovens, fortalecendo o trabalho de grupo. Logo após a saída dos pesquisadores anteriores de campo, os jovens se sentem desestimulados para continuar se encontrando e materializar o sonho que haviam planejado.

É justamente neste momento, que esta pesquisa se inicia. Aceitei o desafio e apresentei como meu trabalho de dissertação de mestrado analisar e fazer o acompanhamento do grupo JUMAFI.

Até aquele momento, os integrantes do grupo tinham feito um plano de ações que compreendiam atividades diferenciadas apresentadas nas planilhas em anexo.

Neste momento exatamente, percebi que várias dúvidas que me acompanharam durante a realização do momento 1 da pesquisa, começaram a aflorar. Um conjunto de dúvidas em relação aos procedimentos utilizados até então para a formação do JUMAFI e até mesmo as idéias de dar continuidade ao trabalho do 
grupo, me faziam refletir sobre a decisão assumida perante os jovens e junto a academia. Apresento a seguir os procedimentos utilizados.

\subsubsection{Grupo focal}

De acordo com (Fontas, 2001) A técnica de grupo focal é bastante utilizada em pesquisa social qualitativa, também chamada de pesquisa exploratória, é principalmente utilizada e entendida como um processo de produção de significados que fornece possibilidade de compreender fenômenos ocultos a observação de sentido comum. Além disso, caracteriza-se por utilizar instrumentos de análise que não estão preocupados em explicitar a quantidade dos fenômenos observados, e sim interpretá-los em profundidade fornecendo detalhes a cerca dos comportamentos sociais e práticas cotidianas.

As entrevistas com grupos focais podem ser utilizadas em todas as fases de um trabalho de investigação. São apropriadas para estudos que buscam entender atitudes, preferências, necessidades e sentimentos. São utilizadas, por exemplo, quando investiga-se questões complexas no desenvolvimento e implementação de programas, como aspectos relacionados a dificuldades, necessidades ou conflitos não claros ou pouco explicitados.

De acordo com (Fuentes, 2001), a escolha de entrevistas com grupos focais como fonte de informação deve ocorrer após a elucidação do propósito da pesquisa e a identificação de quem utilizará as informações. Ë fundamental que haja clareza quanto às informações necessárias, entender as razões de ser de cada uma delas e a sua adequação quanto à utilização da técnica Grupo Focal como forma de coleta de dados.

Segundo os autores (op. cit.) sugere-se que se trabalhe com um número médio de até 10 participantes, de preferência reunidos em um formato de círculo, onde cada participante pode ter visão do conjunto, ouvindo a fala dos demais companheiros. Sugerem ainda que, a reunião não deve ser muito longa, aproximadamente duas horas. A reunião é dirigida por um moderador ou facilitador, que utiliza uma guia de discussão para manter o enfoque da reunião, é promover a participação de todos, evitar a dispersão dos objetivos da discussão e a monopolização de alguns 
participantes sobre outros.Esta guia de orientações deve conter os objetivos do estudo e inclui perguntas de discussão aberta.

"Para determinar cuántos grupos se necesitan, primero es necesario recopilar la información pertinente, generar hipótesis del tema en estudio y continuar la organización de grupos hasta que la información obtenida este completa”. (op. cit., p. 2).

Além do moderador, é necessário que a reunião tenha um relator e alguns observadores, que fazem anotações e, posteriormente, podem complementar as informações coletadas.

Escolhi esta técnica por permitir realizar uma conversa exploratória grupal, que garantisse maior segurança às opiniões dos participantes do grupo e também por possibilitar a reflexão coletiva sobre a continuação da existência do JUMAFI, reorientando o grupo e transformando-os em co-responsáveis pelas decisões futuras a serem tomadas. O roteiro utilizado será apresentado logo adiante.

\subsubsection{Reuniões em grupos menores}

Estas reuniões foram o principal técnica utilizada após a realização do grupo focal. Consistia na visita a cada um dos pequenos grupos para verificar o desenvolvimento, realizar algum tipo de assessoria técnica ambiental nas alternativas de geração de renda escolhida pelo grupo. Esta etapa precedia a fase de acompanhamento dos pequenos grupos. Realizamos também atividades de planejamento, utilizando a técnica 'oficina do futuro' (Instituto Ecoar para a Cidadania, 1997).

\subsubsection{Mapa social da comunidade}

A fim de compreender melhor as relações que se estabelecem dentro do assentamento, e também aquelas especialmente envolvidas com os jovens, realizei um mapeamento social da comunidade. A idéia foi construir um mapa, em que pudessem ser visualizada as relações existentes entre cada um dos grupos presentes 
no contexto na vida cotidiana dos jovens, buscando estabelecer a intensidade da suas relações.

\subsubsection{Acompanhamento dos quatro grupos menores derivados do JUMAFI}

O acompanhamento do grupo se deu através de visitas às casas dos moradores e também em visita de campo, quando da atuação dos grupos, em momentos como comercialização dos produtos, visita às roças, vendas em feiras livres, etc.

\subsubsection{Análise de conteúdos}

Através destas técnicas reunimos o conjunto de informações, buscando captar os dados em campo, sem necessariamente fragmentá-los, ou seja, buscando trazer a verdade dentro e por trás dos fatos da maneira que eles ocorriam em campo. De acordo com Colon (1998, p.156) "as práticas sociais são profundamente indexicais e não podem ser reduzidas a sua decomposição em elementos, feito pelo pesquisador para apreender melhor seu sentido".

Minayo (1998, p.75) cita a análise de conteúdos como uma das formas de se apreender as diferentes vozes do grupo com o qual se trabalha, para a autora análise de discurso está compreendida como um conjunto de técnicas que tem duas funções principais: a verificação de hipóteses e/ou questões "através da análise de conteúdos podemos encontrar respostas para as questões formuladas e também podemos confirmar ou não as afirmações estabelecidas antes do trabalho de investigação (hipóteses) e a outra está relacionada a descoberta que está por trás dos conteúdos manifestos "...indo além das aparências do que está sendo comunicado".

Ardoino (1966) citado por Colon (1998, p.155) chama este tipo de análise de dados de análise complexa, e complementa "seria a combinação de conjuntos profunda e irredutivelmente heterogêneos, que permitirão a elaboração de novas significações. O trabalho de análise consiste então em procurar localizar estas significações e articulá-las". 


\subsubsection{Triangulação de dados}

Esta técnica consiste na combinação de diferentes perspectivas metodológicas quanto forem necessárias para a realização de uma pesquisa de campo, no estudo do mesmo fenômeno.

No processo de pesquisa proposto, o levantamento das categorias de análise será realizado a partir da coleta dos dados, análises e dos grupos de jovens, através do processo denominado de "triangulação dos dados"( Triviñus, 1987, p. 139-40).

De acordo com o mesmo autor, existem diferentes tipos de triangulação: de dados, de investigador e de metodologia.

Neste caso, os dados coletados através dos procedimentos anteriormente descritos, serão triangulados com o objetivos obter maior amplitude na descrição e compreensão do foco em estudo. Para isto, as bases conceituais e teóricos, bem como, técnicos são essenciais. 


\section{RESULTADOS E DISCUSSÃO}

\subsection{Resultados obtidos no tempo 1 da pesquisa}

Através da análise dos dados coletados e dos procedimentos descritos, bem como, do cruzamento entre eles, foi possível, compreender a história de formação do assentamento, a organização social dos grupos da comunidade e suas relações com o grupo de jovens.

\subsubsection{História do assentamento da Fazenda Ipanema em Iperó.}

De acordo com o relatório de Schuler (1995, p.3) “A Fazenda Ipanema está localizada em Iperó, região de Sorocaba, possui uma área de 7.520 ha abrigando terras de três instituições: a Floresta Nacional de Ipanema, administrada pelo IBAMA (Instituto Brasileiro de Meio Ambiente e Recursos Naturais Renováveis), com 5.810 ha; o projeto ARAMAR, da Marinha Brasileira, com 879 ha; e uma área do Ministério da Agricultura e Reforma Agrária (MARA), com 831 ha. Até maio de 1992, ali estavam o Projeto ARAMAR e o restante da área pertencia ao CENEA (Centro Nacional de Engenharia Agrícola) sem uso, devido à desativação deste órgão no início do governo Collor". No anexo 1, se encontra mapa de localização da área.

No ano de 1992, a Fazenda Ipanema, havia sido determinada, pelo governo federal, área improdutiva, destinada a assentamentos de Reforma Agrária. (Moitinho, 1994).

O MST- SP, preparava uma série de ocupações de terra no estado. Haviam famílias, esperando por terras a algum tempo.

$\mathrm{Na}$ madrugada do dia 16 de maio de 1992, a chegada de vários ônibus e caminhões com homens, mulheres e crianças marcava a 'ocupação' da Fazenda por cerca de 800 famílias mobilizadas pelo MST. Tratava-se, segundo relatos que ouvi 
dos protagonistas desta história, de um momento histórico de coragem e esperança na vida de cada uma daquelas pessoas.

No entanto, no dia 21 de maio, o então Presidente da República Fernando Collor de Mello, através do Decreto $\mathrm{n}^{0}$ 530, criava a Floresta Nacional de Ipanema sob a direção do IBAMA (Instituto Brasileiro do Meio Ambiente e dos Recursos Naturais). Isto significava que todas aquelas famílias deveriam ser despejadas imediatamente do local, pois, de acordo com a legislação para criação Unidades de Conservação, não é permitida a presença de moradores na área.

Iniciava-se aí uma briga entre os recentes vizinhos, IBAMA e MST. Após um ano de negociações entre INCRA (Instituto Nacional de Colonização e Reforma Agrária), MST e IBAMA, foi entregue ao INCRA uma área de 1.148 ha da Floresta Nacional (FLONA), em termos de Cessão de Uso, para o assentamento emergencial das famílias acampadas na Fazenda Ipanema. No ano de 2000, estas famílias eram um total de 150. Algumas delas, inclusive, continuam esperando a efetivação de seus lotes no assentamento.

\subsubsection{O processo de organização social do assentamento}

O processo de organização no assentamento foi bastante marcado pela intervenção e orientação do MST, através de líderes que determinavam a forma como proceder para facilitar o processo de estruturação interna. No princípio, todo o assentamento se organizou em brigadas, para facilitar a divisão de tarefas comuns a todos, tais como a construção dos barracos, a alimentação e o plantio. No entanto, aquelas famílias, vinham de realidades culturais distintas, em que o trabalho coletivo para muitos não era uma prática comum. De qualquer forma, como coloca um dos assentados: "a gente ia ver o que ia acontecer, nós estava começando naquela vida, e então tudo era novidade" (líder comunitário e pastor evangélico do assentamento).

Branco (1999, p.61) em seu trabalho de pesquisa, resgata que, na primeira fase do trabalho coletivo para o plantio, começaram as divergências em relação à realização e à distribuição das atividades, o que incluía divisão de tarefas e horários, a distribuição dos produtos e rendimentos do trabalho. 
Havia a determinação superior, ou seja, de técnicos contratados pelo MST para coordenar este momento de formação da comunidade e para um controle dentro do assentamento. A saída e a entrada de pessoas era controlada pelo guarda da porteira (um dos assentados que se voluntariava para assumir tal tarefa). Havia o serviço comunitário para cuidar das crianças, da cozinha, dos consertos nos barracos, da ambulância, das contas, do dinheiro e da distribuição da produção. De um modo geral, todos estavam em condições semelhantes e lutavam pela mesma causa: a conquista de um pedaço de terra.

Esta proposta socializada e democrática de definição das atividades era novidade para muitas das pessoas ali presentes, e naquele momento, acreditavam ser um caminho justo na construção do novo espaço. Para as lideranças que já faziam parte do MST e que fizeram parte de todo o trabalho de mobilização das famílias em diferentes cidades do entorno, a nova experiência representava a concretização de um sonho. O principal líder local do MST, conta detalhadamente, ao ser entrevistado, a alegria e esperança daquele momento. "Nos acreditava naquilo, era a chance que as coisas dessem certo pra toda a aquela gente”. Acreditava na forma de organização social proposta e acreditava nos idéias do movimento como coloca saudoso, o líder local.

Os jovens, naquela ocasião, contribuíam no trabalho de plantio e nas tarefas domésticas, parte essencial de mão-de-obra das famílias.

A intervenção do MST, no entanto, estava sendo conduzida por técnicos contratados pelo MST para coordenar o processo de organização interna. Deveriam atuar como facilitadores do processo, porém, segundo depoimentos das lideranças envolvidas neste processo, atuavam mais como determinadores das atividades ali desenvolvidas.

Esta situação começou a gerar, quanto ao esquema rígido de obediência às normas estabelecidas, alguns incômodos e inquietudes em alguns grupos. Machado (1998) descreve muito bem este momento de organização em seu trabalho com os agricultores no mesmo assentamento. Como já mencionado anteriormente, a heterogeneidade da origem das pessoas que estavam ali reunidas, com diferentes costumes e formas de fazer e conceber a agricultura e a própria forma de 
organização, com desejos e expectativas diferentes, começava a entrar em choque com a dinâmica estabelecida pelos líderes.

Alguns depoimentos, colhidos entre os assentados, são bastante ilustrativos deste fenômeno:

"nós que era o povo da igreja evangélica, quase fomos mandado embora, despejado porque nós pensava diferente deles" (líder comunitário e pastor evangélico da comunidade). ${ }^{23}$

"Nós num é contra o MST, mas as liderança que tem aqui dentro é que prejudica, é desacreditado, ninguém confia”. (assentado)

Machado (op. cit.) descreve a história dos indivíduos em relação a organização social dos assentados em três fases: as histórias dos sujeitos antes da ocupação, sua participação na formação do grupo social e, finalmente na consolidação desse grupo.

$\mathrm{O}$ autor reforça o caráter de heterogêneo da comunidade. Havia pessoas provindas de diversas regiões do estado como Iperó, São Paulo, Sorocaba, Campinas, Piracicaba, Limeira d'Oeste, Leme, Sumaré, Indaiatuba e Americana, como também de outras partes do Brasil como Paraná, Bahia, Recife. Os trabalhadores quando não desempregados exerciam diferentes funções. Eram agricultores, agricultores assalariados, metalúrgicos, vendedores, carpinteiros, pedreiros, etc.

Ë necessário destacar que, a maioria dos assentados teve suas raízes na agricultura e foram, ao longo das diferentes crises da agricultura brasileira, vítimas do êxodo rural.

Os problemas que surgiram logo após a fase de ocupação da Fazenda, foram ganhando força maior após uma discordância na divisão do dinheiro de uma produção coletiva. Este fato acarretou traumas quanto a organização coletiva, terminaram em divisões de grupos e desconfiança.

Segundo um assentado que é pastor evangélico, naquela ocasião todos trabalhavam em grupos para as diferentes funções no assentamento e havia uma grande expectativa em relação ao primeiro plantio coletivo, o plantio de melancias. A produção foi toda coletiva, todos participaram, de maneiras diferentes. Segundo sua

\footnotetext{
23 Entrevistas gravadas durante o ano de 1999, com diferentes lideranças comunitárias do assentamento.
} 
esposa, o tempo havia passado e a espera era grande, "era o primeiro dinheiro grande que a gente ia ganhar".

Segundo depoimentos, havia um responsável pela comercialização no assentamento e que fazia negociação com os compradores. Chegado o momento da colheita, caminhões de melancias saíram dali, o excedente da comercialização era dividido entre as famílias. No entanto, ocorreu um final trágico para a empreitada, a pessoa responsável pelas vendas da produção, fugiu e levou todo o dinheiro consigo, gerando um sentido de tristeza e desconfiança muito fortes. Um processo grande de descrença no coletivo, de crise interna e de desconfiança começou a se espalhar entre os diferentes grupos, levando muitos a tomar decisões drásticas, como a própria saída do assentamento. Em outros casos, brigas com as lideranças e entre famílias. A coordenação local, segunda depoimentos que dela colhi, se via obrigada a tomar algumas decisões para reanimá-los e tentar manter a ordem.

Esta situação deixava exposto, o grau de fragilidade existente nas relações que estavam sendo construídas e também o grau de confiança das pessoas em relação à esta nova experiência.

O cenário, não era dos mais favoráveis, a vida cotidiana com as dificuldades básicas típicas de um acampamento, a falta de condições mínimas para a sobrevivência, o desconhecimento entre as pessoas, a falta de água, luz, etc. eram fatores que somados, resultavam num descontentamento geral.

Como poderá ser visto mais adiante, em entrevistas com os jovens, este episódio não se constituiu numa situação isolada. Foi absorvido nas atitudes dos agricultores com relação ao MST, marcados por um distanciamento da regional do movimento e pela reprodução desse olhar traumatizante que nega qualquer chance de atividade em grupo através dos filhos.

Esta postura gerou um grande afastamento dos líderes maiores do MST em outros assentamentos vizinhos, como foi o caso de algumas das lideranças do assentamento de Itapeva, que tinham com Iperó, uma espécie de apadrinhamento. Alguns dos técnicos que trabalhavam pelo MST naquela ocasião, se viram obrigados a sair da coordenação, por pressões locais. Aparentemente, haviam perdido a legitimidade. 
De uma maneira geral, este processo proporcionou o surgimento de lideranças emergentes, outras pessoas que não estavam diretamente vinculadas ao MST, e que, neste momento se sentiram amparadas pelo apoio técnico e organizacional do ITESP de Sorocaba, órgão governamental do estado que prestava assessoria técnica na área de produção agrícola aos assentamentos rurais de São Paulo.

Em entrevista realizada com uma liderança do MST no assentamento de Itapeva-SP, menciona que "esse assentamento (Iperó) é muito difícil de trabalhar, eles não gostam de coletivo”. Segundo ele, houveram muitos problemas na formação do grupo e depois da frustação, um período muito grande de anos sem um acompanhamento e esclarecimento dos fatos que sucederam, e, complementa dizendo, "hoje eles são assim, não quer saber de coletivo, eles são muito individualistas".

A partir de minhas percepções em campo, e a releitura da caderneta de campo, acredito que este fato cristalizou-se no tempo, não tendo sido resolvido claramente. Foi uma experiência difícil, pela carga emocional que carregava, geradora de traumas que se transformaram em fantasmas vivos até hoje.

Essa liderança de Itapeva acredita que, os líderes locais de Iperó, deveriam procurá-los em busca de ajuda, que ao seu ver consistiria em fazê-los compreender que o trabalho coletivo é fundamental para a sobrevivência do assentamento. E sobretudo, que esta é uma das diretrizes básicas do MST para formação de grupos e cooperativas de produção, independente do papel que alguns técnicos contratados pelo MST, tiveram em determinado momento.

Ele complementa suas idéias falando dos êxitos do assentamento onde vive, “A gente já avançou muito, e pra isso, tem que passar por cima de muita coisa, temos hoje a rádio comunitária, financiada pelo exterior, que dá ocupação pra nossos jovens e informa a comunidade. Temos a cooperativa de produção de leite, o grupo de mulheres, tem a fábrica de doces caseiros, a produção de remédios caseiros c'um projeto das plantas medicinais que ajuda as mães da escola, as crianças, dá apoio prós agentes de saúde. Outros grupos tem a apicultura, a produção de mel de abelha, tudo isso coletivo e com a ajuda do movimento".

Conforme mencionado anteriormente, no assentamento de Iperó, o Estado, exerceu papel determinante no segundo momento de organização interna, através da 
intervenção do ITESP - Instituto de Terras do Estado de São Paulo, mantendo inclusive, um escritório em uma área cedida pelo IBAMA para a realização das reuniões do Conselho de Representantes da comunidade, instância máxima deliberativa do grupo.

Essa nova estrutura organizacional, o Conselho de Representantes, existe há aproximadamente 4 anos. Surgiu devido à delicada situação que se instaurou logo após o início da distribuição dos primeiros lotes definitivos. Muitos dos assentados ficaram descontentes com a organização interna do grupo.

Neste momento, surgiram diferentes associações, criadas principalmente devido à necessidade que existiu, em determinado momento, para a aquisição de equipamentos agrícolas pertencentes ao extinto CENEA $^{24}$ e que estava sob a guarda do IBAMA. No entanto, como descreve Machado (2000), na análise em entrevistas com agricultores, essas associações, tendo sido sendo criadas para um fim específico, tiveram, posteriormente, dificuldade de continuar existindo.

Muitos agricultores, por exemplo, não se lembram do nome da associação da qual fazem parte, demonstrando a falta de identidade com seu grupo. A associação que mantém maior contato entre os integrantes é a Filadélfia, ligada ao grupo dos evangélicos, que têm em comum a religião e são bastante unidos. Eles mantém as reuniões periódicas, em que são feitas as discussões em conformidade com as pautas das reuniões do Conselho.

O Conselho de Representantes se reúne periodicamente e está composto por representantes das 05 associações existentes. Os técnicos do ITESP, dois agrônomos, são membros presentes em todas as reuniões e têm papel determinante na tomada de decisões dos assentados.

Atualmente, nem todos os representantes do Conselho participam das reuniões. Há problemas com a representatividade. Três dirigentes entrevistados, membros do Conselho, reclamam dizendo que a responsabilidade sobre as ações e os encaminhamentos sempre sobram para as mesmas pessoas.

Há, também, um pequeno grupo de pessoas que forma a liderança do MST local, basicamente constituído pelo antigo militante do MST, que contribuiu significativamente para a formação do assentamento, sua esposa e outras quatro

\footnotetext{
${ }^{24}$ CENEA - Centro Nacional de Engenharia Agrícola.
} 
famílias. Este líder tem uma trajetória de vida muito interessante, e é a pessoa que mobiliza seu grupo em torno de propostas coletivas. No período de realização desta pesquisa, o grupo ultimamente estava desenvolvendo a criação de suínos e o cultivo de hortaliças, uma pequena área, em regime de cooperativa.

Em entrevista concedida a mim no ano de 1999, deixa entrever a sua crença no trabalho coletivo, apesar das dificuldades.

“ o que nós busca aqui dentro é viabiliza a cooperativa(...) coisa dificil, porque as pessoas não acredita no coletivo (...) esse é o caminho prá melhorar".

"depois de tanto bater a cabeça, pagando do próprio bolso prá tenta monta a cooperativa, nós estamos tentando uma coisa diferente, que tá dando certo, é o trabalho em grupo familiar, pequeno, onde a gente pode ter o controle das coisa mais fácil e a gente tá mais próximo um do outro".

Através deste depoimento, podemos verificar a análise feita pelo dirigente, a respeito do trabalho coletivo, através da própria experiência, ele avalia a necessidade de se criar outros mecanismos para conciliar o trabalho em grupo e a produtividade agrícola.

Mesmo assim, esta liderança, que continua atuante no local, tem enfrentado problemas, sofrendo grande resistência dos demais assentados, ao tentar implementar alguns ideais coletivos, como é o caso, da implantação de uma cooperativa de produção no assentamento.

De uma maneira geral, há grande dificuldade de se estabelecer propostas de trabalhos em grupos coletivos na Fazenda Ipanema, isto muito tem que ver com o histórico traumático da organização social do qual participaram no início das atividades naquele local, somado a outros elementos típicos de uma situação com tamanha heterogeneidade e diversidade de posturas e consciência política.

$\mathrm{Na}$ verdade, o que pude verificar em campo é que não existe pelos demais assentados, uma recusa frente às propostas do MST, no entanto, há uma enorme resistência em relação ao trabalho e as propostas apresentadas por algumas lideranças específicas no assentamento que representam o MST local.

A opinião de dois dos assentados, exprime bem este "desencanto" em relação aos líderes locais e suas diretrizes "nós num somos contra o MST, somo contra a 
liderança dele aqui dentro, que nunca agiu honesto com a gente". (agricultor assentado)

Segundo uma outra agricultora, temos:

"eu devo tudo isso aqui prô movimento, eu fiz parte mesmo, era da coordenação, mais a gente foi decepcionando, teve gente que quis exigir que a gente fizesse de um jeito, trabalho em grupo grande num dá certo, é muita desconfiança(...) sozinho em família vai melhor".

\section{Grupo de mulheres}

Há também um grupo de mulheres, que se formou na época da organização coletiva, existindo desde a formação do acampamento. No ano de 1999, estava sob a coordenação de uma agricultora assentada de uma das famílias da liderança do assentamento, tinha como objetivo principal discutir questões relacionadas a vida das mulheres no assentamento, buscar alternativas para a saúde das crianças e também discutir alternativas para geração de renda para elas.

Segundo ela, as mulheres da comunidade não tinham muita garra para "tocar uma roça junto", iniciaram o projeto da horta comunitária, mas aos poucos o entusiasmo foi definhando, nem todas as mulheres participavam pois haviam dificuldades e a necessidade de uma constância e divisão nas tarefas. Outra tarefa a que o grupo se propôs foi a discussão do estabelecimento de uma escola dentro da comunidade, o grupo se voltou a discussão da necessidade de implantação de uma escola para as crianças e as estratégias que fariam para alcançar este objetivo. No entanto, novamente, se depararam com os problemas de pouca participação das pessoas, o que causou uma desaceleração nos trabalhos propostos.

No entanto, no ano de 1999, através do trabalho de doutoramento de uma pesquisadora da Universidade de Campinas, resgatou-se a idéia do grupo em torno do tema educação, desta vez, com maior força e entusiasmo. Durante o período de duração do trabalho da pesquisadora, o grupo teve momentos de grande participação e freqüência nas reuniões, permanecendo organizado por um período. Esta organização permitiu que outros temas fossem igualmente discutidos e a participação da mulher nestas discussões pudesse ser mais respeitada. Muitos frutos positivos surgiram, porém o grupo sofreu dificuldades e logo após a saída da pesquisadora em 
campo, o grupo praticamente se desintegrou. Algumas mulheres que faziam parte resolveram então continuar o trabalho através de um grupo de trabalho voltado a busca de alternativas para geração de renda local.

No momento da realização desta pesquisa elas estavam produzindo doces e compotas e estavam a frente da construção do centro comunitário da Área 2. Fui solicitada a participar deste grupo em algumas reuniões, para contribuir na organização interna das atividades. Participavam cerca de oito mulheres, entre elas, duas representantes do Sindicato dos Químicos de Sorocaba ${ }^{25}$, no local e a pesquisadora Suzi Rodriguez. Foi uma experiência bastante interessante, pude perceber a diferença e a garra daquelas mulheres em acreditar em novas iniciativas, começar de novo e apostar que juntas poderiam desenvolver algo diferente. $\mathrm{O}$ fato de se reunirem todas as semanas, enfrentando o longo caminho a pé, para chegar aos encontros, a preparação para as atividades propostas, foram elementos incríveis de crescimento do trabalho em grupo, de resgate da auto-estima e de reflexão sobre o papel da mulher na comunidade.

Elas tinham o interesse de conhecer o trabalho de outros grupos de mulheres, para compreender como havia se dado o processo. Para isso, com o apoio do Sindicato dos Químicos para o transporte e dinheiro para o combustível, organizamos juntas uma visita ao assentamento de Itapeva, para ver o desenvolvimento do trabalho do grupo mulheres que existe lá.

A experiência foi muitíssimo interessante, as mulheres puderam ver outra realidade e perceber que outras haviam pensado em idéias semelhantes e principalmente que era possível acreditar e realizar atividades em grupo.

Uma delas, a Josefina, dizia "nós precisa organiza uma excursão grande pra trazer os homens pra conhece tudo isso, e também pra conhece o trabalho das mulheres daqui”.

A participação e o acompanhamento neste grupo, possibilitou-me a percepção bastante significativa do papel da mulher agricultora-assentada enquanto mobilizadora dentro da família e da comunidade. Ao mesmo tempo que demonstra a necessidade de buscar novos espaços na comunidade 


\section{Grupo de evangélicos}

Além desse, outro grupo organizado é o dos evangélicos, que de acordo com dados fornecidos por um dos pastores evangélicos da comunidade, é formado por mais de $50 \%$ da comunidade do assentamento. O grupo tem uma igreja que está em reformas e concentra um crescente número de fiéis, entre eles um bom número de jovens. Este é o grupo que mantém maior organização e freqüência de encontros dentro do assentamento. Há pouco tempo atrás havia apenas uma igreja. Porém, com a dissidência de um dos pastores, há um novo movimento evangélico ainda de pouca expressão.

Não há escolas dentro do assentamento. As crianças e adolescentes freqüentam as escolas existentes na cidade de Iperó e no vilarejo vizinho de George Oeterrer.

A presença do IBAMA, na área vizinha do assentamento, já trouxe uma série de conflitos tanto para o próprio IBAMA quanto para os moradores do assentamento, sobretudo porque o assentamento se caracteriza como entorno de uma Unidade de Conservação, a Floresta Nacional de Ipanema (FLONA de Ipanema). Há uma vila de funcionários dentro da FLONA, a Vila São João, onde algumas crianças do assentamento estudam. E lá também, acontecem os bailes e festas. Algumas agricultoras assentadas trabalham como empregadas domésticas nas casas da vila.

\section{Grupo de comercialização}

Uma iniciativa que até o momento da pesquisa estava dando bons resultados, era o grupo de comercialização. Formado por 4 líderes conselheiros, estava fazendo a comercialização de seus produtos e de alguns outros assentados no CEASA ( Central de Abastecimento do Estado de São Paulo), através da aquisição de uma 'pedra' no mercado, ou seja, um espaço físico, para a comercialização das mercadorias. De outro lado, muitas famílias vendem seus produtos em feiras na cidade vizinha de Sorocaba e nas periferias daquele município, sendo que as duas maiores dificuldades nestes dois casos, têm sido a quantidade e a variedade de produtos que podem oferecer e a falta de transporte para levar os produtos até o mercado.

\footnotetext{
${ }^{25}$ Estas duas mulheres, não eram assentadas, desenvolviam trabalho na área de saúde DST -Aids, junto ao assentamento.
} 
A economia local, para muitas famílias, é de subsistência, havendo também plantio de culturas tradicionais, como milho, feijão, arroz, mandioca, quiabo e maracujá financiados pelos recursos do extinto PROCERA (Programa de Crédito Especial da Reforma Agrária).

Como já mencionado, um dos grandes problemas enfrentados, é a falta de planejamento integrado da produção agrícola e, por conseqüência, da comercialização. Os produtos muitas vezes são vendidos a baixos preços e sem agregação de valor. Novamente, voltamos a questão da organização interna, que nos remete sempre a reflexões.

\section{Organização espacial}

A organização espacial constitui-se de sítios separados. Trata-se de uma opção dos próprios assentados. Após a conquista dos lotes definitivos, eles puderam escolher entre o modelo das agrovilas, onde teriam uma pequena área para a casa e um quintal para a roça de subsistência (plantio de horta, mandioca, plantas medicinais, frutíferas) e o sítio em uma área distante, ou o modelo isolado, que seria construir as casas e as plantações nos lotes definitivos. A maioria optou por se instalar nos lotes definitivos, o que muitas vezes dificulta a comunicação e os encontros entre grupos.

No entanto, como na época de desapropriação da Fazenda, existiam 4 pequenas vila de empregados, estas casas se mantiveram e hoje são pequenas vilas de moradores, onde esses assentados vivem e mantém sua roça em uma outra área.

De todos os grupos até agora mencionados, pode-se observar que, mesmo com aquele histórico de trauma em relação ao trabalho coletivo, muitos agricultores e agricultoras buscaram outras estratégias para conseguir desenvolver suas atividades dentro da comunidade. Buscam organizar-se em grupos menores através das afinidades de objetivos comuns, mas a grande maioria ainda preferiu desenvolver seu trabalho sozinhas ou isoladas, o que pode tornar a busca de soluções dispersa e desordenada. O planejamento integral do assentamento que poderia ser realizado através do conselho de representantes, apresenta-se fraco e pouco representativo de seus grupos, ficando apenas com a solução de problemas imediatos e encontrando grandes dificuldades de planejar a médio e a longos prazos questões maiores que 
permeiam diretamente a vida de cada um dos assentados daquele lugar, como por exemplo, a escola, a juventude rural, a produção e comercialização e fontes de financiamento para a produção agrícola e ambiental. Os aspectos como o de produção/comercialização e organização interna, tem sido bastante influenciado pelo Estado, através da participação e intervenção do ITESP.

\subsubsection{O mapa social da comunidade}

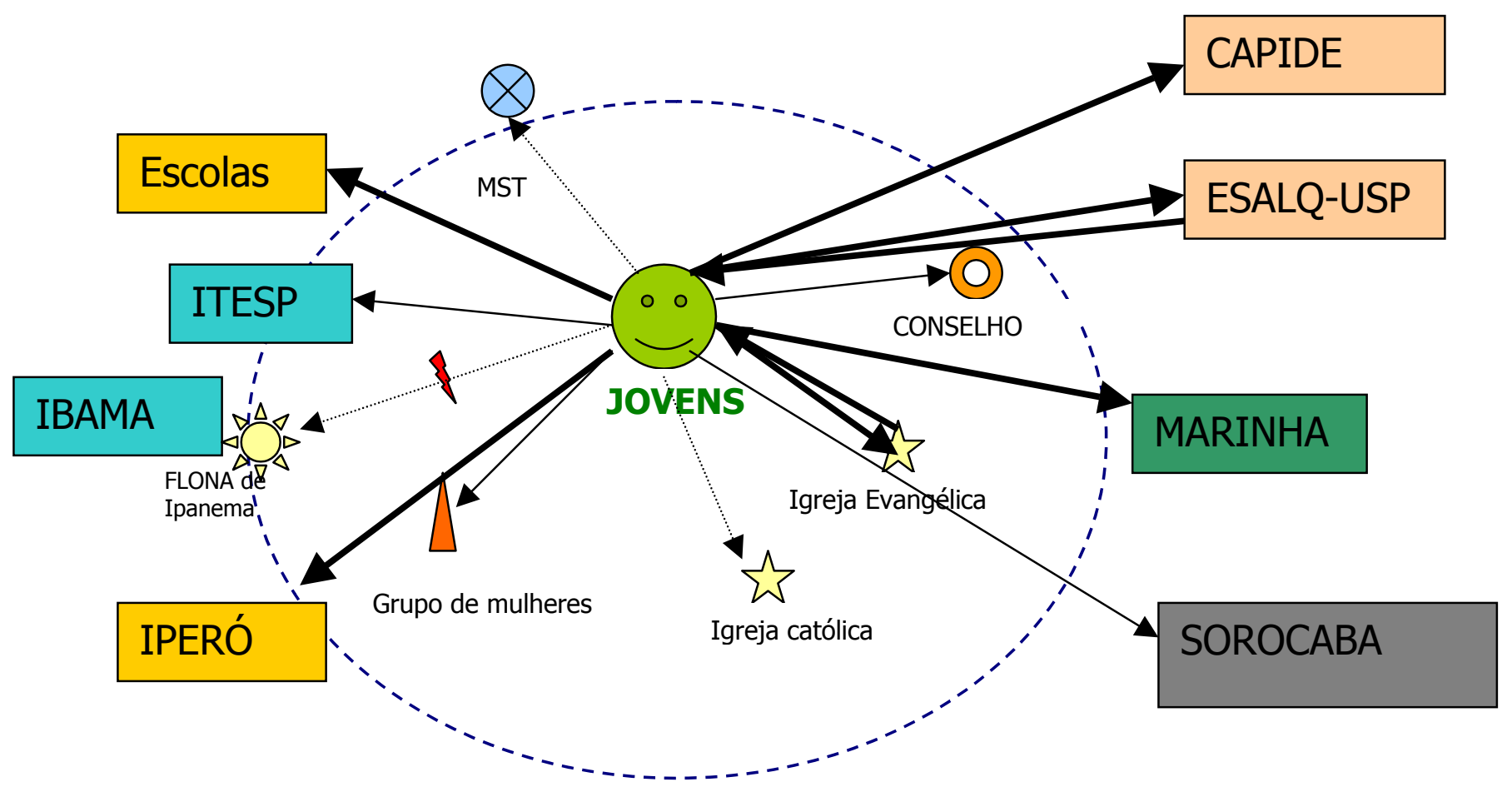

O quadro acima, denominado eco-mapeamento (Large, 1991), nos permite visualizar, de que maneira se dá a presença dos atores locais que apresentam uma interface direta ou indireta com os jovens do assentamento. O círculo azul representa o limite entre a comunidade assentamento e lado de fora da comunidade. Os atores que se encontram sobre a linha limite representam que mantém, de uma maneira geral, maior interação com a comunidade. 
As setas representam diferença de intensidade nas relações estabelecidas entre os diferentes grupos existentes.

$\longrightarrow$ As setas cheias representam que há uma relação entre os dois grupos, porém não muito intensa.

As setas de dupla direção representam uma relação forte entre os jovens e social em questão.

As setas tracejadas representam pouca ou nenhuma relação entre os jovens e o grupo em questão.

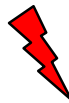

Representa uma relacão conflituosa ente os atores.

- O ator escola faz menção a grande relação que existe, para os jovens, a escola. Visto que não há escolas de primeiro ou segundo graus dentro do assentamento, todos os jovens que freqüentam a escola tem de ir a Iperó ou a George Oeterrer.

- O ator IBAMA representa, mais especificamente, a relação ente a Floresta Nacional de Ipanema, unidade de conservação vizinha do assentamento e que tem mantido relações conflituosas entre a população assentada.

- Iperó é o município onde se localiza o assentamento, representa o centro comercial e local onde ficam as escolas. Para muitos jovens, Iperó representa o local de lazer aos finais de semana.

- O ITESP é o órgão do governo que faz assessoria técnica aos assentamentos do estado de São Paulo. No assentamento, o ITESP mantém uma forte relação com as lideranças locais e posteriormente com um dos grupos de jovens do assentamento que trabalha com produção de mel.

- A CAPIDE é uma ong localizada em Sorocaba que desenvolveu alguns trabalhos junto ao assentamento, e forneceu durante um período específico, capacitação e assistência técnica para três grupos de jovens no assentamento, na produção melífera.

- A ESALQ-USP representa a relação da comunidade coma Universidade, mais especificamente, com o grupo GEAR- Iperó. No período de 1992 a 1999, foram realizadas pelo menos 6 trabalhos de pesquisa (dissertações de 
mestrado, residências e teses de doutorado) e, estágios de vivências, caracterizando uma relação de parceria entre as duas instituições.

- A Marinha aparece com uma relação forte entre os jovens e esta instituição, pelo fato de, freqüentemente empregar, por curtos período, um certo número de jovens como ajudante de pedreiro e serviços gerais em suas obras de construção civil.

- Sorocaba é a cidade mais próxima, o centro de referência para a compra de bens e consumos, é o centro maior de comercialização. Até o momento desta pesquisa, dois dos grupos de jovens revendiam seus produtos (mel e própolis) em uma das feiras livres da cidade.

- O conselho refere-se ao conselho de representantes do assentamento. $\mathrm{Na}$ época do grande grupo JUMAFI, os jovens haviam conquistado um lugar para participar nas reuniões. No entanto, pouco ou muito pouca atenção é dada aos jovens por parte do conselho, caracterizando uma relação de distanciamento.

- No grupo de mulheres participam muito das mães dos jovens que participam do JUMAFI, naquela ocasião os dois grupos encontravam-se na mesma fase de formação e enfrentavam problemas semelhantes. Mais adiante este grupo será melhor descrito.

- O MST representa o grupo de pessoas dentro do assentamento que representa o Movimento no local. Existia pouco ou muito pouca relação entre os jovens e este grupo e também em relação às ações voltadas aos jovens no MST regional.

- A igreja evangélica, até o ano de 1999, estava se transformando no centro aglutinador da juventude do assentamento, atraindo muito jovens. Existem duas igrejas evangélicas no local e uma delas tem um grupo de jovens formado e atuante.

- A igreja católica aparece com uma relação muito fraca entre os jovens do assentamento. Pelo fato principal de não ter um sacerdote presente na comunidade., estando presente apenas quinzenalmente para rezar missas. 


\subsection{Iniciando a jornada: o trabalho com jovens}

Os pesquisadores tinham pouco contato com o assentamento, haviam feito algumas visitas ao local. Seu contato inicial se deu através da visita aos líderes do assentamento com a intenção de trabalhar com os adolescentes do local. Estes indicaram a casa de alguns jovens e o primeiro contato foi feito, através de visitas, em que era feito o convite par participar de um grupo de jovens.

Os jovens se sentiram motivados a princípio, sendo que alguns foram também incentivados pelos seus pais a participarem do grupo.

O grupo começava a se formar. Nesta fase exploratória, os jovens foram se deixando conhecer e, com isso, os objetivos do grupo foram se delineando. Estivemos presentes em vários momentos. Meu papel e o do outro pesquisador estava voltado ao apoio técnico às atividades que fossem surgindo dentro da proposta de ação do JUMAFI.

No momento inicial de formação do grupo, os jovens manifestavam o desejo de estar juntos, fazer algo diferente, ver movimento, criando espaço para os encontros. Apesar disso, algumas dificuldades se fizeram presentes já no início do trabalho, tais como: a longa distância entre suas casas e o local de reuniões, falta de apoio da família, e o envolvimento nas tarefas domésticas, especialmente nas épocas intensas de plantio na roça. Diante desse quadro, a pesquisadora julgou necessário, na ocasião, criar algum tipo de incentivo que favorecesse a participação dos jovens, como facilitar o transporte buscando-os de carro em suas casas para as reuniões.

Nesta fase, pude observar o comportamento dos jovens, a forma de participação e a organização que eles, de diferentes maneiras, representavam nas ações e atitudes cotidianas do grupo.

Os jovens do grupo através das reuniões e atividades propostas, foram assumindo uma postura de 'receptores' dos benefícios que pudessem vir da ação dos interventores. Ao meu ver, talvez estivéssemos construindo uma relação de dependência e, portanto, menos emancipatória.

Exemplos desta situação são:

- a dificuldade de chegar para as reuniões,

- a dependência do transporte, limitando sua participação, 
- pouca iniciativa em assumir o comando do JUMAFI.

Ficava muito claro a demanda dos jovens por lazer e espaço próprio. Eles também expressavam a necessidade de ter uma fonte de renda para consolidar alguns de seus sonhos, além de alternativas de trabalho no campo. Portanto, o "permanecer ali' e esperar que o futuro trouxesse algo melhor era algo incompatível com suas necessidades imediatas.

Partilhávamos o pressuposto colocado por D'Incao \& Roy (1995) que consiste no pressuposto que é necessário"...transformar estes novos agricultores em sujeitos de sua própria realização...propiciar-lhes condições para o aprendizado do exercício da liberdade a que eles aspiram, partindo ao seu desejo de autonomia pessoal e resistir a tentação de uni-los em torno de uma causa fora deles mesmos".

Durante os primeiros seis meses de trabalho em campo, diagnostiquei alguns pontos críticos no trabalho que estava sendo realizado, refleti muito sobre diferentes aspectos que poderiam ser melhor explorados, sobre as estratégias de formação e de intervenção além dos aspectos de motivação em relação ao grupo de jovens.

Sob a orientação dos pesquisadores em cmapo, muitos Êxitos forma alcançados, tais como:

- a realização de cursos de capacitação

- palestras sobre formas alternativas de uso do solo, agricultura orgânica

- concessão de uma área de mata secundária em estágio inicial de regeneração, de aproximadamente 10 há, cedida pelo Conselho, para manejo e instalação de práticas alternaticas de manejo agroflorestal, além da construção da praça

- uma vaga de representação no Conselho de representantes do assentamento.

- Elaboração do estatuto do JUMAFI

- Visitas ao horto florestal

Todas estas conquistas forma extremamente importantes para os jovens do grupo. Porém preocupante era o fato de tratar-se apenas de um projeto de pesquisa, com te pó e espaço determinados. A sustentabilidade da intervenção realizada, estava em cheque.

É importante evidenciar que, o grupo se formou motivado pelo fato de ser um grupo de encontro. No entanto, como todo o trabalho da pesquisadora estava voltado ao desenvolvimento de atividades em grupo, dinâmicas, ou seja, atividades que 
proporcionam expressão de suas idéias, seus medos e anseios em relação a aquela realidade social, os jovens criaram grande expectativas em relação ao trabalho iniciado. A dimensão de tempo, apesar de ter sido mencionada em muitos momentos (o período de 1 ano), não se externava enquanto uma preocupação para aqueles jovens.

O grupo teve muitos momentos de crise, de falta de participação, de dificuldades, no entanto, a possibilidade de criar alternativas para suprir algumas das demandas que eles sentiam, era evidente.

$\mathrm{O}$ fato de estarem reunidos enquanto participantes de uma pesquisa realizada para uma tese de doutorado, apesar de aceita, não parecia estar sendo compreendida como tal, quero dizer, na verdade, o grupo, apesar das dificuldades, estava sendo motivado a pensar na sua realidade, pensar em possibilidades de alternativas de geração de renda, e estavam acreditando naquela nova possibilidade. Parte do trabalho de grupo contemplou a formação do grupo de jovens, a formação de uma identidade de grupo, de um objetivo junto ao assentamento, e também do planejamento das atividades que estariam sendo desenvolvidas por estes jovens.

Depois de concluídas as etapas de formação e planejamento do grupo, esgotou-se o período de trabalho da pesquisadora em campo. Surgiu então a demanda por um acompanhamento do grupo nas atividades que tinham a desenvolver e na sua consolidação. Era um segundo momento, o da ação, da realização de atividades coletivas que colocariam o grupo frente às dificuldades de ação coletiva e articulada.

No anexo 1, apresentamos a formação do JUMAFI (estrutura formal) o plano de ações, a programação das atividades e a divisão de tarefas entre os integrantes do grupo. 


\subsubsection{Preparando o grupo para a ação coletiva}

Momento de fragilidade para a pesquisa. O desejo de ação dos jovens é grande, no entanto, pude perceber que faltava fôlego, estímulo.

As participações nas reuniões estavam cada vez menores, e os pequenos conflitos entre eles no trabalho de grupo, transformaram-se em grandes dilemas.

Através das observações, pude perceber que outros elementos que brecavam sua participação e o processo de autorização, ou seja, tornar-se autor das propostas organizadas pelo grupo.

A partir daí restava a pergunta: O planejamento das atividades havia sido feito por eles e a tempos, via-se que os jovens almejavam um momento de colocar em prática seus ideais, os planos. No entanto, quando de fato eles poderia se apropriar daquilo que foi conquistado para eles, o que tinha era uma atitude de desinteresse e apatia, causando extremo desânimo. O que no início era uma participação tão espontânea e desejada, agora quando a tarefa cabia a eles, a motivação havia desaparecido.

Por razões diversas estes jovens, não estavam conseguindo perceber o quanto tinham avançado em relação ao início do trabalho. Tornava-se necessário fazer uma retrospectiva e levantamento dos aspectos positivos do grupo, trazendo com isso, novas possibilidades de continuidade. Era o momento de uma pequena avaliação.

É neste contexto que surge o TEMPO 2 da pesquisa.

A idéia foi dar continuidade às atividades iniciadas dentro do JUMAFI,. De acordo com o programado, deveríamos estar dando continuidade ao acompanhamento das atividades propostas e trabalhadas na pesquisa anterior, visando a questão ambiental, a parti de uma perspectiva maior de integração e compreensão das questões ambientais do assentamento, tais como, o destino do lixo, novas formas de cultivo da terra, alternativas para jovens, a discussão do tema juventude rural dentro do assentamento e a própria manutenção e continuidade do grupo.

No entanto, a realidade foi se desenhando outros anseios, mostrando-nos que, naquele momento, trabalhar estas questões tinha-se tornado secundário. 
A sensação era a de todo aquele planejamento e conjunto de atividades não pertencia mais a eles, havia ido embora. Os jovens precisavam entender o que estava acontecendo com seu grupo e se, de fato, queriam continuar reunidos.

Senti que era necessário compreender como a ação coletiva estava se dando dentro daquele grupo social. Compreender melhor as relações e comportamentos que existiam.

$\mathrm{Na}$ memória coletiva, aparentemente esquecido, estava um histórico de organização dos grupos, do qual pouco se falava, pouco de ouvia, no entanto muito se sentia.

Torna-se importante mencionar que, após a saída da pesquisadora Branco de campo, várias forma as tentativas de recomeçar, colocar em prática, os planos. Havia material para iniciar a produção do xiitake e do mel, necessitávamos de mão-de-obra, no entanto, o desânimo foi maior.

$\mathrm{Na}$ tentativa de contribuir com a evolução dos trabalhos do grupo, através de uma abertura na disciplina de Projetos de Educação Ambiental da Esalq, grupos de alunos da disciplina auxiliarem dias de campo, através de visitas pontuais. Quando chegavam os visitantes, havia mobilização, mas caso contrário, tudo ficava paralizado. Em pequenas avaliações com o grupo todo, muitas eram as justificativas. Principalmente a sobrevivência, a necessidade de ajudar em casa e na roça, a necessidade de ganhar dinheiro fora, a família, a igreja, a falta de estímulo.

Fatos como o caso da produção de xiitake, foram bastante ilustrtivos da dependência vivida pelos jovens em relação aos pesquisadores.

Em função da limitante tempo e da facilidade e de entrar em com alguns facilitadores que poderiam ajudar a viabilizar os sonhos previstos no JUMAFI, conseguimos algumas doações de materiais para dar início a produção. No caso do xiitake, conseguimos 1 caixa d'água, mangueiras, tora de madeira, o inoculo necessário para a atividade, bem como as telas necessárias para a produção. Ficando a cargo dos jovens colocar a mão na massa". No entanto isso, nuca acontecia, demorando semanas até que eles pudessem se organizar, ir até o local da reunião. Minhas reflexões são na direção da necessidade de se distinguir o tempo de pesquisa do tempo da intervenção, e principalmente da noção de tempo para estes jovens. Outro aspecto relevante é a questão da autonomia e emancipação. Apesar de parecer 
mais fácil resolver e acelerar o processo de doações de todos os materiais necessários pra as atividades, esta atitude transformou- se em um fator negativo, não possibilitando que eles pudessem realmente participar no processo de tomada de decisões sobre o planejamento elaborado por eles próprios.

Este período de tentativas e conflitos grupais durou desde a saídos pesquisadores de campo no final do ano de 1997 até a metade do ano de 1998.

\subsubsection{Caminhos incertos...mudanças de rumo}

É aqui que esta pesquisa, de fato, se definiu. De acordo com os fatos, os resultados vistos, percebidos, nas conversas informais, na visão dos pais e na dificuldade da ação coletiva entre os jovens vivenciada cotidianamente, e principalmente por uma particular inquietação minha em continuar realizando o acompanhamento do grupo de jovens da maneira proposta, novos rumos foram tomados.

Após um tempo de tentativa de ação grupal frustrada, houve uma parada no acompanhamento do grupo por minha parte, dividida com eles. A pesquisa precisa respirar, pensar em como re-direcioná-la

Foi um momento de crise, grande crise. Se ainda, este fosse um projeto de área, seria mais fácil de repensar a situação, teríamos mais tempo e dinheiro. Senti que não convinha continuar insistindo em uma coesão que deveria existir, mas que não se consolidava. As propostas feitas no papel, já tinham perdido o contexto, desde sua criação.

\section{Boas Surpresas}

Após um longo período de 3 meses voltei ao campo, a partir de um telefonema de um dos jovens representante do grupo, grande foi a surpresa. Conversamos um pouco, resgatando a história do JUMAFI. Alguns membros do grupo estavam interessados em dar continuidade ao trabalho. Marcamos um encontro e lá fui eu de volta a Iperó.

A idéia desses integrantes do grupo, era a de recomeçar algumas atividades como a produção de xiitake e de mel, a partir do material já existente e que encontrava-se, naquele momento, abandonado na área do JUMAFI. 
De minha parte, optei mudar a forma de condução das reuniões e conversas do grupo. Assumindo uma postura bastante diferente da anterior. Deixei claro nas primeiras reuniões, que estávamos reiniciando as proposta do JUMAFI e, portanto, precisávamos avaliar o que tinha acontecido para não repetir o mesmo erro, e que para isso, seria necessário avaliar o acontecido e a partir daí reiniciar.

Deste modo, como parte da Pesquisa qualitativa, analisei a história da organização coletiva dentro do assentamento, entre outros fatores para mais adiante poder descrever e analisar aquele processo no grupo de jovens, buscando verificar novas formas de organização social que pudesse contribuir com o trabalho do grupo de jovens. Por algum instantes, tive a impressão que este trauma com o Jumafi, se assemelhou muito a experiência dos pais em relação ao trabalho coletivo desenvolvido no início do acampamento e do qual todos estes jovens fizeram parte. Mais adiante isso pode ser verificado nas entrevistas e nos demais grupos de trabalho no assentamento. A história de formação do local, têm forte influência nas atividades grupais e coletivas propostas.

Deste modo, julgamos essencial compreender o sentido que estes jovens deram a esta experiência vivida, bem como, os comportamento que desenvolveram em relação a si e ao grupo.

Para a realização deste momento de diagnóstico e avaliação, optei por utilizar a técnica do grupo focal.

\subsection{3- O Grupo focal}

Fizemos um trabalho de discussão do JUMAFI através da técnica de Grupo Focal, realizada em um momento do trabalho em que o grande grupo estava a cada dia perdendo suas forças e quase não via mais motivos para continuar existindo.

A técnica denominada Grupo focal é mais utilizada para grupos para se fomentar uma discussão temática, onde a participação de cada pessoa colabora/contribui na compreensão geral sobre o tema, fornecendo a possibilidade de se trabalhar e discutir os fatos que marcaram o processo histórico de organização do grupo e a partir de sua análise mais profunda redefinir seu sentido.

Optei por seguir um formato em que pudéssemos trabalhar com o problema em questão: 'a existência do grupo JUMAFI e sua continuidade', através de 
estímulos diferenciados utilizando técnicas como estímulos visuais, pinturas, dinâmicas de grupo.

A técnica de grupo focal possibilitou a participação de um número maior de participantes, utilizada como uma ferramenta exploratória no trabalho. Além disso, possibilitou também que os indivíduos respondessem as perguntas e atividades propostas na medida em que se sentiam mais motivados, reconhecendo o significado na colaboração dos demais.

Esta atividade foi realizado no dia 26 de Janeiro de 1999, na casa dos irmãos Márcio e Élcio integrantes do grupo JUMAFI, reunindo um total de 13 jovens.

\section{$\underline{\mathrm{O} \text { convite }}$}

Nas semanas anteriores foi realizado um convite pessoal, visita a casa de cada um dos integrantes do grupo grande, expondo a proposta de retomada e discussão dos caminhos do JUMAFI. No entanto alguns não puderam estar presentes principalmente o presidente e o vice-presidente do grupo pois, estavam desacreditados de sua continuidade, além de outros 3 membros, por haverem saído do grupo por motivo de casamento e necessidade de trabalho (sobrevivência).

Entretanto outros jovens que ficaram interessados em saber o que era JUMAFI e que tinham participado de algumas reuniões também estiveram presentes.

Iniciamos o trabalho do grupo focal com as seguintes técnicas:

1) retrospectiva inicial através da dinâmica de grupo

2) Dinâmica das fotografias: foram espalhadas fotos e imagens diferenciadas no chão. Os participantes caminharam por entre as imagens e escolheram uma com que mais se identificaram a fim de responder a perguntar:

- Como me sinto hoje em relação ao JUMAFI ?

3)Conversa aberta sobre a pergunta.

4)Identificação das fortalezas e fraquezas do grupo.

5)Para onde queremos caminhar? Como será o JUMAFI?

As observações foram todas anotadas pela redatora, uma pessoa de fora da comunidade, e logo após foi realizada a sistematização dos dados coletados em campo. As principais resultados foram: 


\section{a) A lógica da ação coletiva no JUMAFI}

No cruzamento de dados e principalmente os dados coletados nas entrevistas iniciais e no grupo focal, tivemos a seguinte situação:

Como me sinto em relação ao JUMAFI hoje?

"Como alguém que não tinha liberdade para agir, e sem ajuda, sem proteção”

"Me sinto como alguém que quer fazer algo mas não pode"

“Como alguém que achou um caminho, mas ninguém foi (medo)”.

“Antes muito bom, mas depois de dispersamos”.

"Pessoal que se desfez, espalhado”.

"Crescendo e depois se dispersou, secou”

"Com a união era bom"

"Preguiça, mas tem força para sobreviver"

"Família desunida, quer uni-la"

"Fraco, sem forças"

"Caminho dificil, estrada dura"

Ao escolherem as fotos (atividade realizada dentro das atividades do Grupo focal), manifestou-se um sentimento forte em relação a tudo aquilo que tinham vivido, e a sensação de estarem 'órfãos' era bastante presente através das falas.

a) Criou-se através do trabalho dos pesquisadores anteriores uma relação afetiva, quase que paternal, onde eles representavam os pais atenciosos e ouvintes do imaginário destes jovens. Trouxe a eles a possibilidade de levá-los para fora, conhecer o mundo lá fora, alguém que acreditasse neles e que enquanto permanecessem ali pelo tempo de suas pesquisas, estariam atentos e disponíveis a dar este tipo de atenção.

"Eu queria mesmo que o Maciel fosse meu pai". André

Tanto através do grupo focal como nas entrevistas formais, conversas informais e na convivência diária os dados nos levavam a resultados muito parecidos, e até certo ponto posições cristalizadas em relação ao processo grupal vivenciado, ou seja, atitudes inconscientes que determinavam atitudes negativas em relação as iniciativas coletivas. 
O estabelecimento da relação afetiva entre pesquisado e pesquisador foi essencial para o desenvolvimento dos trabalhos tanto na fase 1 como na fase 2

A visão de dependência do grupo em relação aos pesquisadores foi um pouco forte, o que pode fortalecer ou fragilizar os processos de autonomia do grupo. No entanto há uma tendência a esperar que o pesquisador traga as alternativas prontas, as sugestões e as idéias. Trabalhar esta relação, foi um dos principais aspectos do trabalho durante a pesquisa, pois uma vez a relação estabelecida, cria-se uma grande demanda por resolução de problemas através do pesquisador e não do grupo que está vivendo o problema. Nesta etapa do trabalho, dois dos grupos praticamente desistiram de fazer parte do grupo, e somente a media em que viram que os demais grupos estavam conseguindo produzir e trabalho é que veio o ânimo para recomeçar.

\section{$\underline{\text { Dificuldades }}$}

Os aspectos que mais os incomodaram durante o processo de montagem do grupo foram:

-a falta de transporte, a distância do local aonde o grupo tinha que se reunir.

"Eu tava buscando um futuro, o problema era a área 1 se longe da área 2" Élcio

"Eu as vezes, tinha que ir de a pé, de cavalo ou carroça, anda 1 hora prá chegar na reunião”. Márcio

"Quando a gente tinha o Maciel que buscava a gente era mais fácil, depois sem eles ficô difícil” Ivan

-O excesso de projetos e a dificuldade que sentiam de se reunir sozinhos

"Antes quando tinha a Teresa a gente se reunia, depois sem eles ficô tudo mais dificil, a gente se reuní sozinho não tinha força”. Ariane

"Quando a Teresa foi embora, ela falô que a gente tinha que se reuní sozinho, mais era difícil faze as pessoa $i$, todo mundo desanimô”. Elisete

"Era muito projeto, a gente sonhô muito alto". Uanderson

-Falta de união e a disputa que se instituiu entre os participantes da área 1 e da área 2.

“Depois da eleição, aí ficava aquela briga, prá ver quem tava de que lado". Ariane 
“Prô pessoal da área 1 era mais fáci, eles tava perto da Reserva...” Marcos

A eleição que distribuiu cargos e iniciou-se um processo de separação entre os integrantes.

“Essa coisa de eleger presidente desanimou a gente..." Uanderson

-O fato de perderem as doações.

"Depois do Maciel e a Teresa te conseguido tudo aquilo prá gente e tudo se perdê, aí desanimô". Ivan

-O tamanho do grupo

-O excesso de reuniões e pouca prática

"Alguns queriam individual, outros queriam junto, no grupo grande um deixa para o outro, no grupo pequeno cada um faz falta" Élcio

"O trabalho tem que ser dividido e caso, um com sua função, e se não faz é cortado ou punido”. Uanderson

“Eu queria era por a mão na massa, esse negócio de reunião num é comigo”. Márcio

"No começo eu começei a participá, mas ficou essa história de muita reunião, eu achei melhó num i mais". Marcos

De uma maneira geral após esta experiência coletiva maior, os jovens expressavam através de suas falas, a opção por grupos de trabalhos menores, onde tivessem menos reuniões, ou seja, que a experiência do grupo estivesse mais próxima da realidade em que eles haviam vivido até o momento.

“Eu tenho medo de arriscar de novo e perder tempo”. Elisete

"Eu queria mexê com as abeia mas só eu com minhas irmã”. Elisete

Estas falas indicavam caminhos, fazendo uma retrospectiva na história de construção do grupo e uma reflexão sobre as ações do presente e as alternativas para o futuro deste mesmo grupo.

Podemos observar que a lógica da ação coletiva que se estabelece é aquela em que há uma tentativa por parte da equipe de agentes externos e dos jovens de trabalhar coletivamente em um grupo maior, heterogêneo, com outros jovens diferentes deles, de outras religiões, crenças onde não necessariamente existia relação de convivência e afetividade anterior. 


\section{a) Frustação em relação ao insucesso do JUMAFI}

"o grupo foi um mimo, igual quando uma criança pequena pede colo". Uanderson "precisava ter pensado antes(...) eu avisei". Marcos

"eu gostava de ir lá, mas depois eu tinha que ficar coma minha mãe...então não deu mais (...) gostei mais da viagem prá Itatinga". Ivanildo

Os jovens Marcos e Ivanildo começaram a fazer parte do grupo JUMAFI e depois de algumas reuniões não se sentiram mais estimulados a fazer parte do grupo.

\section{b) sentimento de nostalgia por um momento que lhes trouxe muitas alegrias}

"a gente gostava de ir prá Itatinga ${ }^{26}$, lugar mais lindo, podia o Jumafi ser daquele jeito" Cristiane

"até que o JUMAFI era bom prá mim, mas agora num dá mais (...) tenho que trabalhá...agora faço sanduíche na lanchonete lá do trailer". Eduardo

\section{c) o grupo heterogêneo, criou-se um separatismo entre jovens que moravam}

\section{na áreas 1 e 2 do assentamento.}

"estragó quando o pessoal da área 2 ficava brigando com o pessoal da área 1 e ninguém fazia mais nada" Cristiane

"eu morava na área 2 e ía a pé mesmo prá lá, tinha veis de chega lá e num aparece ninguém" Ivan

\section{d) As meninas do grupo sentiam deixadas de lado nas decisões.}

"quando vocês que coordena não vem prás reunião, os menino nem pergunta nada prá gente, num dá nem vontade de participá". Elisete

"num adianta reuní, ninguém vem, tem mesmo é que sé um grupo só a gente".

Elisete

"eu acho que o pessoal ía prá reunião como quem vai prá sair de casa no final de semana, mas na hora de por a mão na massa nada". Silvana

\footnotetext{
${ }^{26} \mathrm{O}$ JUMAFI teve dois encontros que foram realizados fora do assentamento, no Horto Florestal de Itatinga-SP.
} 
"eu me decepcionei com o JUMAFI, aquela história de presidente estragou tudo". Ivan

Outros aspectos foram observados e discutidos nas conversas e reuniões com os jovens, nos passeios e entrevistas, era sobre as alternativas de produtividade agrícola na terra.

Muitos apontavam que depois de terem saído e visto coisas novas achavam que poderia ficar e cuidar da natureza e produzir alguma coisa que seja mias fácil e rápido, outros se sentiam muito desanimados em continuar praticamente sem forças, preferiam tentar um emprego lá fora, onde tinham garantia de um salário fixo todo mês.

No entanto, algumas barreiras como as histórias anteriores marcadas por conflitos nas relações internas de trabalho coletivo vivida pelos pais destes jovens, tiveram grande influência nas reações e respostas na experiência que estavam vivendo, outros aspectos como religião, gênero, idade e a mistura de tribos também se transformaram em barreiras quando da prática do trabalho coletivo.

Este histórico organizacional inconsciente podia ser identificado repetidas vezes em diferentes momentos e principalmente no enfrentamento de conflitos vivenciados por eles. Estes elementos funcionavam como 'muros mentais' intransponíveis que não estavam aparentemente presentes, mas que se manifestavam nas ações e atividades cotidianas grupais.

\section{- Outras atividades desenvolvidas no grupo}

\section{Pais buscam alternativas de geração de renda para os jovens}

Em momento mais avançado da pesquisa, houve um movimento dos pais do grupo de apicultura da área 2, juntamente com o apoio do ITESP, para trazer a instalação de uma escola técnica-agrícola para o assentamento, a proposta da Escola Famíliaagrícola. Neste momento tivemos participação a convite do Conselho de representantes do assentamento e de um representante de uma escola técnica nas primeiras reuniões do grupo de pais.

A partir daí, os técnicos do ITESP, colaboravam em suas participações nas reuniões do Conselho, com a idéia da necessidade de se garantir no planejamento das 
atividades do assentamento, alternativas para garantir a permanência do jovem no local.

"Ter uma escola aqui dentro pode facilitar muito prá vocês, capacitar estes jovens". Magoo

Percebemos um movimento diferente do Conselho em relação aos jovens, inclusive como garantir de preservar o patrimônio adquirido, a terra melhorando as condições de vida na comunidade.

Em entrevista, visitas e estadas com os pais dos jovens participantes do JUMAFI, tivemos um quadro muito interessante, houve bastante interesse em se manisfestar, tinham muita coisa a dizer. Foram feitas as entrevistas com o Pastor Cláudio e D. Jô (pais da Luciana, Marcos, Milena), Pastor Antônio e D. Magnólia (Elisete, Gisele e Sandra), D. Arina e Sr. Oswaldo (lideranças locais), Sr. Ligeirinho e D.Otávia (pais do Ivan), Sra. Susi (mãe da Tati), D. Mariquinha (mãe do Márcio e Negão), Boaventura (liderança local), Carlão (liderança local), Sérgião(liderança local), D. Celina e Edilson (pais do Márcio, Élcio e Negão).

Como no momento anterior da formação dos grupo JUMAFI não houve uma conversa com os pais dos jovens, estava latente o desejo de se manisfestar, falar sobre o que achavam do grupo e dos seus objetivos, sua visão sobre a participação dos filhos no assentamento e das alternativas existentes.

\subsubsection{Considerações sobre tamanho e formação de grupos}

A mudança do grupo grande para o pequeno trouxe muitas mudanças e maior desenvolvimento para o trabalho no interior dos grupos. No entanto outros grupos que se propuseram a trabalhar, se sentiram desestimulados a levar adiante seu projeto.

Acredito serem diferenciados os motivos que levaram alguns integrantes a deixar de participar, principalmente os demais integrantes do JUMAFI que não quiseram se aventurar na experiência de trabalhar em grupos menores como estes quatro.

Para Olson (1999, p.20) economista neoclássico defensor da teoria que explica o comportamento humano através da teoria da escolha racional " $a$ 
dificuldade em se analisar a relação entre o tamanho do grupo e o comportamento do individuo no grupo se deve ao fato de que cada individuo em um determinado grupo pode conferir um valor diferente ao beneficio público almejado por este grupo".

O autor acredita que em qualquer grupo em que a participação for voluntária, "o membro ou membros, cuja parte do custo marginal exceder sua parte das vantagens adicionais parará de contribuir para a consecução do benefício coletivo antes que o ponto ótimo de obtenção do benefício coletivo para o grupo como um todo tenha sido atingido".

Para o grupo JUMAFI, no tempo 1 da pesquisa pudemos ver que em determinado momento alguns membros tentavam impulsionar o grupo, quando outros (por diferentes motivos) apenas esperavam desfrutar dos benefícios coletivos alcançados. $\mathrm{O}$ autor acredita que os pequenos grupos podem satisfazer muito mais aos propósitos comuns de seus membros do que no grande grupo.

Defende a sua tese dizendo que quando o número de participantes é grande, o participante típico tem consciência que seus esforços individuais provavelmente não influenciarão muito no resultado final e de que ele será afetado da mesma maneira pela decisão da reunião.

Olson (op.cit, p.65) afirma que por este motivo as organizações recorrem com tanta freqüência ao pequeno grupo e dá exemplos "comitês, subcomitês e pequenos grupos de liderança são criados- e uma vez criados, tendem a desempenhar um papel crucial".

O professor James (1951) citado por Olson (op.cit, p.66) descobriu que em uma grande variedade de instituições públicas e privadas nacionais e locais norte americanas, os grupos e subgrupos 'ativos' tendem a ser muito menores do que os grupos e subgrupos que não agem. Em um dos casos estudados, o tamanho médio do grupo ativo era de 6,5 membros, ao passo que o tamanho médio dos grupos não ativos era de 14 membros.. E conclui afirmando que "os comitês devem ser pequenos quando se espera ação, e relativamente grandes quando se buscam pontos de vista, reações, etc.". 
Outra experiência citada por Olson através do trabalho de Hare (1952) em grupos de 5-6 e de 12 garotos, constatou que em geral o desempenho do de $5 \mathrm{em}$ geral era superior.

Simmel (1950) citado por Olson (1999, p.68) menciona que "os grupos pequenos e centripetamente organizados costumam reunir e empregar todas as suas energias, ao passo que nos grupos grandes essas energias permanecem com muito mais freqüencia em estado potencial".

O autor levanta também um aspecto importante que é a questão do consenso grupal, supondo que um dos problemas a seram enfrentados por organizações internas de grupos pequenos geralmente esta ligada ao grau de consenso da decisões. "se houver muitos desacordos sérios, não haverá esforço coordenado e voluntário, mas se houver um alto grau de concordância a respeito do que se quer e da forma de obtê-lo é quase certo que haverá ação grupal eficiente".

Neste sentido coloca que é preciso distinguir ente os obstáculos em relação a ação grupal referentes a grau de consenso ou aqueles referentes a falta de incentivos individuais para a realização da tarefa coletiva.

Maffesoli (1997) acredita que estamos vivendo hoje um momento de transfiguração do político, onde os papéis sociais estão se redefinindo e uma forte tendência ao tribalismo está emergindo.

Segundo o autor, vivemos em uma época contemporânea onde as pessoas não estão mais voltadas a projetos de futuro como pregava a modernidade, e sim voltados a valorizar o presente. Acredita que esta tendência estaria fortalecendo os pequenos poderes, as estruturas locais e os pequenos grupos.

Tassara (1997) interpretando Maffesoli, ressalta que organizados em pequenos grupos de pressão, em verdadeiras tribos, os homens terão que encontrar novas formas de convivência e de respeito mútuo.

Portanto outras estratégias de ação grupal estariam sendo enfatizadas, outras formas de prazer do estar junto como a afetividade e o desenvolvimento de laços afetivos capazes de compreender e contribuir para o desempenho do trabalho do grupo.

Olson (op.cit) apesar de creditar grande parte das explicações de sua teoria através da lógica racional instrumental acredita que não apenas um incentivo 
econômico seria capaz de alavancar forças para a ação de um grupo mas também desejos de prestígio, respeito, amizade entre outros objetivos de fundo social e psicológico.

Encontramos nesta teoria algumas explicações para fenômenos grupais que ocorrem, porém é importante salientar que as ações e fenômenos grupais acontecem pela influência de uma série de outros fatores além da decisão individual racional em relação a uma atitude grupal.

Reis (1982) citado por Porto (1997, p.43) menciona que os trabalhos orientados sob esta lógica são marcados por um 'individualismo metodológico' caracterizando uma postura anti-sociológica, caracterizando uma visão de sociedade "onde não há instituições ou história"

Uma das principais críticas do autor direcionadas a teoria da escolha racional é a de considerar o indivíduo como ator-racional que maximiza os meios de acordo com os fins e a relação custo/benefício, sendo que fica muito difícil determinar o tipo deste ator-racional e aplicá-los aos atores-reais.

Concordamos que uma única forma fechada de análise teórica é insufuciente para analisar fenômenos sociais, portanto existem fatores da lógica racional a serem considerados por uma análise global das ações coletivas e outros que não podem ser considerados apenas por esta teoria.

Porto (1997, p.45) sugere outras formas de análise para a ação social e o comportamento político principalmente aquela baseada em valores, para tanto se remete a Weber (1991, p.15) citando "age de maneira racional referente a valores quem, sem considerar, sem considerar as conseqüencias previsiveis, age a serviço de sua convicção sobre o que parecem ordenar-lhe o dever, a dignidade, as diretivas religiosas, ou a importância de uma causa de qualquer natureza".

De fato, Porto (1997, p.46) levanta a questão que os indivíduos podem agir racionalmente a uma atitude grupal em relação aos custos e benefícios que ele irá ganhar, mas que também, poderá optar por agir de forma racional com relação a seus valores e aos do grupo. E afirma que "qualquer teoria sobre a ação social deve necessariamente trabalhar com um conceito mais amplo de racionalidade, não se restringindo a análise instrumental, incorporando a racionalidade com relação a valores como um elemento fundamental da análise política". 
Porto (1997, p.47) sugere ainda que seja levado em consideração também uma forma de análise do papel das emoções "ultrapassando tanto a negligência quanto o preconceito que tem predominado tanto nas ciências sociais como na ciência política". Enfatiza que a importância desta análise existe porque as emoções estabilizam a vida social, interferem com o nosso processo de pensamento, tornandoos menos racionais do que seriam de outra forma.

Weber (1971, p.4-5) citado por Porto (1997, p.48) reconhece a possibilidade de que as emoções sejam um fator determinante da ação social.

"impulsos afetivos (medo, cólera, ambição, inveja, ciúme, amor, entusiasmo, orgulho, sede de vingança, piedade, dedicação, apetências de toda espécie) e as reações irracionais (do ponto de vista racional, orientada por um fim) que deles resultam podem ser revividos por nós emocionalmente e com tanto mais evidência quanto mais suscetiveis a esses mesmos afetos..."

Outro aspecto citado por Porto seria o papel e a influência da intuição na tomada de decisão em ações coletivas grupais, apenas ressaltamos este aspecto por não ser objeto deste estudo, no entanto empiricamente, percebemos que existe também esta influência em campo, não podendo neste estudo, no entanto, ser mensurada e discutida com mais ênfase.

Trouxemos estas reflexões acerca das influências que determinam a ação grupal para deixar claro, que, em uma análise das atitudes dos indivíduos em um grupo, podem ser diversas as reações e complementares as formas de análise. Por um lado torna a análise mais complicada de ser feita, por outro é uma tentativa de compreender o fenômeno social como um todo, em sua complexidade.

Deste modo, optamos por não tirar conclusões fechadas e acabadas através da análise deste estudo, e sim, indicadores para a análise da ação coletiva nos pequenos grupos derivados do JUMAFI.

Morin (1990, p.9) pondera "certamente, a ambição do pensamento complexo $^{27}$ é dar conta das articulações entre domínios disciplinares, que são quebrados pelo pensamento disjuntivo (que é um dos aspectos principais deste

$27 "$ "Complexus = o que é tecido em conjunto de constituintes inseparavelmente associados(...) tecido de acontecimentos, ações, interações, retroações, determinações, acasos, que constituem nosso mundo fenomenal" (MORIN,1990, p.20-21). 
pensamento simplificador) Este isola o que ele separa e oculta tudo o que liga, interage, interfere".

\section{-Autonomia}

Um dos principais valores norteadores da pesquisa em questão, é da prática emancipatória, o de contribuir para transformação dos indivíduos em sujeito, portanto, a noção de autonomia, é um princípio fundamental.

No acompanhamento em campo dos grupos, notávamos que havia por parte dos jovens, a necessidade de um líder externo a eles, quase que um 'chefe' que pudesse determinar as ordens e então eles pudessem cumprir. De alguma forma, seria uma álibi, caso não dê certo, dividimos a culpa.

De modo geral, o processo de autonomia, de se tornarem sujeitos de suas próprias ações era uma tarefa extremamente difícil de realizar.

No caso do grupo 3 por exemplo, o desenvolvimento do trabalho foi bastante lento. Sentíamos que as integrantes do grupo (eram só mulheres) tinham força mas ao mesmo tempo, se sentiam inibidas de atuar. Estavam sempre esperando uma ação de fora, ou a ajuda de seu pai.

Para compreender melhor este fenômeno, relacionamos esta reação a outras igualmente parecidas de outros agricultores e até mesmo de seus pais.

Para Campos (1996, p.171) as representações sociais explicam em parte este fenômeno, pois dá ênfase ao estudo do aspecto social, isto é, interindividual da representação.

Moscovici (1961) citado por Campos (1996) descreve as representações sociais como representações coletivas, "enquanto construções simbólicas historicamente determinadas, socialmente compartilhadas e comunicadas através de redes institucionais específicas, que ao mesmo tempo modelam as ações dos grupos no interior da formação social considerada, e são por elas moldadas".

Portanto o que determina o comportamento do indivíduo não é apenas sua própria representação, mas a rede de relações sociais que eles compartilham com os demais membros da comunidade ${ }^{28}$, sendo portanto alvo de constantes transformações.

\footnotetext{
${ }^{28}$ Sawaia (1994, p.50) cita Nisbet(1974, p.48) para representar todas as idéias fundamentais de comunidade "comunidade abrange todas as formas de relacionamento caracterizado por um grau elevado de intimidade pessoal, profundeza emocional, engajamento moral(...)e continuado no tempo.
} 
Porto (1996, p.172) ressalta dois aspectos fundamentais na compreensão das representações sociais e na análise das ações individuais e grupais "em primeiro lugar a idéia de que as representações que os sujeitos constróem entre si são frutos de histórias já construídas, e como tal são transmitidas. Em segundo lugar, a lembrança oportunidade que as práticas presentes vão progressivamente contribuir para introduzir novos elementos nas representações, e, em última instância para transformá-las".

Complementa dizendo que esta dialética é que permite avançar na compreensão da análise das ações grupais, fazendo movimentar as categorias já cristalizadas coletivamente trazendo o movimento de renovação que nasce nas práticas cotidianas.

O mesmo tipo de comportamento pôde ser observado através da reação de muitos assentados em relação ao trabalho coletivo, devido a experiência bastante negativa que viveram do trabalho coletivo quando da formação do assentamento, muitas pessoas cristalizaram esta forma de organização coletiva como estritamente ruim, o que imobiliza novas tentativas, endurecendo e cristalizando mais as relações, por exemplo, com o MST, e por outro lado, não resolve o problema.

A representação social deste 'trauma' coletivo, nos filhos é em alguns casos evidente.

"resolvi sair, porque trabalho de grupo num dá certo, um rouba o outro, no grupo do meu pai foi assim..." Ronaldo

Este aspecto é aqui avaliado como tremendamente influente nas práticas coletivas dentro do assentamento, que ressalta o aspecto da importância da confiança do grupo em seus membros.

Outro fator muito importante de ser analisado é o fato de muitos destes assentados terem sido outrora, trabalhadores assalariados de fazendas, metalúrgicas, caseiros de sítios, empregadas domésticas, enfim, empregados, assumindo uma posição de servidão durante quase toda a vida.

Ela encontra seu fundamento no homem visto em sua totalidade e não neste ou naquele papel que possa desempenhar na ordem social(...) a comunidade é a fusão do sentimento e do pensamento, da tradição e da ligação intencional, da participação e da volição". 
Consideramos fortemente o fato de estarem lutando por um pedaço de terra, ser um fato glorioso, no entanto este hábito servil de outros tempos, em alguns casos, está fortemente arraigado e acentuado por diferentes motivos também.

A representação desta condição servil, em que o indivíduo não se sente com direito a nada, proibido de ter prazer, lazer, diversão, proibido de se expressar, cria consequentemente uma barreira contra a autonomia. Acredito que a conquista e percepção desta condição faz parte de um processo de construção da cidadania.

Busquei compreender este fenômeno através da teoria do discurso da servidão voluntária de La Boétie.

Podemos ver em Unger reflexões sobre esta condição aparentemente inerte e de servidão na qual se encontram indivíduos e grupos sociais.

Em "O discurso da servidão voluntária" de Etienne de La Boétie (1982) citado por Unger (1991), Maffesoli (1997), Santos (1995) há uma contribuição à compreensão deste fenômeno social que se manifesta de diferentes maneiras e que nas palavras de Maffesoli ao analisar o papel do político "engendra uma submissão fatalista, a passividade da massa que, conforme os regimes, procuraremos ou temereremos. Na base desta passividade, está o fato de que se cede a outro o cuidado de se assegurar a tranqüilidade do conjunto(...) curiosa pulsão que força à submissão, a 'entregar-se' ao outro. Aceitar chefes e conforme a necessidade procurá-los. Em realidade muitas são as expressões da submissão(...) Essa delegação tomará formas bastante diferentes, da democracia ativa à tirania totalitária, passando pela aceitação tácita contida na abstenção” (p.38).

Como complementa Unger (1991, p.40) a servidão voluntária desfaz os hábitos com os quais nos acostumamos a pensar o político. A corrente de tirania atravessa a sociedade de ponta a ponta, pois a 'vontade de servir' encobre o desejo de participação na tirania, o desejo de ser também tirano.

Esta tendência aparentemente natural existe de fato, podendo ser vista, através de iniciativas diferenciadas, geradores de movimentos sociais e formas de organização alternativas, determinando nichos de segurança, onde as pessoas podem se identificar.

Maturana (1997, p.185) afirma esta condição dizendo que "é através da razão que justificamos a tirania, a destruição a natureza, ou o abuso sobre outros seres 
humanos (...) justificamos a tirania afirmando que outros seres humanos deveriam obedecer caprichos sobre a verdade ou realidade, porque possuímos um acesso privilegiado a ela".

\subsubsection{Os grupos pequenos: acompanhamento e reuniões}

Após as conversas e as ponderações dos próprios jovens, decidimos que não poderíamos continuar acompanhando o grupo da mesma forma que acontecia no tempo1 pois a situação era diferente e havia a necessidade de restabelecer as regras do jogo para que o grupo continuasse existindo.

A primeira proposta que surgiu nas reuniões com os jovens era a de que o trabalho somente renderia se as pessoas do grupo que tivessem maior afinidade por determinado projeto se juntassem para realizá-lo desvinculado da idéia e da necessidade de 'estarmos todos juntos para todas as atividades', além disso outro aspecto relevante desta avaliação do trabalho grupal foi a questão da convivêncialidade entre eles, o aspecto do trabalho em grupo e as relações interpessoais.

"eu e o Alemão não era amigo nem na escola, a gente conversava só nas reunião do JUMAFI". Márcio

Esta fala emergiu em uma das entrevistas, quando este integrante do grupo se referia a falta de amizade, afinidade entre ele e o Uanderson (Alemão) e que tiveram problemas quando tendo que trabalhar juntos na mesma atividade.

Optamos por formar estes pequenos grupos, deixando claro o nosso papel, de apoio ao desenvolvimento do grupo, ou seja, deveria haver uma independência nas atividades de cada grupo, como reuniões entre eles, a tomada de decisões e sobre as divisões de tarefas e a forma de suprimento das necessidades que foram surgindo.

Em princípio foram formados 4 grupos:

Grupo 1: Márcio, Élcio, Kleber, Negão, Ricardo e Ronaldo

Grupo 2: Marcos, Márcio, Eliseu, Uanderson

Grupo 3: Elisete, Sandra, D. Magnólia, Gisele, André

Grupo 4: Silvana, Ivan, Alemão 
No acompanhamento de cada grupo entramos na fase da redefinição dos objetivos de cada pequeno grupo, utilizamos para isso a técnica denominada oficina do futuro $^{29}$ técnica de resolução de problemas.

Os grupos 1, 2 e 3 tinham em mente trabalhar com apicultura, devido ao estímulo que tiveram através de visitas a áreas apícolas realizadas no tempo 1 do trabalho.

\section{- Acompanhamento dos 4 pequenos grupos derivados do grande grupo JUMAFI}

Durante esta etapa, realizamos um planejamento participativo das atividades de cada grupo e o acompanhando as atividades desenvolvidas, não interferindo diretamente em suas decisões e na dinâmica de relacionamento e trabalho encontrada pelo grupo.

Tínhamos a preocupação de deixar claro que estaríamos em campo por pouco mais de 12 meses, e que através da proposta de grupos menores estariam experimentando uma nova forma de organização.

Ainda nesta fase, a partir do planejamento realizado, busquei conjuntamente opções de capacitações diferenciadas, além de contatos diretos com interlocutores das técnicas de trabalho escolhidas por eles. Durante este período os 4 grupos de jovens optaram por: criação de abelhas, cultivo de cogumelo xiitake, produção de flores e plantas ornamentais.

Nesta fase deu-se o acompanhamento dos 4 grupos.

A principal discussão que se instalou em todos os grupos foi a de como seria a escolha dos integrantes de cada grupo, que aspectos deveriam levar em consideração, e como optar pelos integrantes. Nas entrevistas e conversas podia-se notar através das falas que havia uma tendência a chamar as pessoas que estivessem mais próximas fisicamente e também pela convivência cotidiana "Nóis já sabe que nóis qué trabaiá junto, eu, meus irmão, o Ricardo e o Klebinho (...) nóis pensa igual, é mais fácil". Márcio

Os integrantes dos grupos tinham entre 13 e 23 anos. Segundo as nações unidas a juventude compreende o período entre 15 e 24 anos embora a CEPAL, 1996, p.251 citado por Abramovay (1998, p.37) este período avance até os 29 anos quando se trata de jovens rurais.

\footnotetext{
${ }^{29}$ Técnica de planejamento participativo.
} 
Nos resultados da oficina de futuro, o grupo 1 se reorganizou, levantando os problemas existentes e que deveriam ser solucionados para que o trabalho fosse adiante, definindo um plano de ações:

-entrar em contato com a CAPIDE (ONG de Sorocaba que desenvolvia um trabalho de apoio a grupos de jovens voltado a apicultura)

-desenvolver as áreas de trabalho apícola

-verificar a necessidade de plantio de mudas para maior atração apícola -marcar reuniões periódicas do grupo

-fazer cronograma de atividades e divisão de tarefas

Já o grupo 2 resultou através da oficina de futuro que eles não tinham problemas a resolver, era só "tocar as abéia, as colméia que tem", definiram que como já estavam cultivando 4 caixas de abelha a algum tempo esta já deveria Ter mel, portanto a preocupação era a de colher, comercializar e dividir o dinheiro entre eles.

O planejamento do grupo 3 foi mais demorado pois tratava-se de um grupo familiar, onde os pais, quiseram entender um pouco mais das opções das filhas mulheres, quererem trabalhar com abelhas, já que há de certa maneira um certo preconceito, por este ser um trabalho pesado para mulheres segundo alguns meninos. Além disso este grupo também decidiu trabalhar com o cultivo de plantas ornamentais, realizamos cronograma de atividades e uma das principais demandas era a capacitação para a produção de plantas. No entanto o grupo resolveu preparar o terreno e a área a ser utilizada para o cultivo das plantas além de buscar local adequado para instalação da primeira caixa de abelhas.

O grupo 4 optou por trabalhar com produção de cogumelos comestíveis, logo no início teve problemas para se reunir apesar da séria determinação de dar início as atividades com a produção de cogumelo xiitake, pois tratava-se de um casal de jovens que quando entraram para o JUMAFI, eram namorados, após alguns meses, a jovem ficou grávida e tiveram que se 'juntar' morar com os pais dele, e logo em seguida tiveram um outro filho, portanto, começou a haver uma forte pressão dos pais do Ivan, para que ele não 'perdesse tempo com reunião' e ajudasse o pai na produção interna do sítio e nas despesas da casa. Isso veio a desestimular o 
envolvimento do próprio grupo, uma vez que o Ivan era uma espécie de líder deste grupo, os demais integrantes se sentiram impossibilitados de continuar.

Desta realidade emerge uma situação bastante representativa do contexto onde se encontram os jovens no assentamento, há pouco ou quase nenhuma oportunidade (oferecida pelos pais) para que desenvolvam atividades não-agrícolas diferenciadas das tradicionais como o plantio de milho e feijão, mandioca, algumas outras culturas e criação de gado.

Abramovay (1998, p.92) salienta como um dos passos de maior importância neste sentido seria a valorização de atividades não-agrícolas, tanto pelos pais destes jovens, como pelas instituições interventoras (governamentais e não-governamentais) e complementa dizendo que "seja na agricultura ou em atividades rurais nãoagrícolas, a iniciativa dos jovens vivendo hoje no interior da agricultura familiar encontra-se fortemente inibida, não só por razões estritamente econômicas, mas também pela natureza das relações entre as gerações e entre os gêneros".

Afirma ser fundamental o estímulos à discussão dos processos sucessórios no interior das famílias por parte das organizações representativas e vai mais adiante refletindo sobre a falta de atitudes políticas que estimulem novas práticas agrícolas "é fundamental que os jovens sejam contemplados com programas de capacitação e linhas de crédito que propiciem a base material de sua afirmação como futuro agricultor".

No acompanhamento em campo destes grupos, tiramos uma agenda de prioridades, principalmente as que traziam cursos de capacitação em diferentes áreas para que os jovens pudessem ir se independizando em relação a atividade que pretendiam desenvolver.

O contato e parceria com a ONG CAPIDE possibilitou a realização de cursos de apicultura no assentamento além do acompanhamento dos apiários por um técnico especializado através de visitas quinzenais.

Foram também realizados dois cursos de jardinagem e produção de mudas através da parceria com um técnico agrícola do Parque Ecológico Monsenhor Emílio José Salim de Campinas, para os grupos e pais interessados, onde tivemos uma grande participação e grande mobilização interna. 
Os grupos 1 e 2 de apicultura participaram do Encontro de Agricultura Alternativa na ESALQ/USP em Piracicaba através de parceira com a organização do evento, possibilitando a realização de oficinas de plantas medicinais, apicultura aplicada, cogumelos comestíveis e minhocultura. Neste momento da pesquisa, pudemos perceber que o fato dos jovens estarem em contato direto com os professores, grupos de trabalho específicos das áreas técnicas de interesse deles, facilitou o envolvimento e compreensão das dificuldades de trabalho nas atividades e por outro lado desmistificou a necessidade de sempre ter um interlocutor externo para suprir as necessidades e dificuldades encontradas em campo.

Através destes cursos, os jovens fizeram contatos diretos com os profissionais, chegando a viabilizar cursos de interesse comunitário para o assentamento, como foi o caso das plantas medicinais e de bolsas de estudo em apicultura aplicada na ABRACAM ${ }^{30}$.

Pudemos verificar que a saída para ver iniciativas novas de outros assentamentos, outros grupos de agricultores, foi bastante motivante. Porém surgia aqui, a necessidade de rediscutir o trabalho coletivo dentro do assentamento.

Durante todo o trabalho de formação do grupo de jovens, os pais não viram muita importância nos grupos, porém quando estes grupos iniciaram a comercialização de seus produtos e sub-produtos, os pais demonstravam grande interesse. A partir do momento que a produção foi positiva e começaram a comercialização do mel e do própolis, houve um reconhecimento do trabalho, passando a ouvir mais as alternativas propostas trazidas pelos seus filhos.

Neste momento do trabalho, havia uma grande interação com os pais dos jovens, através das visitas e da estadia da pesquisadora, que optou por revezar e permanecer em diferentes casas durante o trabalho de coleta de dados em campo. Esta interação gerou uma série de demandas e participações esporádicas em grupos diversos dentro do assentamento, como o grupo de mulheres e o mutirão para a construção do centro comunitário, convivência no trabalho cotidiano do ITESP junto aos agricultores e como convidada nas reuniões do Conselho Interno do assentamento.

\footnotetext{
${ }^{30}$ Associação Brasileira de Apicultores com sede em São Lourenço da Serra-SP foram obtidas bolsas de estudo para cursos completos de apicultura.
} 
Mencionamos rapidamente a necessidade surgida entre os pais e jovens do assentamento de rediscutir as questões coletivas, portanto a partir das conversas informais nas reuniões dos jovens e outros encontros informais, surgiu a demanda pela visita ao assentamento de Itapeva, o qual com apoio do MST, vem desenvolvendo a alguns anos trabalhos coletivos como grupos diferenciados (de mulheres e de jovens) para a construção de uma proposta de ação coletiva. Através da parceira com o Sindicato dos Químicos de Sorocaba conseguimos transporte e combustível para viabilizar a viagem, onde participaram o grupo de mulheres, mães de jovens e integrantes dos grupos de jovens. Esta viagem foi bastante positiva, pois gerou uma motivação interna, além da possibilidade de contatos maiores com assentamentos vizinhos que enfrentavam situações semelhantes.

Este envolvimento trouxe aspectos positivos para a coordenação do assentamento, a necessidade de desenvolver algum tipo de programa direcionado aos jovens, e até mesmo apoio às atividades desenvolvidas por eles. Foi a partir desta iniciativa e da disposição de colaboração apresentada pela CAPIDE que formou-se um grupo de pais dos jovens interessados em montar uma pequena marcenaria para a fabricação de caixotarias e principalmente as caixas de abelha. O grupo se estruturou com voluntários para dar as aulas de marcenaria e para a construção do galpão para os trabalhos, um dos pais cedeu um pedaço de sua propriedade para que fossem feitas as construções do galpão e a CAPIDE cederia as máquinas necessárias para o trabalho. Na época da nossa saída de campo, apesar de toda esta mobilização, as negociações entre a CAPIDE e o assentamento estavam em andamento e apenas a construção do galpão havia sido iniciada.

O Conselho de representantes do assentamento optou por refletir mais sobre o assunto de um programa voltado aos jovens do assentamento afim de minimizar o grande número de jovens que estava deixando o assentamento por falta de oportunidades e falta de afinidade com o trabalho na terra. Podemos ver nas falas ocorridas em uma das reuniões do Conselho.

"Prá mim, eu quero vê meu filho aqui com a gente, produzindo, construindo a familia dele, prá isso, pessoal, nós tem que pensa em fazê alguma coisa prá esses menino". Sérgião, líder do conselho 
"Talvez trazê prá cá uma escola, como já teve no começo do acampamento...". Sérgião

"quanto jovem já foi embora, porque num queria trabaiá na enxada...tem muito que num qué isso prá eles, vai pra cidade trabaiá...". José Darcy

Estas percepções estavam sendo desenvolvidas, porém o papel deles pais enquanto agentes estimuladores ou não, não estava claramente perceptível para alguns.

É importante colocar que, todo este processo de envolvimento e desenvolvimento foi crescente, mas também enfrentado muitas dificuldades por diferentes motivos.

A seguir listaremos algumas dificuldades diagnosticadas através das análises no cotidiano das atividades e no interior dos grupos de trabalho.

\section{- Questão de gênero}

Percebemos aqui dificuldades ligadas a questão de gênero e da servidão, ou seja, estavam habituadas a obedecer as ordem do pai, e a mãe sempre teve um papel submisso frente as iniciativas de geração de renda para a família.

"o pai ficô de fazê os canteiro...mas num teve tempo". Elisete

"eu esperei os menino para ir junto escolhê o lugar da abelha...eles num viero, eles acha que muié num é prá cria abelha" Elisete

Abramovay (op. cit) em suas pesquisas sobre o processo sucessório de jovens agricultores no sul do país deixa claro que a masculinização do meio rural não pode ser encarada como processo natural do processo de desenvolvimento. A intensidade do êxodo rural juvenil feminino é a expressão da maneira como o poder se distribui no interior da família". O autor salienta que, as responsabilidades, o planejamento e a participação, até mesmo a apresentação social na qualidade de agricultora é praticamente vedada às jovens.

Segundo Panzutti (1996, p.9) citado por Abramovay (1998, p.87) "o desempenho da mulher na produção familiar não é reconhecido socialmente porque o espaço 'público' continua sendo de domínio masculino". 


\subsubsection{O jovens agricultores e agriculturas do futuro}

Iniciaremos apresentando o tema inicial que demonstra a preocupação e a $\mathrm{Na}$ entrevista com o representante do ITESP (Instituto de Terras do Estado de São Paulo) que atuava na região, pudemos perceber que ele via como prioritário o desenvolvimento de algum tipo de trabalho com os jovens, apesar do trabalho deste técnico estar especificamente ligado aos agricultores, extensão rural e assistência técnica aos plantios.

"pra mim, um dos principais problemas nos assentamentos que eu trabalho é a falta de interesse dos jovens na agricultura e a saída deles do assentamento, e aqui em Iperó é igual". Cícero

"tem alguns jovens se envolvendo com o projeto de produção de mudas de pupunha (...) acho que eles vêem uma forma mais rápida de ganhar dinheiro". Cícero

" toda semana eu venho prá cá e fico um manhã só para responder perguntas sobre as dúvidas deles com a produção, mas quase não vejo jovem". Cícero

"ouvi alguns pais falando de seus filhos participar do grupo de jovens, pode ser uma saída". Cícero

Através da triangulação pudemos observar algumas linhas gerais mais presentes:

\section{a)Emprego e futuro}

Ficou claro a preocupação com o futuro dos filhos dentro do assentamento, a falta de emprego e de alternativas que pudessem satisfazer as exigências e necessidades que seus filhos apresentavam.

A falta de alternativas inclusive para a sobrevivência dos pais e irmãos menores, em muitos casos, fazia os filhos trabalharem fora para ajudar a manter a casa.

Apesar da terra, o problema de mercado e comercialização está muito presente, mais recentemente, muitos agricultores já faziam a comercialização de seus produtos em 
feiras livres, inclusive os dois grupos de jovens já estavam comercializando mel e própolis nas feiras livres.

Inclusive no final do período de campo deste trabalho, haviam outros dois grupos interessados em inciar um trabalho com produção de mel e inclusive o grupo das meninas que havia se mobilizado diversas vezes para iniciar o trabalho com as abelhas, já estava contando com o apoiio dos meninos mais experientes dos primeiros grupos de apicultura e já tinham duas caixas instaladas no seu sítio.

A vocação pela terra, foi outro fator relevante observado, muitos jovens apresentavam o desejo de ser agricultor, criador de gado, apicultor, psicultor, apresentavam com principal fator a falta de conhecimentos e de capacitação adequada, além de crédito.

"agora parece que o IBAMA vai ajuda num curso prá gente prá mexe com peixe"

"la de casa, eles num que ficá direto na enxada...queria fazê uma coisa mais fáci..." Zé

"Hojé, né nóis tá podendo vendé esse mel na fera, e olha que vende bem nois já tem a té freguês..." Márcio

\section{b)Religião, namoro e casamento precoce}

Este aspecto foi bastante levantado pelos pais, a preocupação em seguir uma religião como forma de proteção contra os perigos do mundo atual como drogas, e violência.

A realidade no assentamento demostra um grande número de fulgas de casais de namorados que fogem para casar em outro município, muitas vezes na cidade e que logo mais retornam ao assentamento e constróem suas casas nos terrenos dos pais.

Neste aspecto um dos principais problemas observados é o fato mais de $50 \%$ da comunidade do assentamento ser evangélica, portanto existindo sérias normas em relação a namoro e comportamento sexual. Outro fator é que muito pouco conhecimento em Educação sexual é passado de pais para filhos ou filhas, muitas vezes, os pais, tem dúvidas em relação a métodos anticoncepcionais e a grande maioria simplesmente não fala neste assunto. 
Pode-se notar atualmente, um grande número de casais que se formaram nestes últimos anos entre famílias de assentados. Apesar dos jovens freqüentarem as escolas de Iperó, podemos perceber em declarações e entrevistas que a escolha é por garotos e garotas do assentamento. Este fato revela a questão da identidade já criada no local, podendo ser favorável a permanência no local, por outro lado, a falta de oportunidades substantivas de trabalhos e renda, faz com que muitos casais tenham que trabalhar fora ou até mesmo mudar para a cidade em busca de alguma segurança financeira apesar de terem a terra para morar.

"a Tati si incontró aí com o César queriam casá, daí fugiram...eu mesmo não achei certo". Susi

"Filha minha tem que namorá em casa, sai só prá casá". Pastor Antonio

" a namorada engravidó, mas prá mim Cristina, eu não acho que tem que obrigá a casá...casá sem amor, prá quê? ...prá depois separá? Tem que cuidá da criança direitinho... D. Jô.

\section{c) Aspecto organizacional e o JUMAFI}

Esta linha geral deixa trás bastante transparência deixando evidente que as questões coletivos para a maioria dos pais entrevistados não está solucionada. Apresentam uma relação traumática em relação ao MST e a experiência de grupo coletivo ano momento da ocupação e acampamento. Não depositam muita confiança em projetos coletivo e a memória continua trazendo lembranças de grandes descontentamentos. A tendência é o trabalho em grupos de famílias vizinhas e em menor número de pessoas, o que ainda é bastante recente.

Em relação ao JUMAFI, gostariam de ter participado dando opiniões e contando de suas experiências na fase inicial de formação do grupo. Na fase 2 do trabalho houve intensa participação dos pais, inclusive em algumas reuniões foi necessário separarmos um tempo para reunião de pais, pois a necessidade de falar, de se expressar em relação a outros assuntos gerais do assentamento e referentes aos traumas coletivos e as chamadas lideranças negativas' que, segundo muitos dos 
pais, era o que prejudicava a realização de um trabalho coletivo em que eles pudessem apostar.

Havia também a esperança de que seus filhos pudessem se interessar pelo trabalho na terra, tentando outras alternativas.

"os menino tem outra cabeça, entendi mió, prá mim já num dá, eu tenho qui fazê desse jeito mesmo". Zé da Mariquinha

"eu sempre achei essa história de trabaiá em grupo muito ruim, prá nóis, foi cumplicado, então prá eles ia sê também". Ligeirinho

"eu sempre quis falá prá eles que era muito sonho, mas eles num ovia". Ligeirinho

"Foi muito bom o que o Maciel e a Teresa fizeram por eles, eles se uniram, era um jeito deles não saí de perto de nóis, mas quando eles foram embora, fico tudo perdido, os menino fico sem vontade". Octávia

"é... pode se que de certo, num é porque nóis num deu, que eles num vai dá né..." José Darcy

"sabe Cristina, prá nós o importante é criar alternativas pros jovens, a igreja já é uma, mas a gente precisa ganha dinheiro, porque senão eles vão embora mesmo(...) eu acredito que tem que ser em grupo, mas qual tipo de grupo? Olha, a nossa experiência foi muito ruim, teve até derramamento de sangue...hoje nóis somo o grupo dos evangélicos, assim mesmo tem problemas porque são muitas famílias, tem que ouvir todos irmão, nem sempre eles querem a mesma coisa, mas é muito melhor...nóis temos a religião em comum". Pastor Cláudio

A Igreja evangélica dentro do assentamento conta com um grupo de jovens liderados pela Sra. Jô (esposa do Pastor Sr. Cláudio), que se tornou praticamente a única forma de diversão, ou de encontro social entre os jovens do assentamento, local para os encontros.

"nóis tem que fazer alguma coisa prá agrupa esse jovem daqui de dentro, dá um caminho prá eles, né” (Dona Jô).

O grupo conta hoje com cerca de 13 jovens que fazem parte do coral da igreja e se organizam para fazer as festas comunitárias da igreja para a construção e ampliação da igreja de alvenaria em substituição do barraco de madeira. 
Nestes últimos anos muitas famílias e muitos jovens se tornaram evangélicos e se sentem mais reconhecidos socialmente, mais respeitados, porém tendo que ter certo rigor, disciplina no comportamento.

"prá mim a igreja ajudou muito, eu encontrei até uma familia, minha namorada era da igreja então prá namorá ela eu também tinha que sé”. André

"a igreja para a gente representa a união, os ensinamentos do evangélio de um caminho certo, alertando e afastando dos perigos. Para nossos jovens Ter um rumo certo”. Sr. Cláudio (pastor)

Do total de famílias no assentamento calcula-se que cerca de $60 \%$ sejam evangélicos.

Outro fator que emerge com grande intensidade, são os casamentos precoces, por volta dos 17 ou 18 anos os jovens do assentamento costumam fugir para casar, na grande maioria dos casos, eles casam-se entre eles, reforçando a rede social de segurança interna, retornam casados e normalmente constróem um barraco no lote de um dos pais, há casos de gravidez precoce.

A união entre os jovens muitas vezes pode ser vista como uma forma de independência familiar partindo para uma nova vida. Atualmente são cerca de $10 \%$ dos jovens que casaram-se com filhos de assentados, alguns deles trabalham fora pois acreditam que a agricultura não lhes trará lucro e uma boa vida, principalmente os que estudaram.

A doutrina da Igreja evangélica no assentamento trás uma série de normas a seus seguidores, disso resulta que, por exemplo, as relações sexuais sejam rigorosamente proibidas antes do casamento, em se tratando de uma comunidade muito pequena, os jovens da Igreja Evangélica tem na figura do pastor um orientador e nos irmãos da comunidade apoio para suas decisões. Portanto entre os jovens evangélicos, não se permite a prática de esportes, músicas, bailes, roupas decotadas, televisão. Porém oferecem festas na igreja, coral para os jovens, havendo um grande entrosamento e reconhecimento social entre as pessoas do grupo.

Outros atores como as escolas dos municípios vizinhos, são os locais onde eles estudam e também constróem suas relações de amizade e sociabilidade, no entanto há também traumas nestes espaços sociais devido ao preconceito existente com relação aos sem-terra, que de certo modo os desestimula e contribui para que 
haja um número maior de desistências escolares. Esta reação era mais corrente no início do acampamento como coloca uma jovem assentada.

"eu só sei que eu dava medo nas meninas, porque elas pensavam que a gente era tudo bandido, então nem queria falá com a gente, nem nada, eu tinha ódio disso, eu queria sumi”. Luciana

"é prá eles assentado não valia nada, tava estudando de favor...no começo foi difícil” Milena

No entanto essa realidade foi se modificando quando o número de jovens e crianças na escola foi aumentando e de certa maneira criando seu espaço. Uma das jovens filha de assentados já é professora da escola primária, modificando o olhar para os filhos de assentados na escola.

Este movimento de transformação na estrutura da pequena cidade de cerca de 11000 habitantes, dados do IBGE (1996) tem mudado significativamente. A economia local se modificou, o número de feiras livres na região periférica de Sorocaba aumentou, as sapatarias da cidade e loja de materiais agrícolas além dos supermercados e açougues aumentaram devido a demanda surgida pela presença do assentamento. Inclusive a oferta de produtos hortifrutigranjeiros como leite, ovos, verduras e também carne de porco, milho, mandioca e feijão, maracujá, jiló, quiabo (principais culturas nos lotes). 


\section{CONCLUSÕES}

O fato de nossa proposta de pesquisa não estar atrelada a nenhum projeto social que pudesse dar apoio financeiro e estrutural para a viabilização das muitas demandas surgidas neste processo, em muitos momentos havia desânimo, paradas dos jovens para auxiliar na roça familiar, na construção das casas de alvenaria, da escola, dos dias de chuva.

Demandas cotidianas de sobrevivência e que portanto tinham prioridade nas vidas destes jovens.

Durston (1996a e1996b) citado por Abramovay (1998, p.40) nos traz a reflexão sobre a necessidade e a dificuldade do pensamento estratégico por parte dos jovens para enfrentar novas situações de alternativas econômicas na agricultura. Trabalhos desenvolvidos por esse autor a este respeito demonstram que "é preciso diferenciar as situações nas quais a agricultura e o meio rural para os jovens são uma escolha preferencial daquelas que resultam, na verdade, da impossibilidade de realizar um projeto pessoal, seja em virtude do peso das relações patriarcais, do papel subordinado da mulher ou da possibilidade de encontrar caminhos alternativos aos horizontes atuais".

Em alguns momentos havia um estímulo forte na intervenção e coleta de dados em campo, pois era o momento da ação, onde as coisas aconteciam cotidianamente. As efervescências cotidianas.

Surgiam muitas demandas de grupos diferenciados dentro do assentamento, no entanto foi necessário em função da pesquisa fazer um corte no tempo, para finalizar as atividades em campo.

Ainda alguns desdobramentos ficaram pendentes como é o caso da necessidade que surgiu de se criar uma escola família agrícola dentro do assentamento. Para isso o Conselho se mobilizou, havia um grupo de pais e jovens 
interessados em trazer esta proposta com o objetivo de tentar concentrar essas capacitações para que outros jovens possam ter acesso a tecnologias alternativas de produção e de atividades não-agrícolas.

No entanto até o momento da nossa saída de campo, faltava motivação por parte do grupo de pais para dar continuidade a algumas atividades.

Um esforço sempre presente à prática da autoridade coerentemente democrática é o que a torna quase escrava de um sonho fundamental: o de persuadir ou convencer a liberdade que se vai construindo consigo mesma, em si mesma, com materiais que, embora vindo de fora de si, sejam reelaborados por ela, a sua autonomia. É com ela, a autonomia, penosamente construindo-se, que a liberdade vai preenchendo o "espaço" antes "habitado" por sua dependência. Sua autonomia que se funde na responsabilidade que vai sendo assumida” (Freire, 2000, 105p.)

Ao concluir esta dissertação de mestrado, percebi o número sem fim de reflexões que me foram colocadas. A experiência de campo, mínima, mas absolutamente repleta de possibilidades de reflexões teóricas, se conectou com alguns autores fantásticos, os quais pude compartilhar um diálogo riquíssimo, no qual assumi, muitas vezes, o papel de ouvinte deslumbrada, maravilhada diante das descobertas, ousei apenas escutar e tentar compreender.

Boaventura de Souza Santos, José de Souza Martins, Michel Maffesoli, Bader Sawaia, Nancy Manguabeira Unger entre outros, possibilitaram através de suas teorias, desvendar o caminho para que eu pudesse responder as perguntas iniciais em relação a esta pesquisa, sem dúvida contribuíram para o surgimento de muitas outras.

Para compreender como se dá o processo de formação e organização de grupos de jovens e as alternativas de geração de renda no local, foi necessário entrar em diferentes áreas do conhecimento para ir buscando uma referência para as etapa vista em campo.

Foi necessário perceber o paradigma sob o qual todos os acontecimentos em campo estavam se dando, e buscar explicações coerentes junto aos sentimentos e reações dos grupos de jovens.

Descobri em Santos, que substituir a visão da utopia para uma heterotopia tornava-se essencial para compreender a realidade social pesquisada, apresentando a 
capacidade de incorporar a diversidade, questionando o paradigma da modernidade e a força homogenizadora que carrega para se estabelecer e convencer.

Os conceitos de liberdade de escolha, de emancipação social e as oportunidades necessárias para o jovem agricultor assentado no contexto estudado, remetem a reflexões políticas sobre o paradigma da modernidade, pois, muitas vezes, tem-se a ilusão de que estes direitos mínimos de cidadania, utilizados como símbolos, poderiam ser alcançados através deste sistema político no paradigma dominante. Spozzati (2001, p. 18) analisando Santos, reflete a este respeito, referindo a maneira com que são tratados os movimentos que denunciam esta dominação ou exploração que levam ao fracasso deste modelo, lembrando que o MST é mostrado como destruidor da ordem, agitador, desconectado dos "valores desejados pela sociedade", resta indagar quem faz parte dessa sociedade com incluído ou excluído. Segundo a autora, muitos destes movimentos sociais são considerados a "vanguarda do atraso".

Acredito que os jovens participantes desta pesquisa encontravam-se justamente no meio deste conflito, ao buscar construir uma nova possibilidade de agrupamento social e alternativa de geração de renda, demonstravam, por um lado, a dificuldade de conviver com a história política em que foram praticamente criados, ou seja, a formação de um assentamento rural, o fazer-parte de um movimento social como o MST e também o papel de jovem agricultor que busca se estabelecer economicamente no local e, de outro lado, a força homogenizadora existente no paradigma atual, explicitado através, como mencionado anteriormente, pelos "valores desejados pela sociedade".

O processo de formação de grupos reflete em campo, este conflito, e os desafios da ação coletiva deparam-se com dificuldades internas peculiares da vida juvenil,

Surge neste contexto a necessidade de se buscar parceiros que acreditem na formação de um novo paradigma social, em uma utopia emancipatórira, o paradigma ecossocialista (Santos, 1995).

Acredito que as práticas em Educação Ambiental representam hoje, a possibilidade desta heterotopia, desta visão diferenciada da realidade para a 
construção desta nova utopia, reforçando a necessidade de um referencial teórico consolidado nos diferentes temas que a compõe. 
ANEXOS 


\title{
ANEXO I PLANO DE ATIVIDADES DO JUMAFI
}

\author{
JUMAFI - Jovens Unidos de Mobilizaçāo da Fazenda Ipanema
}

PLANOS MENSAIS

Mês de julho de 1997

\begin{tabular}{|c|c|c|c|}
\hline 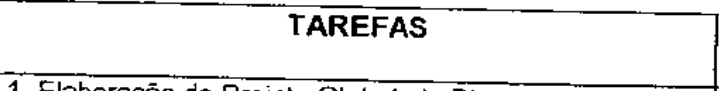 & EPOCA & $\begin{array}{c}\text { EQUIPE } \\
\text { RESP. }\end{array}$ & $\begin{array}{l}\text { HORÁRIO } \\
\text { DE TRAB }\end{array}$ \\
\hline $\begin{array}{l}\text { 1- Elaboraçäo do Projeto Global, do Plano de Manejo da } \\
\text { Reserva, dos documentos básicos do JUMAFI; dos } \\
\text { Planos de Atividades, dos Projetos de Produçảo }\end{array}$ & mês inteiro & & \\
\hline $\begin{array}{l}\text { 2- Contato com Instituiçöes p/ cursos para o JUMAFI : } \\
\text { - com a Mônica (ESALQ/Itatinga - curso de Shiitake) } \\
\text { - CAPIDE (cursos de apicultura e ervas medicinais) } \\
\text { - ESALQ (NACESALQ) outros cursos: informática, ed. } \\
\text { ambiental, agrossilvicultura, ervas medicinais, reciclagem } \\
\text { de lixo etc. }\end{array}$ & $\begin{array}{l}\text { início de jul. } \\
14 / 07 / 97 \ldots \ldots . . \\
21 / 07 / 97 \ldots \ldots . \\
\end{array}$ & & \\
\hline 3- Apresentaça do projeto ao DEPRN & & & \\
\hline $\begin{array}{l}\text { 4- Apresentaçāo do Projeto ao Conselho da Faz. pl } \\
\text { aprovaçăo }\end{array}$ & & & \\
\hline 5- Repasse dos Cursos feitos - Shiitake & $12 / 07 / 97$ & & \\
\hline 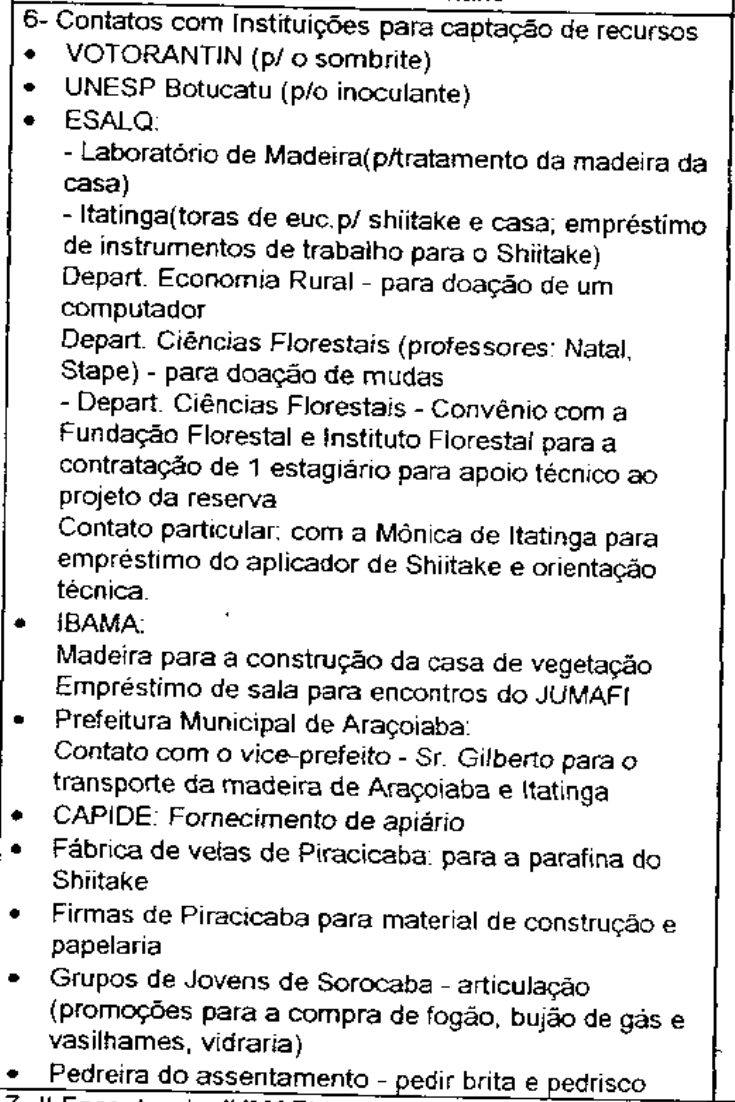 & mês inteiro & & \\
\hline $\begin{array}{l}\text { 7- II Encontro do JUMAFI } \\
\text { Definir formas de organizaçāo }\end{array}$ & 18 e $19 /$ jutho & $\begin{array}{l}\text { JUMAFI } \\
\text { e apoio }\end{array}$ & $\begin{array}{l}08: 00 \text { às } \\
18: 00 \text { hs }\end{array}$ \\
\hline
\end{tabular}


MÊS DE AGOSTO/97

\begin{tabular}{|c|c|c|c|}
\hline TAREFAS & ÉPOCA & $\begin{array}{c}\text { EQUIPE } \\
\text { RESP }\end{array}$ & $\begin{array}{l}\text { HORÁRIO } \\
\text { DE TRAB }\end{array}$ \\
\hline $\begin{array}{l}\text { Área de Convivência } \\
\text { Limpar a área do convivência } \\
\text { Roçar a área da praça } \\
\text { Construção da casa } \\
\text { Construção dos móveis } \\
\text { Instalar a caixa d'água }\end{array}$ & & & \\
\hline $\begin{array}{l}\text { Área de Trabalho } \\
\text { Construção do barracāo } \\
\text { Roçar } \\
\text { Instalar a água do viveiro e do Shiitake } \\
\text { Cobertura do solo do viveiro com pedrisco } \\
\text { Preparo da composteira } \\
\text { Plantio das cercas-vivas entre a praça e a área } \\
\text { de floresta }\end{array}$ & & & \\
\hline $\begin{array}{l}\text { - Área da Floresta } \\
\text { Roçar }\end{array}$ & & & \\
\hline $\begin{array}{l}\text { - Organizaçāo da Secretaria do JUMAFI } \\
\text { Livro de registro de doações com recibos } \\
\text { Ata de reuniōes } \\
\text { Projetos } \\
\text { Apostilas, folhetos, livros } \\
\text { Livro de registro das horas de trabalho (a partir } \\
\text { de agosto) } \\
\text { Cartas de agradecimento pelas doações } \\
\text { recebidas e cursos realizados } \\
\text { Preparar horários semanais de trabaho } \\
\text { Preparar fichas de inscrição e termo de } \\
\text { compromisso do JUMAFi } \\
\text { Lista de aniversariantes do assentamento }\end{array}$ & & & \\
\hline $\begin{array}{l}\text { Cursos } \\
\text { - de apicultura - } 4 \text { Jumafianos pela CAPIDE } \\
\text { - curso de informática na ESALQ (a definir) }\end{array}$ & & & \\
\hline
\end{tabular}


MÊS DE SETEMBRO/97

\begin{tabular}{|c|c|c|c|}
\hline TAREFAS & ÉPOCA & $\begin{array}{c}\text { EQUJPE } \\
\text { RESP }\end{array}$ & $\begin{array}{l}\text { HORÁRIO } \\
\text { DE TRAB }\end{array}$ \\
\hline - Festa de aniversariante do mês & & & \\
\hline $\begin{array}{l}\text { - Na área de convivência: } \\
\text { Acabar a casa: telhado e acabarnentos } \\
\text { Preparar o jardim (grama, plantas e cerca } \\
\text { separando a área de trabalho e a de } \\
\text { convivência) }\end{array}$ & & & \\
\hline $\begin{array}{l}\text { - Na área de trabalho } \\
\text { 1- produçäo de mudas } \\
\text { preparar canteiros } \\
\text { preparar sementes e plantá-las nos saquinhos } \\
\text { (plantar pinheirinho de Natal e omamentais) } \\
\text { molhar as mudas } \\
\text { 2- Shiitake } \\
\text { cortar a madeira em itatinga } \\
\text { receber as madeiras e armazená-las } \\
\text { fazer a casa de vegetaçäo } \\
\text { buscar o inoculante na UNEsP de Botucatu } \\
\text { preparar o material p/ inoculação no dia } \\
\text { marcado com a Mônica } \\
\text { Inocular a madeira } \\
\text { manter as madeiras molhadas e vistoriar a } \\
\text { casa de vegetação } \\
\text { 3- Apicultura } \\
\text { fazer os suportes para as colméias } \\
\text { preparar } 4 \text { caixas com cera alveolada } \\
\text { capturar } 4 \text { enxames } \\
\text { vistoriar as colmeias } \\
\text { 4- Arborizar a área com frutiferas }\end{array}$ & $\cdot$ & & \\
\hline $\begin{array}{l}\text { Na área de floresta } \\
\text { receber mudas doadas } \\
\text { plantar as mudas de ávores } \\
\text { plantios agrícolas }\end{array}$ & & & \\
\hline
\end{tabular}


MÊS DE OUTUBRO/97

\begin{tabular}{|c|c|c|c|}
\hline TAREFAS & ÉPOCA & $\begin{array}{c}\text { EQUIPE } \\
\text { RESP } \\
\end{array}$ & $\begin{array}{l}\text { HORÁRIO } \\
\text { DE TRAB }\end{array}$ \\
\hline - Festa de aniversariante do mês & & & \\
\hline $\begin{array}{l}\text { Na área de convivência: } \\
\text { Limpeza da casa } \\
\text { Corte da grama e cuidados com o jardim e a } \\
\text { praça } \\
\text { Fazer e instalar brinquedos na praça } \\
\text { Inaugurar o Centro de Convivência e Educação } \\
\text { Ambiental com: } \\
\text { brincadeiras na praça, teatro, gincana, produção } \\
\text { de folheto } \\
\text { Organizar a secretaria e biblioteca (cartas para } \\
\text { editoras) } \\
\text { Organizar a tesouraria }\end{array}$ & & & . \\
\hline $\begin{array}{l}\text { Na área de trabalho } \\
\text { 1- Limpeza da área } \\
\text { 2- Shiitake } \\
\text { manter as madeiras molhadas } \\
\text { vistoriar a casa de vegetação } \\
\text { 3- Apicultura } \\
\text { vistoriar as coimeias } \\
\text { 4- Produção de mudas } \\
\text { irrigar } \\
\text { fazer a monda } \\
\text { fazer outra composteira }\end{array}$ & & & \\
\hline - Curso de ervas medicinais na CAPIDE & & & \\
\hline - Repasse do curso de enas para o interessados & & & \\
\hline $\begin{array}{l}\text { - Articular a comercialização: } \\
\text { - Shiitake } \\
\text { - Mel } \\
\text { - abobora, melão, melancia, feijāo etc. } \\
\text { - mudas } \\
\text { - ervas medicinais }\end{array}$ & & & \\
\hline
\end{tabular}


MÉS DE NOVEMBRO/97

\begin{tabular}{|c|c|c|c|}
\hline 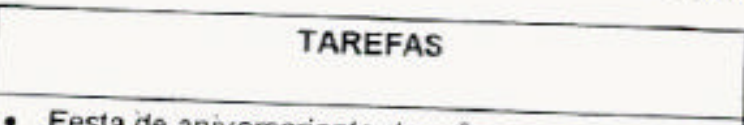 & ÉPOCA & $\begin{array}{c}\text { EQUIPE } \\
\text { RESP }\end{array}$ & $\begin{array}{l}\text { HORÁRIO } \\
\text { DE TRAB }\end{array}$ \\
\hline - Festa de aniversariante do mês & & & \\
\hline $\begin{array}{l}\text { - Na área de convivência: } \\
\text { Limpeza da casa } \\
\text { Corte da grama e cuidados com o jardim e a } \\
\text { praça } \\
\text { Organizar a secretaria e biblioteca (continuação) } \\
\text { Organizar a tesouraria (continuação) } \\
\text { - Na área de traholho }\end{array}$ & & & \\
\hline $\begin{array}{l}\text { - Na área de trabalho } \\
\text { 1- Limpeza da área } \\
\text { 2- Shiitake } \\
\text { manter as madeiras molhadas } \\
\text { vistoriar a casa de vegetação } \\
\text { 3- Apicultura } \\
\text { vistoriar as colmeias } \\
\text { 4- Produção de mudas } \\
\text { irnigar } \\
\text { fazer a monda } \\
\text { racarregar as composteiras } \\
\text { 5- Ervas medicinais } \\
\text { preparar o solo e plantar as mudas }\end{array}$ & & & \\
\hline $\begin{array}{l}\text { - Na área de floresta } \\
\text { colheita de produtos agricolas (feijăo, abóbora } \\
\text { etc) } \\
\text { preservar a cobertura morta no solo } \\
\text { plantar uma leguminosa nos espaços vazios } \\
\text { (soja) } \\
\text { roçar capim }\end{array}$ & & 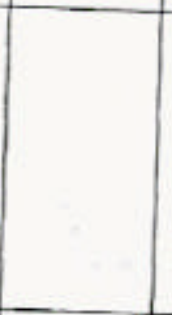 & \\
\hline $\begin{array}{l}\text { Comercialização: } \\
\text { produtos agricolas } \\
\text { mudas }\end{array}$ & & & \\
\hline $\begin{array}{l}\text { Preparação da campanha de dezembro: "Plante } \\
\text { Árvores e Flores" }\end{array}$ & & & \\
\hline
\end{tabular}


MÊS DE DEZEMBRO/97

\begin{tabular}{|c|c|c|c|}
\hline TAREFAS & ÉPOCA & $\begin{array}{c}\text { EQUIPE } \\
\text { RESP } \\
\end{array}$ & $\begin{array}{l}\text { HORÁRIO } \\
\text { DE TRAB }\end{array}$ \\
\hline - Festa de aniversariante do mës & & & \\
\hline $\begin{array}{l}\text { Na área de convivência: } \\
\text { Limpeza da casa } \\
\text { cuidados com o jardim, grama e praça } \\
\text { Inaugurar a biblioteca: produçāo de folhetos e } \\
\text { hora do conto para crianças } \\
\text { Início da campanta "Plante árvores e Flores" - } \\
\text { curso: "recuperação, conservação e } \\
\text { aproveitamento econômico das reservas" e } \\
\text { folheto: O valor das árvores (a ser distribuído na } \\
\text { venda das mudas) } \\
\text { Preparar a programação da abertura do ano de } \\
\text { 1998 } \\
\text { Um dia de arte na reserva (1998 com } \\
\text { criatividade e amor a natureza) }\end{array}$ & & & \\
\hline $\begin{array}{l}\text { Na área de trabalho } \\
\text { 1- Limpeza da área } \\
\text { 2- Shiitake } \\
\text { manter as madeiras molhadas } \\
\text { vistoriar a casa de vegetaçāo } \\
\text { 3- Apicultura } \\
\text { vistoriar as colmeias } \\
\text { 4- Produçāo de mudas } \\
\text { irigar } \\
\text { fazer a monda } \\
\text { manutençāo das composteiras }\end{array}$ & & & \\
\hline $\begin{array}{l}\text { Na área de floresta } \\
\text { colheita de produtos agricolas (melāo, melancia } \\
\text { etc.) } \\
\text { preservar a cobertura morta no solo } \\
\text { plantar uma leguminosa nos espaços vazios } \\
\text { (amendoim) } \\
\text { roçar capim }\end{array}$ & & & \\
\hline $\begin{array}{l}\text { Comercialização: } \\
\text { produtos agricolas } \\
\text { mudas (pinheirinho de Natal) }\end{array}$ & & & \\
\hline
\end{tabular}


MÊS DE JANEIRO/98

\begin{tabular}{|c|c|c|c|}
\hline TAREFAS & ÉPOCA & $\begin{array}{c}\text { EQUIPE } \\
\text { RESP }\end{array}$ & $\begin{array}{l}\text { HORÁRIO } \\
\text { DE TRAB }\end{array}$ \\
\hline - Festa de aniversariante do mês & & & \\
\hline $\begin{array}{l}\text { - Na área de convivência: } \\
\text { Limpeza da casa } \\
\text { Corte da grama e cuidados com o jardim e a } \\
\text { praça } \\
\text { Manutenção da casa (consertos, reformas, } \\
\text { pintura etc.) } \\
\text { Comemoração do ano novo - Um dia de arte na } \\
\text { reserva (10 a 14) } \\
\text { Atividades de Educ. Ambiental (pintura, } \\
\text { desenho, escultura com sucata e argila) }\end{array}$ & & & \\
\hline $\begin{array}{l}\text { Na área de trabalho } \\
\text { 1- Limpeza da área } \\
\text { 2- Shiitake } \\
\text { manter as madeiras molhadas } \\
\text { vistoriar a casa de vegetação } \\
\text { 3- Apicultura } \\
\text { vistoriar as colmeias } \\
\text { Primeira colheita: centrifugar, embalar e } \\
\text { etiquetar } \\
\text { 4- Produçāo de mudas } \\
\text { irrigar } \\
\text { fazer a monda } \\
\text { semear novas sementes } \\
\text { manutenção das composteiras } \\
\text { 5- Ervas medicinais } \\
\text { Colheita, secagem, embalagem e } \\
\text { armazenamento }\end{array}$ & & & \\
\hline $\begin{array}{l}\text { - Comercialização: } \\
\text { - mel } \\
\text { - mudas } \\
\text { - ervas medicinais } \\
\end{array}$ & & & \\
\hline
\end{tabular}


MÉs DE FEVEREIRO/98

\begin{tabular}{|c|c|c|c|}
\hline TAREFAS & ÉPOCA & $\begin{array}{c}\text { EQUIPE } \\
\text { RESP } \\
\end{array}$ & $\begin{array}{l}\text { HORÁRIO } \\
\text { DE TRAB }\end{array}$ \\
\hline - Festa de aniversariante do mês & & & \\
\hline $\begin{array}{l}\text { - Na área de convivência: } \\
\text { Limpeza da casa } \\
\text { Corte da grama e cuidados com o jardim e a } \\
\text { praça }\end{array}$ & & & \\
\hline $\begin{array}{l}\text { Na área de trabalho } \\
\text { 1- Limpeza da área } \\
\text { 2- Shiitake } \\
\text { quebra de dormência, } \\
\text { irrigação } \\
\text { 3- Apicultura } \\
\text { vistoniar as colmeias } \\
\text { 4- Produção de mudas } \\
\text { irrigar } \\
\text { fazer a monda } \\
\text { produção de mais mudas } \\
\text { manutenção das composteiras }\end{array}$ & & & \\
\hline $\begin{array}{l}\text { - Comercialização: } \\
\text { - Shiitake } \\
\text { - mudas }\end{array}$ & & & \\
\hline
\end{tabular}


MẼS DE MARÇO/98

\begin{tabular}{|c|c|c|c|}
\hline - Festa de anivamacionto & ËPOCA & $\begin{array}{c}\text { EQUIPE } \\
\text { RESP }\end{array}$ & $\begin{array}{l}\text { HORÁRIO } \\
\text { DE TRAB }\end{array}$ \\
\hline - Festa de aniversariante do mês & & & \\
\hline $\begin{array}{l}\text { - Na área de convivência: } \\
\text { Limpeza da casa } \\
\text { Corte da grama e cuidados com o jardim e a } \\
\text { praça } \\
\text { Preparo da campanha: "Vamos fazer una } \\
\text { agricultura saudável" que irá até } 16 \text { de junho (dia } \\
\text { do meio ambiente) - contato com Associaçāo de } \\
\text { Agricultura Orgânica de SP } \\
\text { Na área de trabalhn }\end{array}$ & & & \\
\hline $\begin{array}{l}\text { Na área de trabaiho } \\
\text { 1- Limpeza da área } \\
\text { 2- Shiitake } \\
\text { quebra de dormência, } \\
\text { irrigação } \\
\text { 3- Apicultura } \\
\text { vistoriar as colmeias } \\
\text { 4- Produção de mudas } \\
\text { irrigar } \\
\text { fazer a monda } \\
\text { manutenção das composteiras } \\
\text { produzir pinheirinhos de Natal }\end{array}$ & & & \\
\hline $\begin{array}{l}\text { - Na area de Floresta } \\
\text { Colheita do amendoim } \\
\text { plantar oufra leguminosa }\end{array}$ & & & \\
\hline $\begin{array}{l}\text { Comercialização: } \\
\text { - Shiitake } \\
\text { - mudas } \\
\text { - amendoim }\end{array}$ & & & \\
\hline
\end{tabular}


MÊS DE ABRIL/98

\begin{tabular}{|c|c|c|c|}
\hline - Festa de anivemarianto & ÉPOCA & $\begin{array}{c}\text { EQUIPE } \\
\text { RESP }\end{array}$ & $\begin{array}{l}\text { HORÁRIO } \\
\text { DE TRAB }\end{array}$ \\
\hline - Festa de aniversariante do mês & & & \\
\hline $\begin{array}{l}\text { Na área de convivência: } \\
\text { Limpeza da casa } \\
\text { Corte da grama e cuidados com o jardim e a } \\
\text { praça } \\
\text { Inicio da campanha: "Vamos fazer uma } \\
\text { agricultura saudável" que irá até } 16 \text { de junho (dia } \\
\text { do meio ambiente) - Curso de agricultura } \\
\text { orgânica }\end{array}$ & & & \\
\hline $\begin{array}{l}\text { Na área de trabalho } \\
\text { 1- Limpeza da área } \\
\text { 2- Shiitake } \\
\text { quebra de dormência, } \\
\text { irrigação } \\
\text { 3- Apicultura } \\
\text { vistoriar as coimeias } \\
\text { implantar mais } 8 \text { caixas } \\
\text { 4- Produção de mudas } \\
\text { imigar } \\
\text { fazer a monda } \\
\text { manutenção das composteiras }\end{array}$ & & & \\
\hline $\begin{array}{l}\text { - Comercializaçäo: } \\
\text { - Shiitake } \\
\text { - mudas }\end{array}$ & & & \\
\hline
\end{tabular}


MÊS DE MAIO/98

\begin{tabular}{|c|c|c|c|}
\hline - Fectada ani- - - - & ÉPOCA & $\begin{array}{c}\text { EQUIPE } \\
\text { RESP }\end{array}$ & $\begin{array}{l}\text { HORÁRIO } \\
\text { DE TRAB }\end{array}$ \\
\hline - Festa de aniversariante do mês & & & \\
\hline $\begin{array}{l}\text { Na área de convivência: } \\
\text { Limpeza da casa } \\
\text { Corte da grama e cuidados com o jardim e a } \\
\text { praça } \\
\text { Continuação da campantia: "Vamos fazer uma } \\
\text { agricultura saudável" que irá até } 16 \text { de junho (dia } \\
\text { do meio ambiente) }\end{array}$ & & & \\
\hline $\begin{array}{l}\text { - Na área de trabalho } \\
\text { 1- Limpeza da área } \\
\text { 2- Shiitake } \\
\text { quebra de dormência, } \\
\text { irrigaçāo } \\
\text { 3- Apicultura } \\
\text { vistoriar as colmeias } \\
\text { 4- Produção de mudas } \\
\text { irrigar } \\
\text { fazer a monda } \\
\text { manutenção das composteiras }\end{array}$ & & & \\
\hline $\begin{array}{l}\text { - Comercialização: } \\
\text { - Shiitake } \\
\text { - mudas }\end{array}$ & & & \\
\hline
\end{tabular}


MÊS DE JUNHO/98

\begin{tabular}{|c|c|c|c|}
\hline TAREFAS & ÉPOCA & $\begin{array}{c}\text { EQUIPE } \\
\text { RESP } \\
\end{array}$ & $\begin{array}{l}\text { HORÁRIO } \\
\text { DE TRAB }\end{array}$ \\
\hline - Festa de aniversariante do més & & & \\
\hline $\begin{array}{l}\text { - Na área de convivência: } \\
\text { Limpeza da casa } \\
\text { Corte da grama e cuidados com o jardim e a } \\
\text { praça } \\
\text { Fim da campanha: "Vamos fazer uma agricultura } \\
\text { saudável" que irá até } 16 \text { de junho (dia do meio } \\
\text { ambiente) }\end{array}$ & & & \\
\hline $\begin{array}{l}\text { Na área de trabalho } \\
\text { 1- Limpeza da área } \\
\text { 2- Shiitake } \\
\text { quebra de dormência, } \\
\text { irrigaçăo } \\
\text { 3- Apicultura } \\
\text { vistoriar as colmeias } \\
\text { 4- Produção de mudas } \\
\text { irrigar } \\
\text { fazer a monda } \\
\text { manutenção das composteiras }\end{array}$ & & & \\
\hline $\begin{array}{l}\text { - Comercialização: } \\
\text { - Shiitake } \\
\text { - mudas } \\
\end{array}$ & & & \\
\hline
\end{tabular}


MÉS DE JULHO/98

\begin{tabular}{|c|c|c|c|}
\hline TAREFAS & EPOCA & $\begin{array}{c}\text { EQUIPE } \\
\text { RESP }\end{array}$ & $\begin{array}{l}\text { HORÁRIO } \\
\text { DE TRAB }\end{array}$ \\
\hline - Festa de aniversariante do mès & & & \\
\hline $\begin{array}{l}\text { - Na área de convivência: } \\
\text { Limpeza da casa } \\
\text { Cuidados com o jardim e a praça } \\
\text { Avaliação, replanejamento e balanço contábil. } \\
\text { Eleição da nova diretoria }\end{array}$ & & & \\
\hline $\begin{array}{l}\text { Na área de trabalho } \\
\text { 1- Limpeza da área } \\
\text { 2- Shiitake } \\
\text { irrigaçāo } \\
\text { 3- Apicultura } \\
\text { vistoriar as colmeias } \\
\text { 4- Produçāo de mudas } \\
\text { irrigar } \\
\text { fazer a monda } \\
\text { manutenção das composteiras }\end{array}$ & & & \\
\hline $\begin{array}{l}\text { - Comercializaçâo: } \\
\text { (mês sem atividades) }\end{array}$ & & & \\
\hline
\end{tabular}




\section{ANEXO II MAPA DA REGIÃO DO ASSENTAMENTO DA FAZENDA IPANEMA}
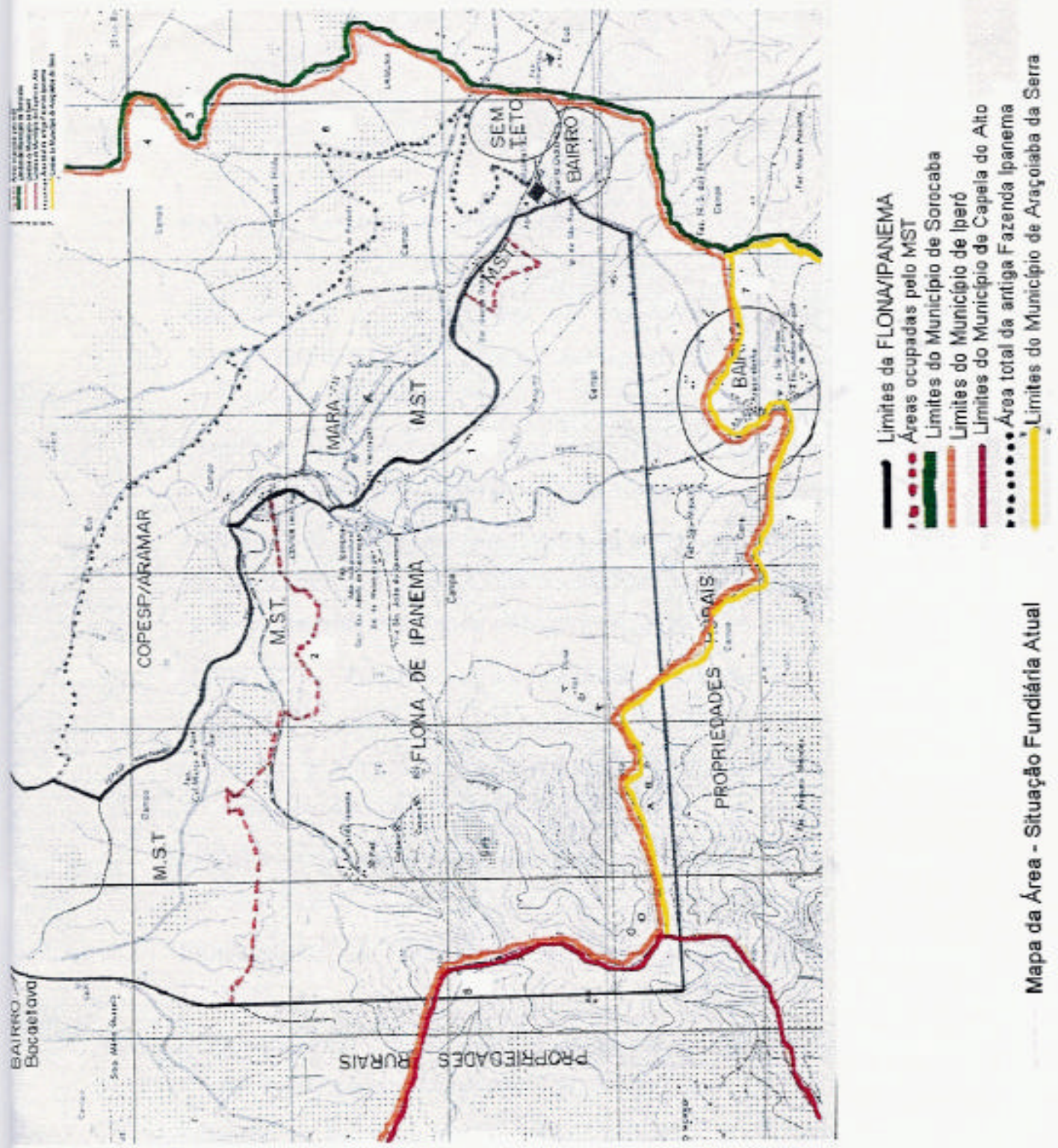

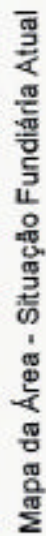




\section{REFERÊNCIAS BIBLIOGRÁFICAS}

ABRAMOVAY, R.; SILVESTRO, M.; CORTINA, N. et al. Juventude e Agricultura Familiar, desafios dos novos padrões sucessórios. Brasília: UNESCO, 1998. 104p.

AMMOUR, T. Proyecto "Conservación para el Desarrollo Sostenible en America Central”(OLAFO). Turrialba/Costa Rica: CATIE,1999. 1v.

ARDOINO, J. Abordagem multirreferencial (plural) das situações educativas e formativas. In: BARBOSA, J.G. (Coord.) Multirreferencialidade nas ciências e na Educação. São Carlos: UFSCar, 1998. 24-49.

BARBIER, R. Pesquisa-ação na instituição educativa. Rio de Janeiro: Jorge Zahar, 1985. 280p.

BARBOSA, J. G. (Coord.) Multirreferencialidade nas ciências e na educação. São Carlos: UFSCar, 1998.

BECKER, H. Métodos de pesquisa em ciências sociais. São Paulo: HUCITEC, 1993. 178p.

BERGAMASCO, S. P. O que são assentamentos rurais. São Paulo: Brasiliense, 1996. 1v.

BERGAMASCO, S. P. A realidade dos assentamentos por detrás dos números. Revista de Estudos Avançados, n.31, Set/Dez, 1997.

BERGER, P.; LUCKMANN, T. A construção social da realidade: tratado de sociologia do conhecimento. Petrópolis: Vozes, $15^{\mathrm{a}}$ ed., 1998. 247p.

BOFF, L. Ecologia, grito da terra, grito dos pobres. São Paulo: Ática, 1995. $341 \mathrm{p}$. 
BOFF, L. Saber cuidar: ética do humano-compaixão pela terra. Petrópolis: Vozes, 1999. 1v.

BOURDIE, P. O desencantamento do mundo: estruturas econômicas e estruturas temporais. São Paulo: Perspectiva, 1979. 135p. 1v.

BRANCO, M. T. C. Os jovens sem terra: identidades em movimento. São Paulo, 1999. 201p. - Tese (Doutorado) - UFSC .

BRANDÃO, C.R. Aprendendo a Fazer Melhor Através da Ação". In: Carlos Rodrigues Brandão (org). Pesquisa Participante. São Paulo, Brasiliense, 1981.

CAMPOS, R. H. F. (Org.) Da solidariedade à autonomia. Petrópolis: Vozes, 1996. 179 p.

CAPRA, F. O ponto de mutação: a ciência, a sociedade e a cultura emergente. São Paulo: Cultrix, 1982. 447p.

CAPRA, F. A Teia da Vida. 9 ed. São Paulo: Cutrix, 1996. 1v.

CARVALHO, E. A. Ética, solidariedade e complexidade. São Paulo: Palas Athenas, 1998. 77p.

CASCINO, F.; JACOBI, P.; OLIVEIRA, J.F. Educação, meio ambiente e Cidadania: reflexões e experiências. São Paulo: SEMA,CEAM, 1998. 122p.

CASTEL, R. As metamorfoses da questão social: uma crônica do salário. São Paulo: Vozes, 1998. 611 p.

CASTELlS, M. O poder da identidade, a era da informação: economia, sociedade e cultura. São Paulo: Paz e Terra, 1999. 529p.

CARRETEIRO, T.C. "A doença como projeto"- uma contribuição à análise de formas de filiações e desfiliações sociais. In: SAWAIA, B. (Org.) As artimanhas da exclusão: análise psicossocial e ética da desigualdade social. Petrópolis: Vozes, 1999. p. 87-95.

COLON, A. Etnometodologia e multirreferencialidade. In: BARBOSA, J.G. (Coord.) Multirreferencialidade nas ciências e na educação. São Carlos: UFSCar, 1998. p.149-158. 
CHAUÍ, M. Amizade, recusa do servir: comentários sobre o discurso da servidão voluntária. São Paulo: Brasiliense, 1999. 66p.

DEMO, P. Participação e avaliação. In: SORRENTINO, M. (Coord.) Ambientalismo e participação na contemporaneidade. São Paulo: EDUC; FAPESP, 2001. p. 163-184.

DIAS, G.F. Educação Ambiental: princípios e práticas. São Paulo: Gaia, 1995.

DIEGUES, A. C. O mito moderno da natureza intocada. São Paulo: HUCITEC, 1996. 1v.

D’INCAO, M. C.; ROY, G. Nós cidadãos: ensinando e aprendendo a democracia. São Paulo: Paz e Terra, 1995. 277p.

FERREIRA, L.da C. Ambientalismo brasileiro nos anos 1990: crise e oportunidade de mudança social. In: SORRENTINO, M. (Coord.) Ambientalismo e participação na contemporaneidade. São Paulo: EDUC; FAPESP, 2001. p.5783.

FONTAS, C. La técnica de los grupos focales en el marco de la investigación socio - cualitativa. http://www.fhumyar.unr.edu.ar/ciencias-educaciontc/articulos/articulo4.htm ( nov. 2001).

FREIRE, P. Política e educação: ensaios. São Paulo: Cortez, 1993. 119p.

FREIRE, P. Pedagogia da autonomia. São Paulo: Paz e Terra, 2000. 165p.

FROMM, E. Caráter social de uma aldeia: um estudo sociopsicoanalítico. Rio de Janeiro: Jorge Zahar, 1972. 378p.

FUENTES, S. Grupos focales: a experiência en la República de Guatemala.

http://www.qaproject.org/pdf/guatfocus.pdf. ( nov. 2001)

GEILFUS, F. 80 herramientas para el desarrollo participativo: diagnóstico, planificación, monitoreo y evaluación. San Salvador: Proyecto de Cooperación IICA/GTZ, 1997. 208p.

GOHN, M. G. Os sem-terra, ONG's e cidadania: a sociedade brasileira na era da globalização. São Paulo: Cortez, 1997. 172p. 
GONÇALVES, C. W. P. Educador ambiental, educador. In: WWF BRASIL. (Org.) Educador ambiental: seis anos de experiência. São Paulo, 2000.

GONÇALVES, C.W.P. Meio ambiente, ciência e poder: diálogo de diferentes matrizes de racionalidade. In: SORRENTINO, M. (Coord.) Ambientalismo e participação na contemporaneidade. São Paulo: EDUC; FAPESP, 2001. p.135-161.

GONDOLO, G. Desafios de um sistema complexo à gestão ambiental: bacia do guarapiranga, região metropolitana de São Paulo. São Paulo: Anna Blume, 1999. 162p.

GRAZIANO da SILVA, J. Por uma reforma agrária não essencialmente agrícola. Agroanalysis, v.16, n.3, p.8-11, mar. 1996.

GRÜN, M. Ética e educação ambiental: a conexão necessária. Campinas: Papirus, 1996. $120 \mathrm{p}$.

HOBSBAWN, E. Era dos extremos: o breve século XX. São Paulo: Cia. das Letras, 1994. 1v.

JUNQUEIRA, R.G. P. A intersetorialidade do ponto de vista da Educação Ambiental. Revista de Administração Pública, v.32, n.2, p.79-91, mar./abr. 1998.

JACOBI, P. Meio Ambiente e redes sociais: dimensões intersetoriais e complexidade na articulação de práticas coletivas. Revista de Administração Pública, v. 32, n.2, p.131-158, mar./abr. 1998.

KAPLUN, M. El comunicador popular. In: CURSO INTERNACIONAL DE DESAROLLO RURAL, Turrialba, 1999. Anais: Turrialba: CATIE. 1v.

LA BOÉTIE, E. Discurso da servidão voluntária. São Paulo: Brasiliense, 1982. $239 p$.

LARGE, M. Eco-mapping - how to avoid boiled frogs. NPI - Bulletin, p.14-18, 1991. 
LAPASADE, G. Da multirreferencialidade como bricolagem. In: BARBOSA, J.G. (Coord.) Multirreferencialidade nas ciências e na educação. São Carlos: UFSCar, 1998. p.126-148.

LINHARES, M. Y.; SILVA, F. C. Terra prometida: uma história da questão agrária no Brasil. Rio de Janeiro: Campus, 1999. 211 p.

LHULLIER, L. Autoritarismo, democracia e consciência moral: uma perspectiva psico-política. In: CAMINO, L.; LHULLIER, L.; SANDOVAL, S.(Org.) Estudos sobre comportamento político: teoria e pesquisa. Florianópolis: Letras Contemporâneas, 1997. p.25-38.

LÜDKE, M.; ANDRÉ, M.E.D.A Pesquisa em educação: abordagens qualitativas. São Paulo: E.P.U., 1986. 100p.

LUNA, S. V. Planejamento de pesquisa: uma introdução. São Paulo: EDUC, 1998. 108p.

MACHADO, A. M. B. A produção do saber sobre a floresta pelos assentados da Fazenda Ipanema, Iperó (SP). Piracicaba, 1998. 129p. Dissertação (Mestrado) Escola Superior de Agricultura “Luiz de Queiroz”, Universidade de São Paulo.

MAFFESOLI, M. No fundo das aparências. Petrópolis: Vozes, 1996. 350p.

MAFFESOLI, M. A transfiguração do político: a tribalização do mundo. Porto Alegre: Slina, 1997. 304p.

MARTINS, J.S. Sociologia e militância. Revista Estudos Avançados, v.31, n.11, p.137-188, 1997.

MASSELLI, M. C. Extensão rural entre os sem-terra. Piracicaba: UNIMEP, 1998. 165p.

MATURAnA, H. A ontologia da realidade. Belo Horizonte: UFMG, 1997. 350p.

MELO, A. L. P. Das intenções de desenvolver aos processos de desenvolvimento: a reestruturação fundiária na região de Conceição do Araguaia/PA. Rio de Janeiro, 1998. 237p. Dissertação (Mestrado) - Universidade Federal do Rio de Janeiro. 
MINAYO, M. C. S. (Org.) Pesquisa social: teoria, método e criatividade. Pétropolis: Vozes, 1994. 80p.

MOITINHO, W. A “ocupação" da Fazenda Ipanema pelos trabalhadores rurais 'sem-terra: uma pequena análise . Piracicaba: s.ed., 1995.

MORIN, E. Introdução ao pensamento complexo. Lisboa: Instituto Piaget, 1990. $177 \mathrm{p}$.

MORIN, E. O problema da epistemologia da complexidade. Lisboa: EuropaAmérica, 1996. 135p.

MORIN, E. Amor, poesia e sabedoria. Rio de Janeiro: Bertrand Brasil, 1998. $72 \mathrm{p}$.

MORIN, E. Os sete saberes necessários à educação do futuro. São Paulo: Cortez, 2001. 118p.

MORIN, E. O método I: a natureza da natureza. 3.ed. Lisboa: Europa-América, 1997.

MUller, G. Complexo agroindustrial e modernização agrária. São Paulo: Hucitec, 1989.

OLSON, M. A lógica da ação coletiva. São Paulo: Edusp, 1999. 201p.

OSTRON, E. El govierno de los bienes comunes: la revoluciósn de lãs instituiciones de acción colectiva. México: Crim, 1990. 383 p.

PÁDUA, S. \& TABANEZ, M.F. Uma abordagem participativa para a conservação de áreas naturais: educação ambiental na Mata Atlântica”. In: CONGRESSO DE UNIDADES DE CONSERVAÇÃO, Curitiba, 1997. Anais. v.2. p. 371-379.

PALMEIRA, M.; LEITE, S. Debates econômicos, processos sociais e lutas políticas: reflexões sobre a questão agrária. Campinas: s.ed., 1996. 65 p.

PATTON, M.Q. Qualitative evaluation and research methods. New York: Sage, 1990. v.1. 
PORTO, M. P. Dilemas da racionalidade: o caso dos efeitos da mídia no comportamento político. In: CAMINO, L.; LHULLIER, L.; SANDOVAL, S.(Org.) Estudos sobre o comportamento político: teoria e pesquisa. Florianópolis: Letras Contemporâneas, 1997. p.39-53.

PRINS, K. (Org.) Taller de investigación participativa: buscando la convergência. Turrialba- Costa Rica: CATIE,1998. 111p.

PUTNAM, R. Comunidade e democracia: a experiência da Itália moderna. Rio de Janeiro: Fundação Getúlio Vargas, 1996. 256p.

QUIVY, R.; CAMPENHOUDT, L.V. Manual de investigação em ciências sociais. Lisboa: Gradiva, 1992. 275 p.

REY, F. La investigación qualitativa en psicologia: rumbos y desafios. São Paulo: EDUC, 1999. 184p.

SANTOS, B. S. Pela mão de Alice: o social e o político na pós-modernidade. São Paulo: Cortez, 1995. 347p.

SAWAIA, B. A consciência em construção no trabalho de construção da consciência. Uma análise psicossocial do processo da consciência de mulheres faveladas participantes de movimentos urbanos de reivindicação social e de um grupo de produção de artesanato. São Paulo, 1987. 2v. Tese (Doutorado) Pontificia Universidade Católica.

SAWAIA, B. A legitimidade subjetiva no processo de participação social na era da globalização. In: CAMINO, L.; LHULlIER, L.; SANDOVAL, S.(Org.) Estudos sobre comportamento político: teoria e pesquisa. Florianópolis: Letras Contemporâneas, 1997. p.149-159.

SAWAIA, B. (Org.) As artimanhas da exclusão: análise psicossocial e ética da desigualdade social. Petrópolis: Vozes, 1999. 156p.

SAWAIA, B. Participação Social e subjetividade. In: SORRENTINO, M. (Coord.) Ambientalismo e participação na contemporaneidade. São Paulo: EDUC; FAPESP, 2001. p.115-134. 
SCHULER, A. E. Florestas sociais: uma experiência de pesquisa-ação com assentamentos rurais na Floresta Nacional de Ipanema. Piracicaba: ESALQ, 1995. 1v.

SEN, A. Desenvolvimento como liberdade. São Paulo: Cia. das letras, 2000. 409p.

SERRES, M. A filosofia mestiça. Rio de Janeiro: Nova Fronteira, 1993. 1v.

SORRENTINO, M. Universidade e educação Ambiental: um estudo de caso. São Paulo, 1995. 1v. Tese (Doutorado) - Faculdade de Educação, Universidade de São Paulo.

SORRENTINO, M. De Tbilissi a Thessaloniki: a educação ambiental no Brasil. In: CASCINO, F.; JACOBI, P.; OLIVEIRA, J.F. Educação, meio ambiente e cidadania: reflexões e experiências. São Paulo. Secretaria do Meio Ambiente; CEAM, 1998. 122p.

SORRENTINO, M.(Coord.) Ambientalismo e participação na contemporaneidade. São Paulo: EDUC; FAPESP, 2001. 229p.

SPOSATI, A. Movimentos utópicos da contemporaneidade. In: SORRENTINO, M. (Coord.) Ambientalismo e participação na contemporaneidade. São Paulo: EDUC; FAPESP, 2001. p.11-39.

TASSARA, E. T. Educação Ambiental, referenciais históricos, teóricos e formação de redes. In: FÓRUM DE EDUCAÇÃO AMBIENTAL, 4.; ENCONTRO DA REDE BRASILEIRA DE EDUCAÇÃO AMBIENTAL, 1., Rio de Janeiro, 1997. Cadernos. Rio de Janeiro: REBEA, 1997. p.206-210.

TASSARA, E. T. Intervenção social e conhecimento científico: questões de método na pesquisa social contemporânea. São Paulo: s.ed., 1996. 1v.

TEIXEIRA, M. C. S. Antropologia, cotidiano e educação. Rio de Janeiro: Imago, 1990. 206p.

THIOLlENT, M. Metodologia da pesquisa-ação. São Paulo: Cortez, 1994. $108 \mathrm{p}$. 
TRIVIÑOS, A N. S. Introdução à pesquisa em ciências sociais: A pesquisa qualitativa em educação. São Paulo: Atlas, 1987.

UNESCO. La educación ambiental: las grandes orientaciones de la Conferência de Tbilisi. Paris: Unesco, 1980.

UNGER, N. M. O encantamento do humano: ecologia e espiritualidade. São Paulo: Loyola, 1991. 94p.

VEIGA, J. E. Nova dinâmica da economia rural. O Estado de São Paulo, 07 mai. 1998.

VÉRAS, M. Exclusão social: um problema brasileiro de 500 anos. In: SAWAIA, B. As artimanhas da exclusão: análise psicossocial e ética da desigualdade social. Petrópolis: Vozes, 1999. p. 27-48.

VIEZZER, M.; OVALlES, O. (Org.) Manual latino-americano de educ-ação Ambiental. São Paulo: GAIA, 1994. 192p. 